\title{
A Phosphoric Acid Fuel Cell Cogeneration System Retrofit to a Large Office Building
}

\section{Technical Note}

\author{
David H. Archer \\ Carnegie Mellon University \\ John G. Wimer \\ United States Department of Energy
}

April 1997

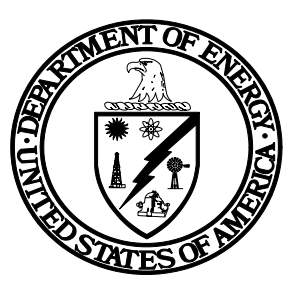

U.S. Department of Energy

Office of Fossil Energy

Federal Energy Technology Center

P.O. Box 880

Morgantown, WV 26507-0880

(304) 285-4764

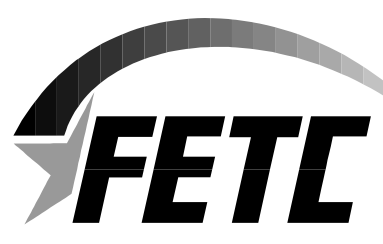

FAX (304) 285-4403/4469

http://www.fetc.doe.gov/ 


\section{Disclaimer}

This report was prepared as an account of work sponsored by an agency of the United States Government. Neither the United States Government nor any agency thereof, nor any of their employees, makes any warranty, express or implied, or assumes any legal liability or responsibility for the accuracy, completeness, or usefulness of any information, apparatus, product, or process disclosed, or represents that its use would not infringe privately owned rights. Reference herein to any specific commercial product, process, or service by trade name, trademark, manufacturer, or otherwise does not necessarily constitute or imply its endorsement, recommendation, or favoring by the United States Government or any agency thereof. The views and opinions of authors expressed herein do not necessarily state or reflect those of the United States Government or any agency thereof. 


\section{Contents}

Page

$1 \quad$ Introduction and Objectives $\ldots \ldots \ldots \ldots \ldots \ldots \ldots \ldots \ldots \ldots \ldots \ldots \ldots \ldots \ldots \ldots$

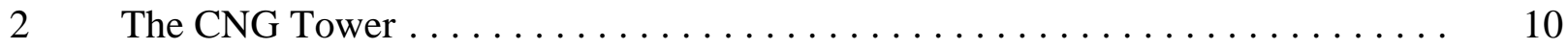

$2.1 \quad$ Existing Energy Supply and HVAC Systems . . . . . . . . . . . 10

2.2 Data Analysis: Requirements for Power, Heating, Air

Conditioning, and Water ......................... 15

3 Design of a Fuel Cell Cogeneration System to Retrofit the CNG Tower ...... 30

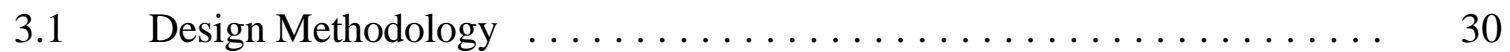

3.2 System Configuration and Component Configuration $\ldots \ldots \ldots \ldots \ldots \quad 30$

3.3 System Capacity Requirements . . . . . . . . . . . . . . . 33

3.4 System Generation and Operation Alternatives . . . . . . . . . . . . . . 35

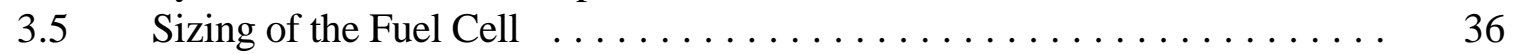

3.6 Sizing of Balance of Plant Components . . . . . . . . . . . . . . 37

4 Cogeneration Systems Operation and Performance Analysis ............. 46

4.1 Results of Technical Performance Calculations ............. 46

Results of Economic Performance Calculations, Annual
Energy Cost Savings . . . . . . . . . . . . . . . . . . . . . . . . . . 50

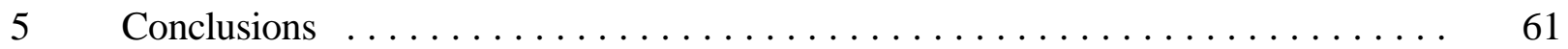

$6 \quad$ Recommendations ..................................... 64

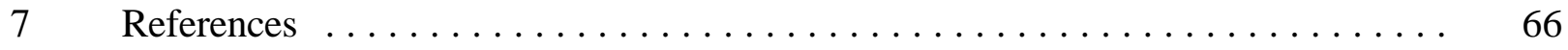

\section{Appendices}

Appendix $\quad$ Page

A Analysis of Heating-Cooling Versus Outside Air Temperature Curves . . . . . 67

B Speculation Concerning ONSI Fuel Cell System Arrangements for

Heat Management .......................... 70

C Generalized Design Procedure for Building Cogeneration Design and

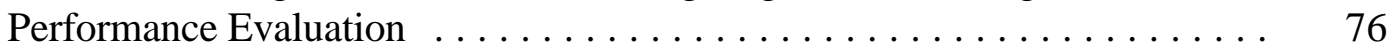

D Detailed Description of System Performance Modeling . . . . . . . . 78 


\section{List of Figures}

Figure

$\underline{\text { Page }}$

1 The CNG Tower in Downtown Pittsburgh, PA . . . . . . . . . . . . 11

2 Typical Floor Plan of the CNG Tower, Lower Floors: $5-19 \ldots \ldots \ldots \ldots$. . . . . 12

3 Typical Floor Plan of the CNG Tower, Upper Floors: $20-30 \ldots \ldots$

4 Current CNG Tower HVAC System . . . . . . . . . . . . . . . . . 14

$5 \quad$ HVAC Delivery System for a Floor in the CNG Tower . . . . . . . . . . . . 14

$6 \quad$ Comparison of Daily Average Outside Air Temperature Data Sets for '93 . . . . 17

$7 \quad$ Monthly Power Demands of the CNG Tower in '93 . . . . . . . . . . . . . 17

8 Weekday Power Demand of the CNG Tower: February '93 . . . . . . . . 18

9 Power Demand of the CNG Tower: February ' $93 \ldots \ldots \ldots \ldots \ldots \ldots \ldots$

10 Non-Air Conditioning Power Demand of the CNG Tower: 17 Weekdays

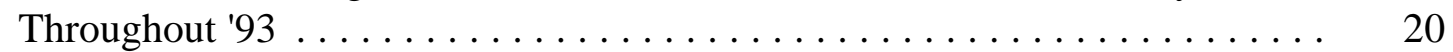

11 Non-Air Conditioning Power Demand of the CNG Tower: 8 Saturdays

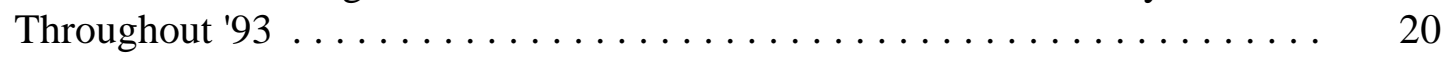

12 Non-Air Conditioning Power Demand of the CNG Tower: 8 Sundays

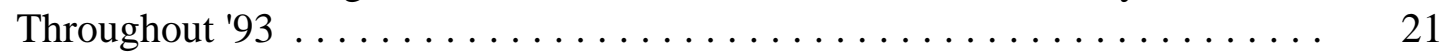

13 Monthly Natural Gas Use of the CNG Tower: '93 Space Heating . . . . . . . . 21

14 Effect of Outside Air Temperature on CNG Tower Natural Gas Usage . . . . . . 23

15 Hourly Air Conditioning Demand in the CNG Tower: 31 August $93 \ldots 23$

16 Air Conditioning Rate Proportional to Chilled Water Supply-Return

Temperature Difference: 31 August $93 \ldots \ldots \ldots \ldots \ldots . \ldots \ldots$

17 Hourly Effect of Outside Air Temperature on Air Conditioning Demand . . . . . 24

18 Effect of Outside Air Temperature and Relative Humidity on Weekday

Air Conditioning Demand $\ldots \ldots \ldots \ldots \ldots \ldots \ldots \ldots \ldots \ldots$

19 Effect of Outside Air Temperature and Relative Humidity on the CNG

Tower's Weekday Heating and Air Conditioning Rates . . . . . . . . . . . 27

Air Conditioning Via the Water-to-Water Heat Exchanger and Cooling Tower .

Cogeneration System Configuration for Fuel Cell Retrofit of the CNG Tower . . 31

Average Non-A.C. Weekday Demand Met by the Average Load System . . . . . $\quad 38$

Battery Storage Profile During an Average Weekday . . . . . . . . . . . . 38

ONSI PC25 Fuel Cell Reject Heat Availability . . . . . . . . . . . . . . . . . . . 39

Weekday Air Conditioning Supplied by Peak Load System Absorption Chiller . 42

Weekend Air Conditioning Supplied by Peak Load System Absorption Chiller . $\quad 42$

27 Weekday Air Conditioning Supplied by Average Load System Absorption

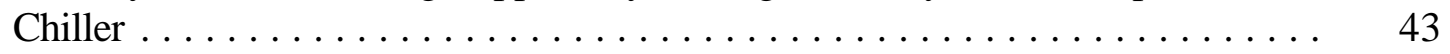

28 Weekend Air Conditioning Supplied by Average Load System Absorption

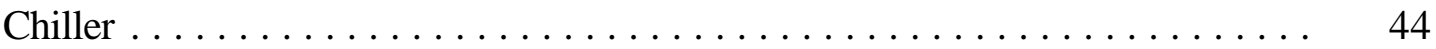

29 Purchases from the Electric Utility by the Existing and Retrofit Systems . . . . .

30 Fraction of Annual Space Heating and Air Conditioning Supplied from

Fuel Cell Heat . . . . . . . . . . . . . . . . . . . . . 49

31 Purchases from the Gas Utility by the Existing and Retrofit Systems . . . . . . 50

32a Annual Energy Cost Savings for the CNG Tower: Peak Load System . . . . . 51

32b Annual Energy Cost Savings for the CNG Tower: Average Load Systems . . . 51 


\section{List of Figures}

(Continued)

Figure

Page

32c Annual Energy Cost Savings for the CNG Tower: Base Load System . . . . . $\quad 52$

33a Conditions for Economic Feasibility of the Peak Load Fuel Cell Retrofit

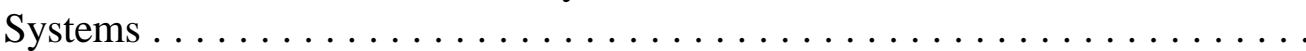

33b Conditions for Economic Feasibility of the Average Load Fuel Cell Retrofit

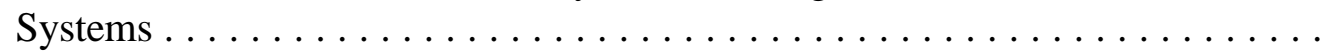

33c Conditions for Economic Feasibility of the Base Load Fuel Cell Retrofit

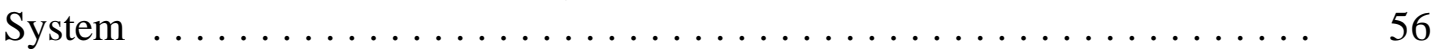

34a Annual Energy Cost Savings from Absorption Chillers: Peak Load System . . . $\quad 58$

34b Annual Energy Cost Savings from Absorption Chillers: Average Load

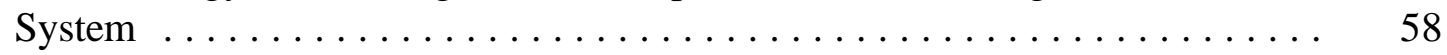

35 Primary Energy Use of the Existing and Retrofit Systems $\ldots \ldots \ldots \ldots \ldots$

A-1 Heat Balance Representation of the HVAC Arrangements for a Floor of the CNG Tower ............................... 68

A-2 CNG Tower Heating-Cooling Curve Analysis . . . . . . . . . . . . . . . . 69

B-1 Possible Fuel Cell Power System Flow Diagram with Heater, Cooler

(Half Exchanger) Units . . . . . . . . . . . . . . . . . . . . 71

B-2 T-Q Diagram for Heat Sources and Sinks in the Fuel Cell Power System . . . . . 71

B-3 T-Q Diagram for Heat Exchange in the Heat Recovery Exchanger of the

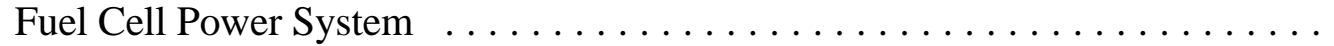

\section{List of Tables}

Table

1 Characteristics of the CNG Tower's Non-A.C. Power Demand . . . . . . . . . 19

2 CNG Tower Fuel Cell Cogeneration System Equipment Performance Data . . . 32

3 CNG Tower Fuel Cell Cogeneration System Capacity Requirements . . . . . . . 35

$4 \quad$ Annual Performance Summary for Existing and Fuel Cell Retrofit Systems . . . 47

$5 \quad 1995$ Electric Utility Rate Structure for CNG Tower . . . . . . . . . . . . . . 52

B-1 Low Temperature Fuel Cell Flow Diagram for External Methane Reforming . . . 72

D-1 Modeling Equations for Fuel Cell Retrofit Systems without an Absorption

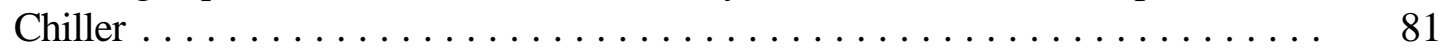

D-2 Modeling Equations for Fuel Cell Retrofit Systems with an Absorption Chiller . . . . . . . . . . . . . . . . . . . . . . . . . . . . . 


\section{Acknowledgments}

We extend our thanks to Mark J. Duffy, Lead Engineer for Lincoln Property Company, for his significant assistance in providing us with operating data and system descriptions for the CNG

Tower. We thank also the ONSI Corporation who provided information on their 200-kilowatt ONSI PC25C phosphoric acid fuel cell power system. 


\section{Introduction and Objectives}

The U.S. Department of Energy's Federal Energy Technology Center (FETC) sponsors research and development applied to energy systems that achieve high efficiency, economy, and environmental performance while using domestic fossil fuel supplies. Fuel cell systems are among the most promising electric power generation technologies that FETC is currently developing.

FETC is also interested in the commercialization of fuel cell power systems so that the potential benefits of the technology might be available to the U.S. public. Commercialization requires the existence of applications and markets for fuel cell systems. One possible early area of application is natural gas fueled cogeneration systems for commercial installations such as hospitals, hotels, and office buildings. In such a cogeneration system, a fuel cell would produce electric power and the associated waste heat would provide space heating, air conditioning (by means of absorption refrigeration), and water heating. Fuel cell systems are readily adapted to such applications.

- The power output of available developmental fuel cell power systems approaches the power requirements of such installations.

- The proportions of electrical and thermal energy produced by such fuel cell systems match the requirements of many such installations.

- The high energy efficiency of such systems can reduce energy costs.

- The atmospheric emissions of nitrogen oxides $\left(\mathrm{NO}_{\mathrm{X}}\right)$, sulfur dioxide $\left(\mathrm{SO}_{2}\right)$, carbon monoxide $(\mathrm{CO})$, and unburned hydrocarbons are negligible.

- Locating fuel cell systems in urban areas can assist in meeting increased power requirements without the installation of additional transmission and distribution lines.

- The building's heating, ventilating, and air conditioning (HVAC) system can serve as the heat rejection component of the fuel cell power system. This integration of the fuel cell with the HVAC system can result in a capital cost which is less than the combined costs of the individual systems. Engineering effort will be required initially, however, to determine how this integration might most effectively be achieved.

In addition the fuel cell, when integrated with the utility grid, diesel engine generators, or batteries, can serve as the significant component of an uninterruptible power supply. And fuel cell power quality is ideal for electronic equipment, e.g., computers, which are sensitive to the harmonics and voltage fluctuations common in power supplied by the utility grid.

Arthur D. Little (1) predicted that office buildings will be the second largest sector in the commercial building market for fuel cell cogeneration. Although the energy demands of hospitals and hotels are more favorably adapted to cogeneration (they are more nearly constant throughout the course of each day), a greater quantity of fuel cell capacity will be installed in office buildings 
due to their much larger numbers. Seventeen percent of all commercial buildings are office buildings. In a report prepared for the Gas Research Institute (2), Lawrence Berkeley identified large, 12-hour office buildings as one of six high priority candidates for cogeneration, noting that large office buildings are, in general, the fastest growing sector in all major utility service areas across the country.

The main objective of this study was to explore this early market opportunity for fuel cell systems in large office buildings and to determine the conditions under which they might compete with the alternative of purchased power. Other objectives were:

- To identify and to provide solutions for problems encountered in adapting a fuel cell cogeneration system to a large office building;

- To discover and to take advantage of opportunities for improving the performance of such systems;

- To provide first a specific example of, and then a general procedure for, the design and performance evaluation of a fuel cell cogeneration system for a large office building;

- To develop conclusions from this specific analysis that are applicable to large office buildings across the United States; and

- To provide an example that can be used to validate market projections.

To accomplish these objectives, several specific fuel cell cogeneration systems adapted to the needs of a specific building were designed and evaluated. This process involved six steps.

- The building's current HVAC system was characterized. The building's use of power, heating, and air conditioning throughout the year 1993 were determined from information compiled by a data acquisition system or logged daily by building operators. (Power use varied throughout a day; and differed on weekends from weekdays. Heating, determined from the daily usage of natural gas, varied with the outside air temperature; air conditioning varied with both the outside air temperature and humidity.)

- The requirements of the building for power, heating, air conditioning, and heat rejection were established for various cogeneration systems, based on daily power use profiles and weather data. Systems which provided for the peak power, for the average power, and for the minimum, or base, power demands of the building were considered. In every case, the HVAC system was sized to meet the peak heating and air conditioning needs of the building determined either from temperature and humidity extremes or from the 1993 data.

- A specific fuel cell system, ONSI Corporation's PC25C phosphoric acid fuel cell, was characterized in terms of the quantity of heat flow available and its temperature level, based on the power output of the system. Available absorption refrigeration systems were also characterized in terms of the quantity and temperature level of the heat flow required to achieve a given cooling rate by a hydronic, cooled water, air conditioning system. 
- Various fuel cell cogeneration systems were configured. The various cogeneration system components were sized; and their interconnection with the existing building heating, air conditioning, and heat rejection systems, indicated -- the fuel cell with its heat recovery/ rejection system, the absorption refrigeration air conditioning unit; and the existing hot water boilers, vapor compression refrigeration units, and cooling tower.

- The annual energy costs (natural gas fuel and possibly purchased electrical energy) for providing power, heat, and air conditioning to the building were calculated for the various cogeneration systems. These costs were compared with the energy costs for operating the building with its existing system. The energy cost savings provided by the various cogeneration systems were used to provide estimates of what capital costs for each of these systems might be economically justified.

All these steps in the work are described in detail in the subsequent sections of this report. 


\section{The CNG Tower}

To illustrate clearly the design, evaluation and performance of a fuel cell cogeneration system, a specific application, the CNG Tower shown in Figure 1, was chosen as an example. Located in downtown Pittsburgh, the modern, 32-story office building has a total floor area of 623,000 square feet, the seventh largest in the city. Typical floor layouts are shown in Figures 2 and 3. On average, there are around 3,000 people in the CNG Tower during office hours.

The primary occupant of the building, $\mathrm{CNG}$, is a distributor of natural gas fuel and an investor in power generation and cogeneration facilities. The company is interested in the installation of cogeneration systems and in fuel cells and their application. The CNG Tower manager, Lincoln Property Management, has proved to be helpful and cooperative in studies directed toward understanding and improving its operation.

\subsection{Existing Energy Supply and HVAC Systems}

Lincoln Property has provided information on the building's energy, power and natural gas supplies, and HVAC systems so that the design and performance of a retrofitted fuel cell cogeneration system might realistically be considered.

The building presently purchases electricity used for lighting, ventilation, air conditioning, office equipment, water heating, and elevator operation; and natural gas used for space heating. The CNG Tower currently relies on an oil-fired diesel engine generator to provide $700 \mathrm{~kW}$ of backup power for the building's security and fire alarm systems, emergency lighting, fire pumps, smoke evacuation fans, and elevators. In addition, some tenants require backup power for various applications, such as telecommunications equipment.

The HVAC system of the building is equipped with two, 250-horsepower (hp) [2450kilowatt $(\mathrm{kW})$ thermal] gas-fired boilers and two, 750-ton (2640-kW thermal) electrically driven vapor compression water chillers, shown in Figure 4. These HVAC prime movers provide the building with full redundancy; the CNG Tower can operate with a single boiler and a single chiller. Figure 5 shows the HVAC arrangements for a typical floor in the CNG Tower. The HVAC system is a four pipe hydronic system with individual supply and return lines for heated and for chilled water: the boilers provide $180^{\circ} \mathrm{F}$ hot water to heating fan coils located over the windows on each floor, and the chillers supply $45^{\circ} \mathrm{F}$ cold water to cooling coils located at the inlet to the central air circulation fan on each floor. Such a hydronic thermal distribution system is readily adaptable to cogeneration.

Air Flow. Fresh air is forced down a common, central shaft in the building by a ventilating fan located on the roof. Next, the fresh air passes through hand-adjusted louvers on each floor of the building into a plenum room where it mixes with recirculated air in the proportion of 15 percent fresh to 85 percent recirculated. The air mixture passes through a filter, then over a cooling 


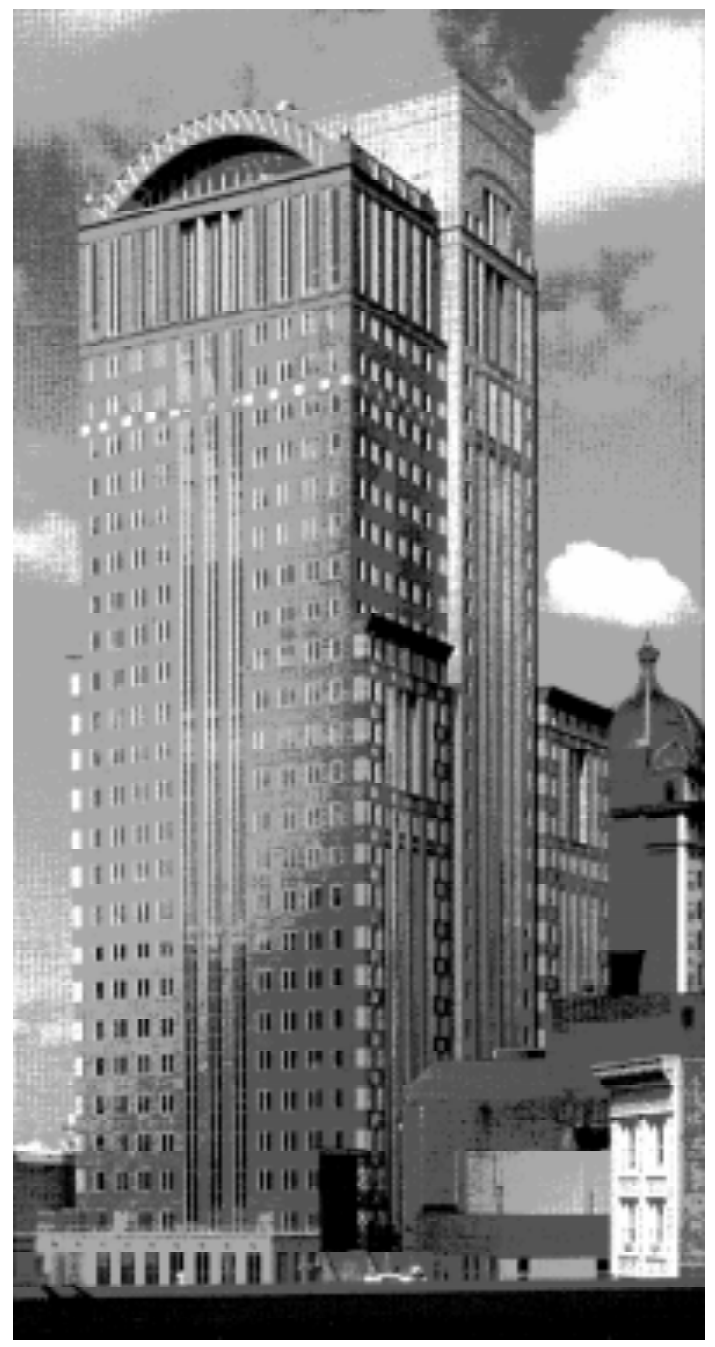

- 625 Liberty Avenue; Pittsburgh, PA

- 32-story office building - 7th tallest building in downtown

- 623,000 gross square footage

- Approximately 3,000 weekday occupants

- Completed in 1987

Figure 1. The CNG Tower 


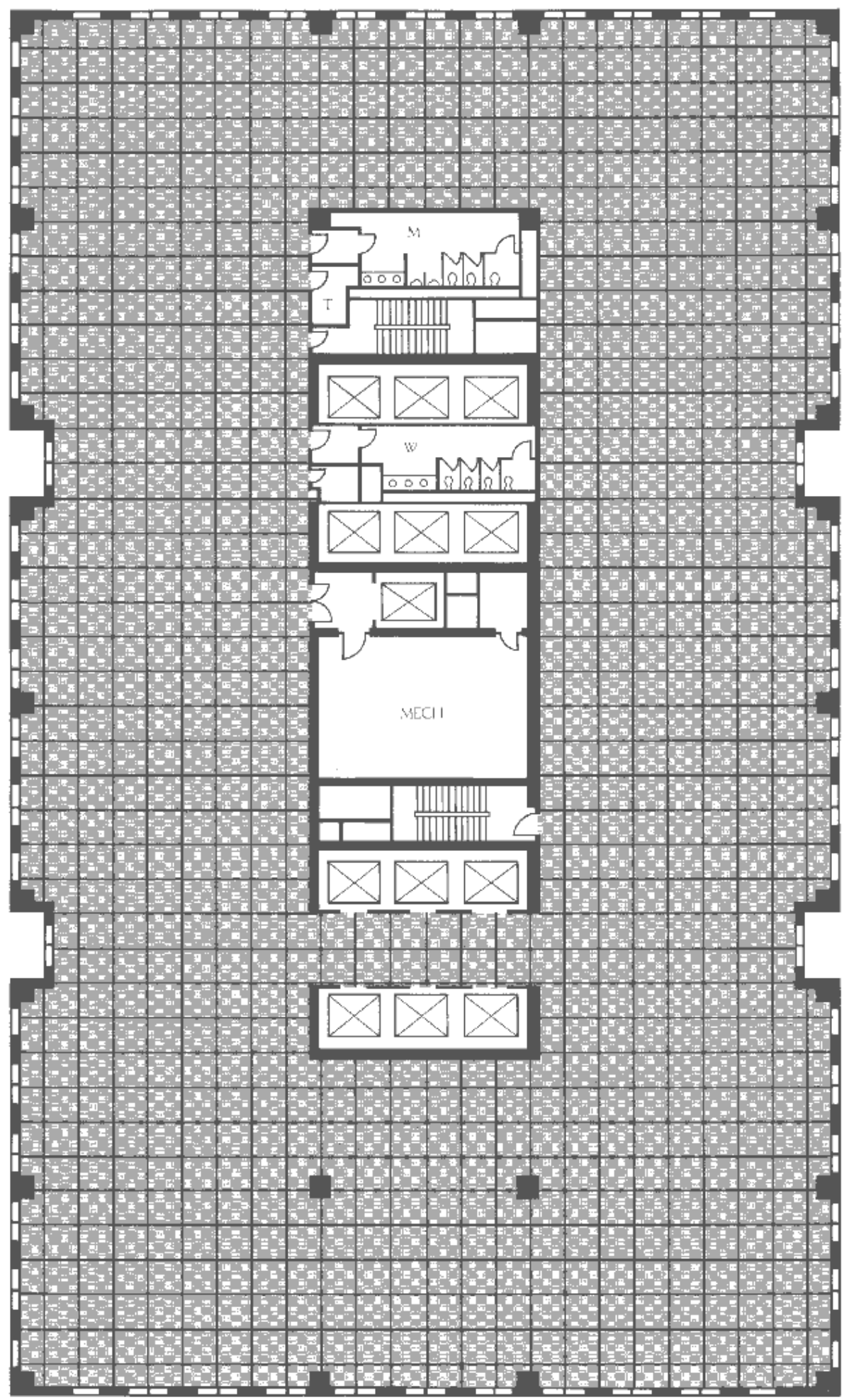

Figure 2. Typical Floor Plan of the CNG Tower, Lower Floors: 5-19 


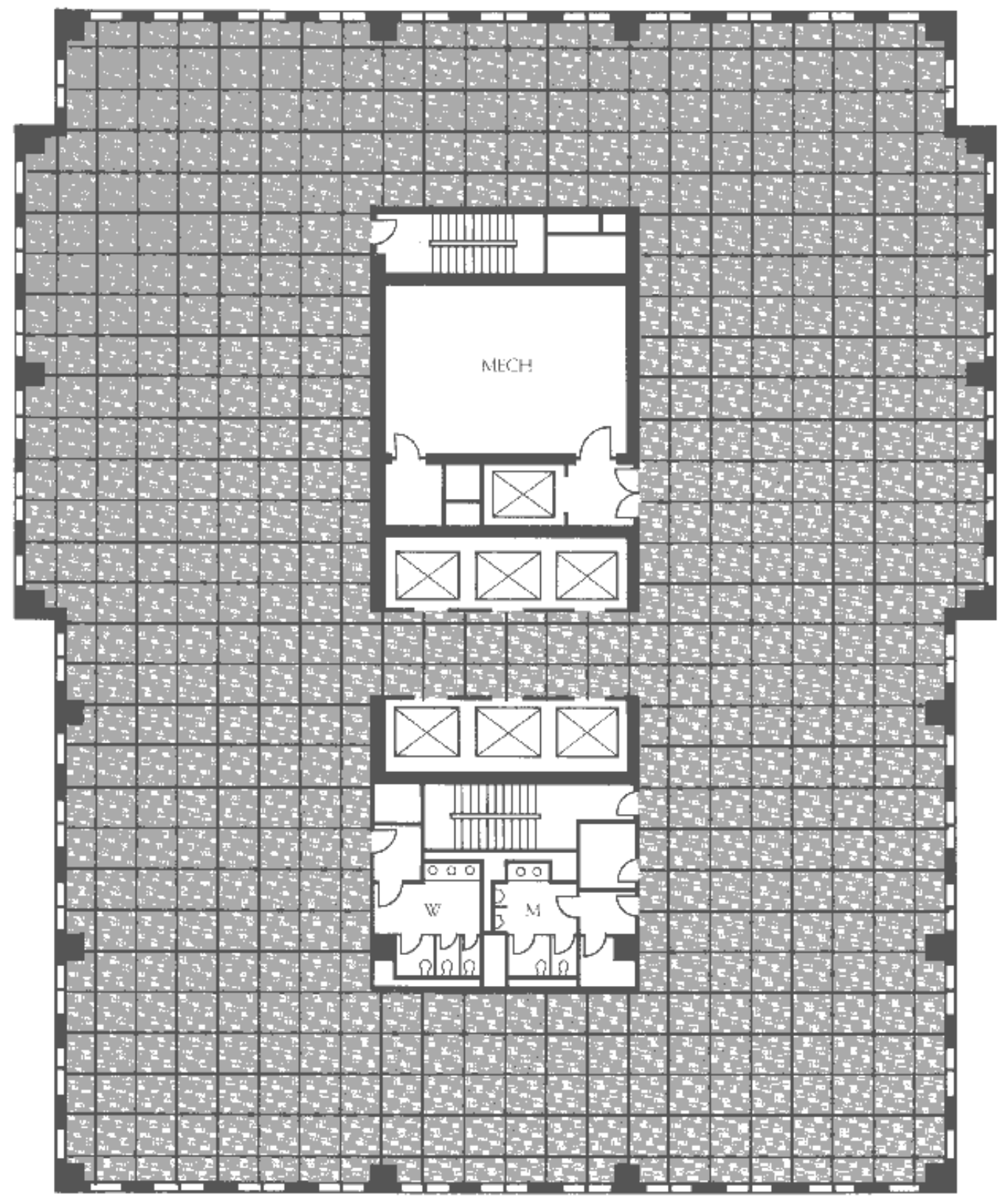

Figure 3. Typical Floor Plan of the CNG Tower, Upper Floors: 20-30 


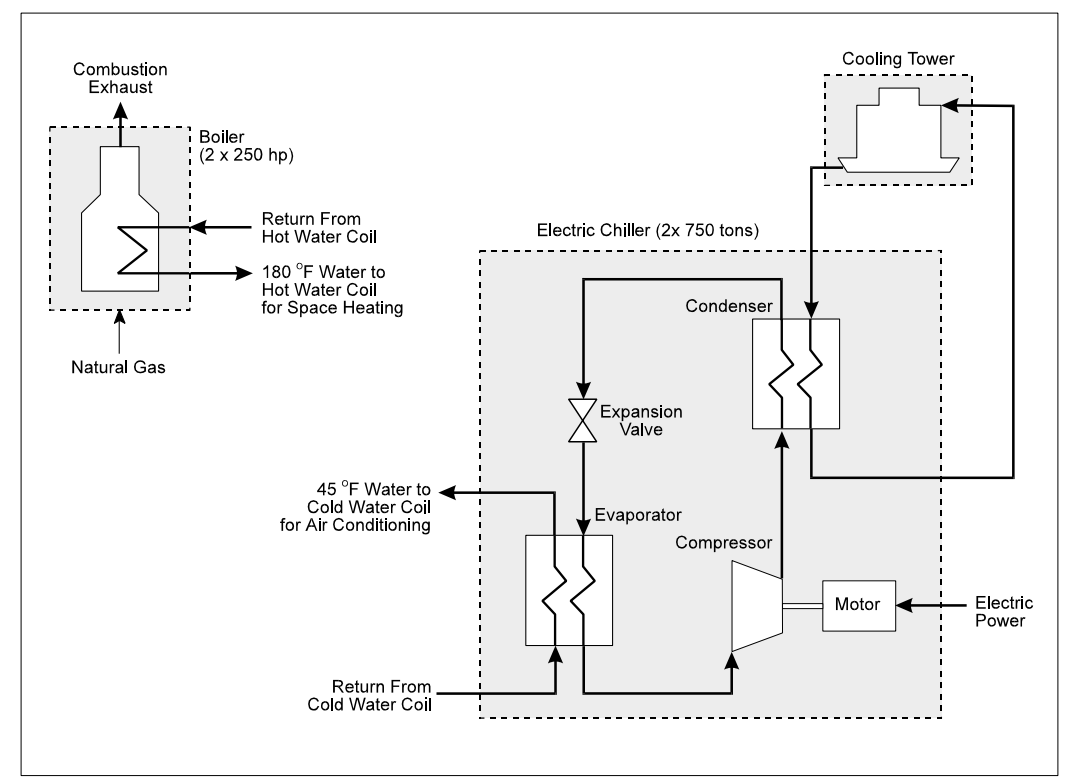

Supplies Hot and Cold Water to HVAC Delivery System

Hot water: $2 \times 2450 \mathrm{~kW}$ heating capacity

Cold water: $2 \times 2640 \mathrm{~kW}$ cooling capacity

\section{Figure 4. Current CNG Tower HVAC System}

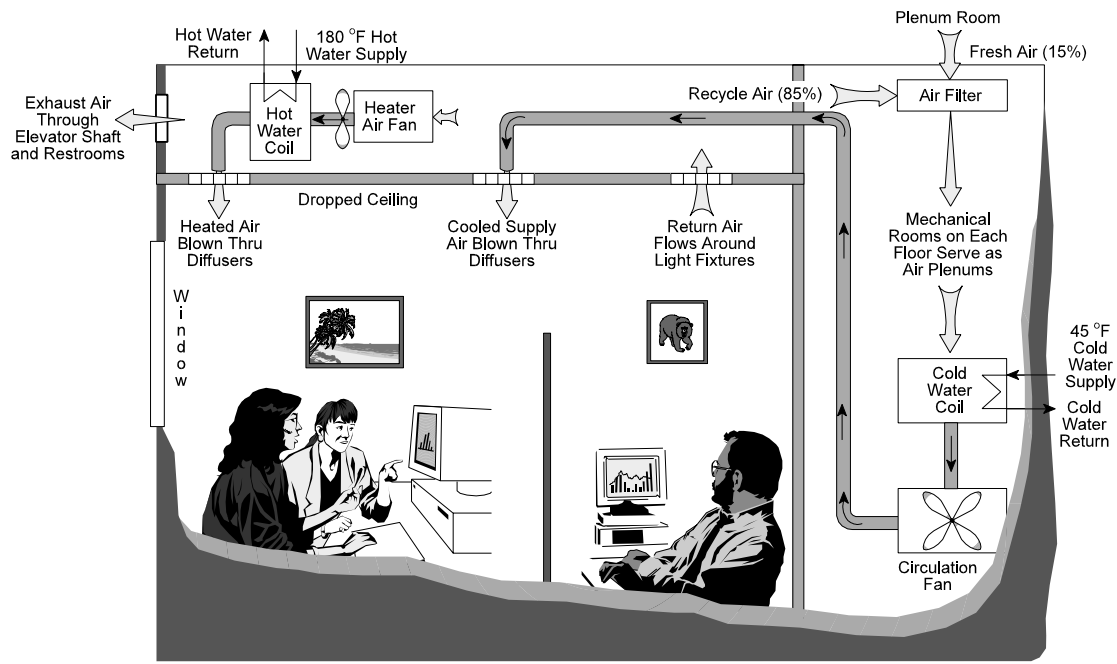

Space Heating and Air Conditioning Require Hot and Cold Water

Space heating

Above each window, circulated air is forced down over hot water heating coils, (constant temperature, variable flow water).

Air conditioning: coil (constant temperature, variable flow water)

Ventilation:

Total air circulation rate is 20,000 CFM on each low-rise floor and 15,000 CFM on each high-rise floor. Air is exhausted through bathroom vents and elevator shafts.

Figure 5. HVAC Delivery System for a Floor in the CNG Tower Four Pipe, Fan Coil, Hydronic Thermal Distribution System 
coil (through which chilled water flows when the air conditioning system is activated), and finally through a ventilation fan and into air ducts which feed ceiling mounted diffusers distributed over the floor area. Return air from each floor flows through openings around the lighting fixtures into the space over the false ceiling, through which it flows back to the plenum room. The total air circulation rate is 20,000 cubic feet per minute (CFM) on each low-rise floor and 15,000 CFM on each high-rise floor. To balance the fresh air intake, air is exhausted from each floor of the building through rest room vents into a common air shaft, and through other vents into the elevator shafts. To conserve energy, the ventilation fans on each floor customarily operate only from 6:00 a.m. to 6:00 p.m. on weekdays and from 7:00 a.m. to 1:00 p.m. on Saturday. The fans are turned off all day each Sunday.

Space Heating. Space heating air is provided when called for by small air recirculation fans and heating coils located above the ceiling over each window. Each small fan operates around the clock in response to the local thermostat, drawing air from the space above the false ceiling and passing it through a filter, across a heating coil supplied with hot water, and into the room through special diffusers located above the windows. Similarly, the valve adjusting the flow of hot water from the supply line through the coil to the return line operates in response to the local thermostat. Two natural gas-fired, $250 \mathrm{hp}$ Cleaver Brooks boilers (actually water heaters) supply all the coils with around 500 gallons per minute, GPM, of $180^{\circ} \mathrm{F}$ hot water. The heating requirements of the building can, in general be met by the operation of one of these boilers. In the coldest weather, the flow rate of hot water is increased to 1000 GPM by turning on a second pump (there are three identical pumps) and the water temperature is increased to $200{ }^{\circ} \mathrm{F}$.

Air Conditioning. Air is cooled as it passes over a cooling coil in each floor's plenum room, transferring heat to the chilled water flowing through the coil. The flow of chilled water to each individual floor's cooling coil is controlled by that floor's thermostat. The supply temperature of the chilled water is maintained constant by two of three available circulation pumps as the conditions outside and inside the building vary. Typically, 874 GPM of chilled water is supplied to the coils at $45^{\circ} \mathrm{F}$ by just one of the two 750-ton vapor compression York chillers. During extremely hot weather, the chiller supplies the water to the coils at $42^{\circ} \mathrm{F}$. When the outside temperature is cool enough, neither chiller is operated. Instead, the cooling coil water is chilled in a water-towater heat exchanger by cold water that circulates through the roof-mounted cooling tower. When a chiller is operating, water from the cooling tower is also used in its condenser.

\subsection{Data Analysis: Requirements for Power, Heating, Air Conditioning, and Water}

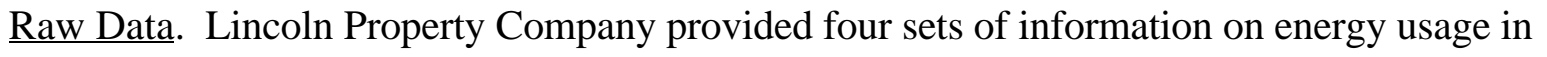
the CNG Tower throughout the year 1993:

- Daily meter readings for electric, gas, water, and cooling tower makeup and blow down;

- Monthly electric and gas bills and quarterly water bills with meter readings and rate information;

- Detailed electrical trend logs - average power demands over each 15-minute interval; and 
- Detailed chiller logs - power input and cooling output for the air conditioning system at 5 -minute intervals.

The electric and gas meter readings reported in the monthly and quarterly billings check those that appear in the daily meter readings. The reported water use in cooling tower make up closely approximates the water evaporation rate estimated from heat removal and power consumption in the air conditioning system.

Weather data were obtained from the U.S. Weather Bureau. They consist of hourly temperature and humidity readings. Figure 6 shows the reported air temperature at the CNG Tower as a function of the temperature recorded by the U.S. Weather Bureau at the Greater Pittsburgh International Airport. As expected, there is a strong correlation between these two temperatures; the temperature at the CNG Tower, however, is about $2-7^{\circ} \mathrm{F}$ higher than that at the Airport; this temperature difference decreases as the temperature increases.

The raw data described above were used to characterize the building's demands for electricity, space heating, and air conditioning throughout 1993. A correlation of the CNG Tower's total daily space heating demand (tons) with the daily average outside air temperature was based on the daily gas meter readings for the months of January, February, and November. Data on power use during February were used to characterize the hourly demand throughout the week in the absence of air conditioning. To characterize further the CNG Tower's electrical and air conditioning demands, 33 days in three categories; 17 weekdays, 8 Sundays, and 8 Saturdays; were sampled for detailed analysis. For each of these 33 days, the following data were analyzed:

- The hourly air conditioning demand (tons), calculated from the chiller logs;

- The hourly electric demand $(\mathrm{kW})$, calculated from the electrical trend logs;

- The hourly electric demand of the electric chillers, calculated from the chiller logs.

Monthly Power Demands With AC. Figure 7 shows the average power demand and the 15-minute rolling peak of each month in 1993. These are relatively constant, increasing slightly in the months of July, August, and September due to chiller operation. The peak demand during these months is 500 to $600 \mathrm{~kW}$ greater than during the winter months. The overall peak power demand in 1993, including power for air conditioning, was $2790 \mathrm{~kW}$, occurring on August 16.

Non-Air Conditioning Power Demand. The electrical trend logs provide 15-minute running averages of the power demand reported at 15-minute intervals. Figures 8 and 9 show values of this running average hourly usage throughout a number of days in February 1993 during which no electricity was used for air conditioning. For weekdays, the electric demand profile does not vary significantly from day to day (Figure 8); however, Saturdays and Sundays have their own distinct profiles due to reduced building occupancy (Figure 9). On weekdays, building lighting and ventilation customarily operate from 6:00 a.m. to 6:00 p.m.; on Saturday, from 7:00 a.m. to 1:00 p.m.; 


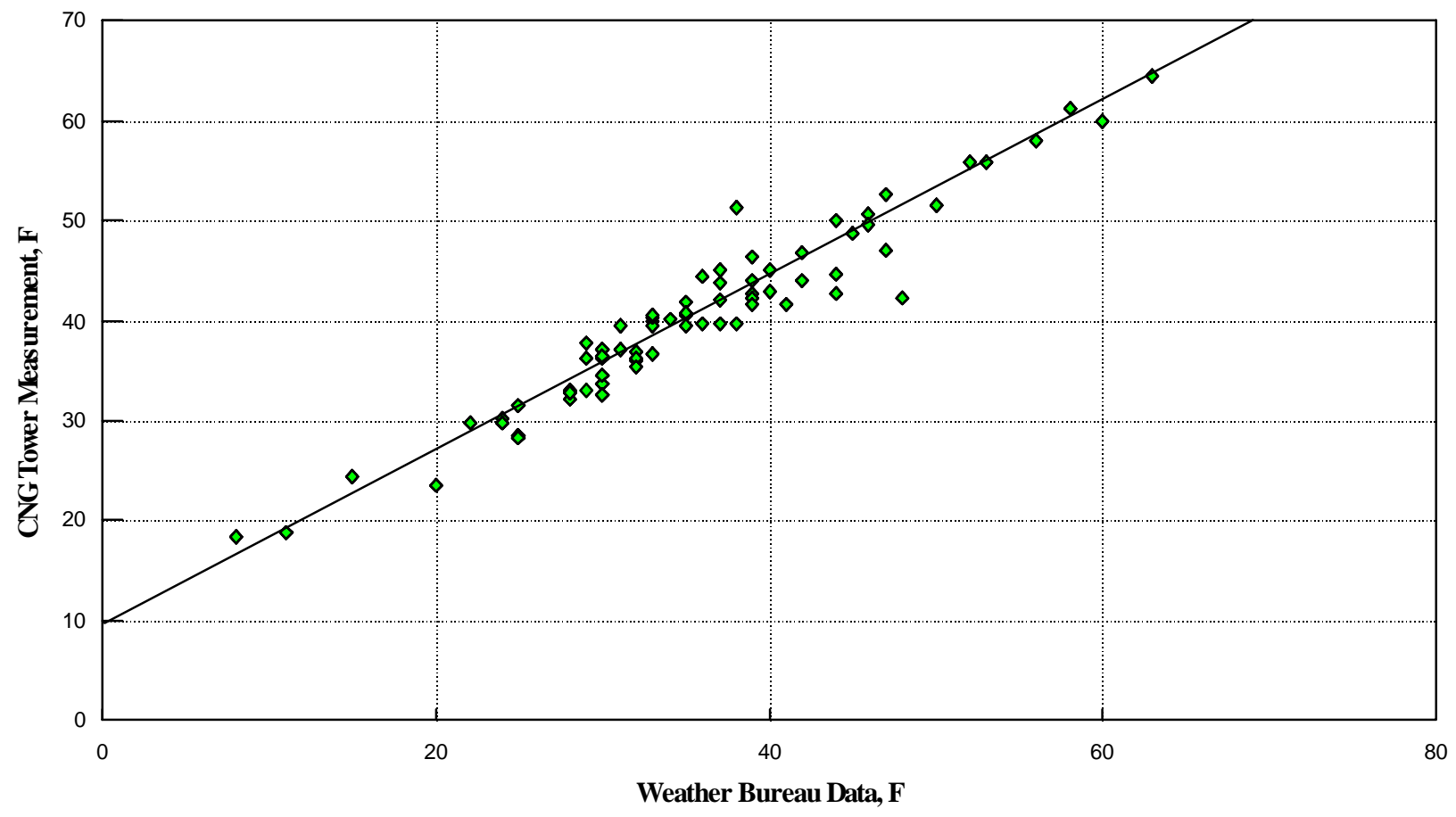

Figure 6. Comparison of Daily Average Outside Air Temperature Data Sets for Data from Jan., Feb., and Nov. 1993

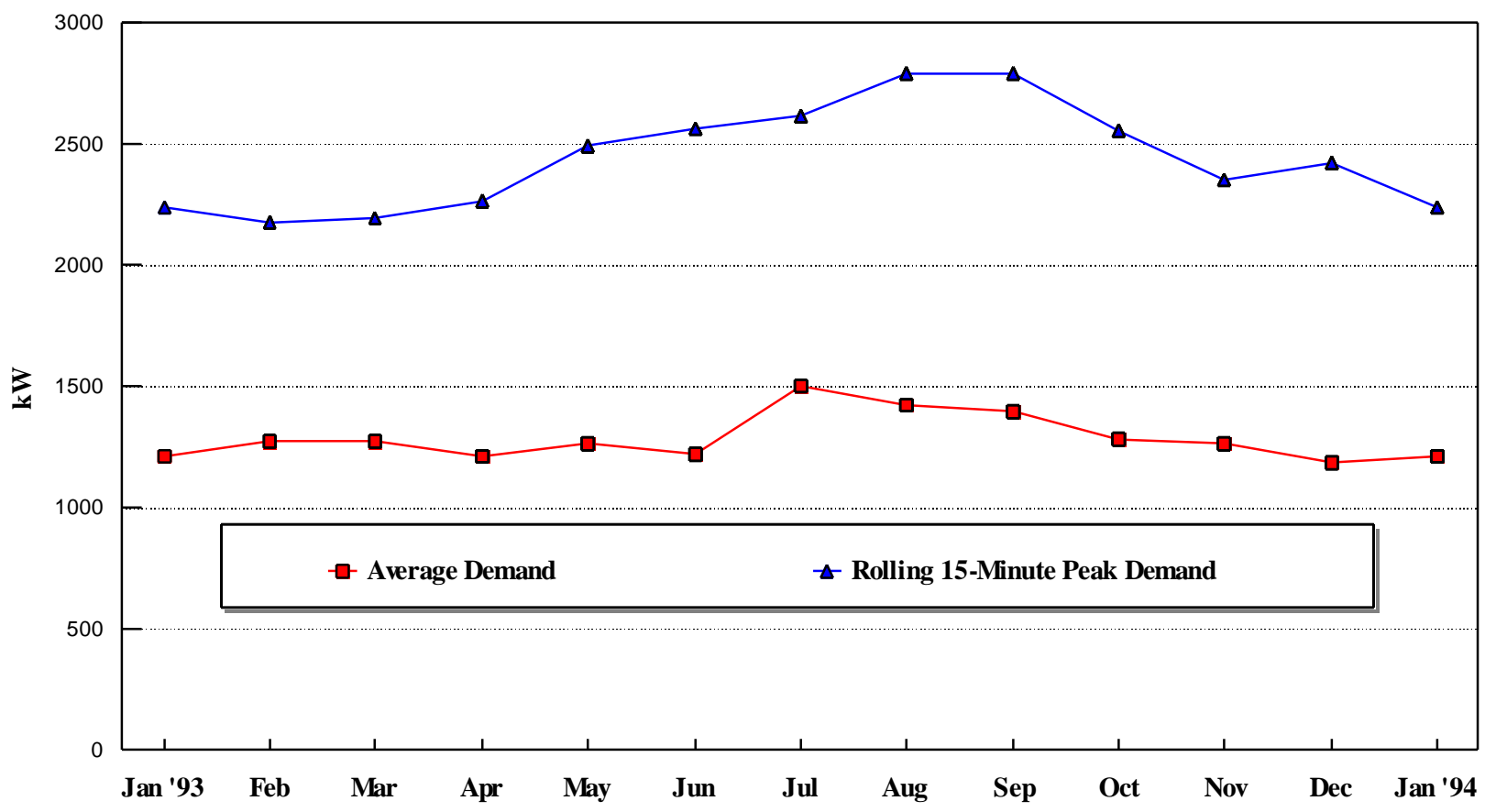

Figure 7. Monthly Power Demands of the CNG Tower in 1993 


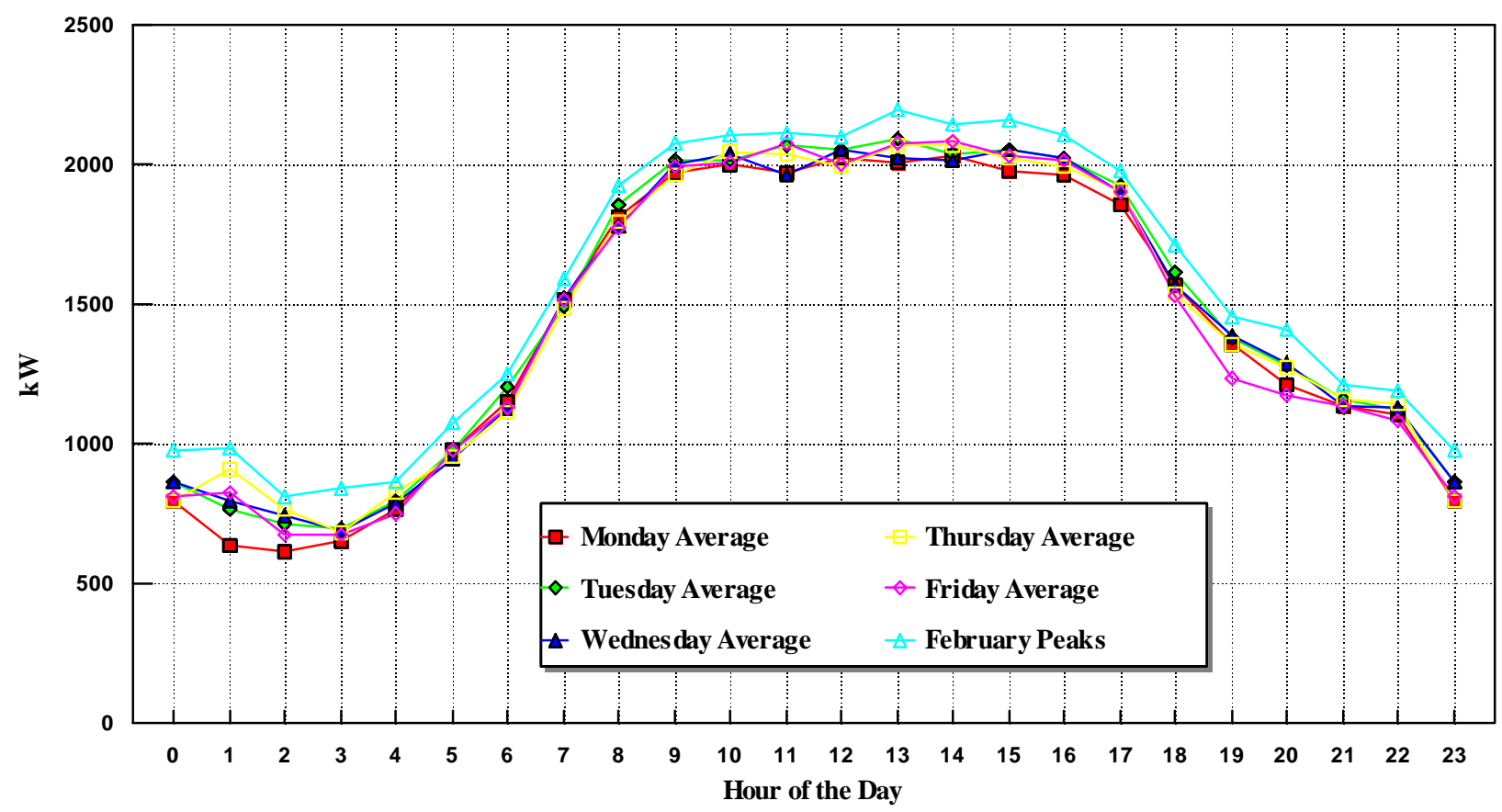

Figure 8. Weekday Power Demand of the CNG Tower February 1993

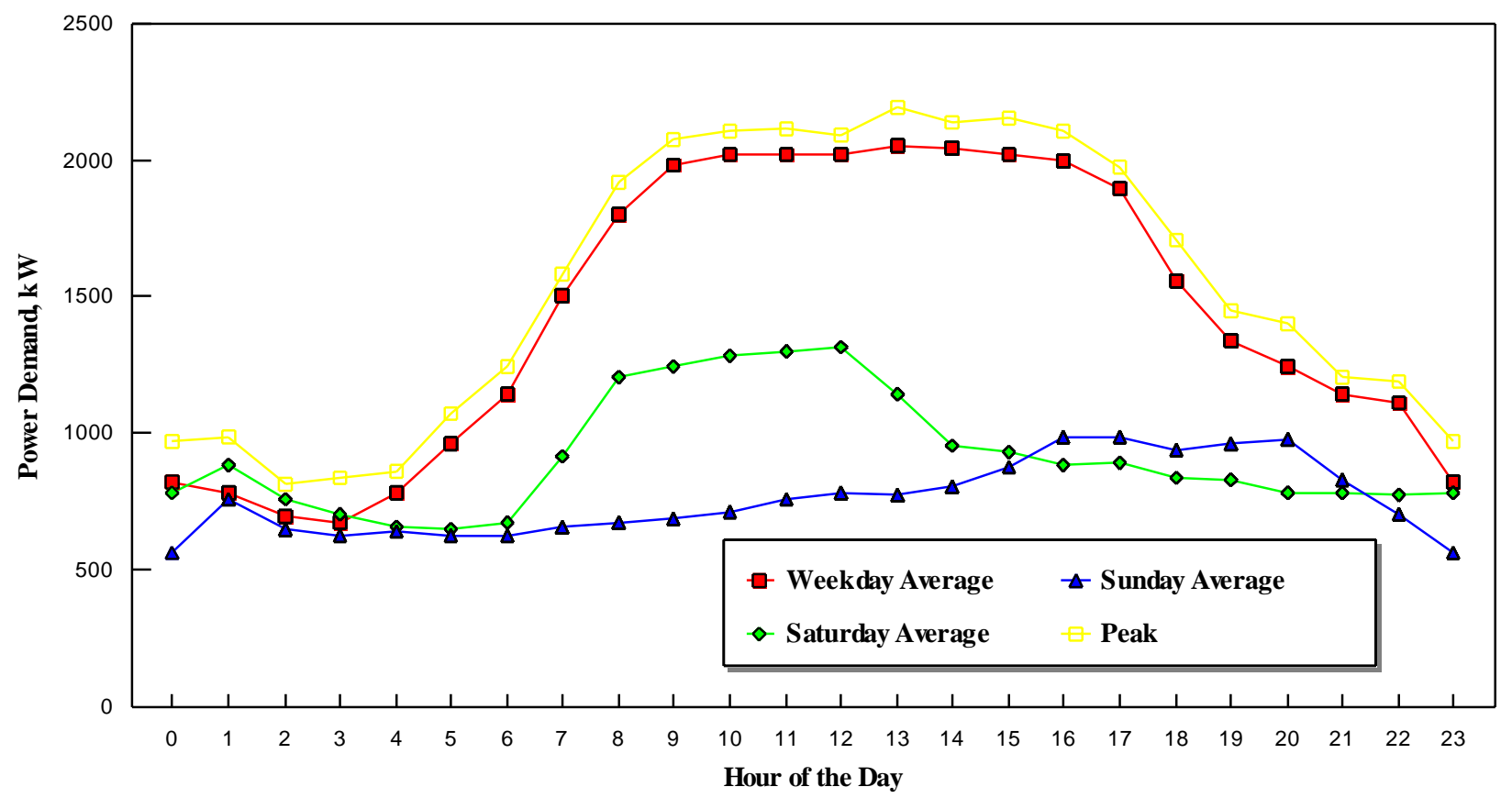

Figure 9. Power Demand of the CNG Tower February 1993 
and on Sunday the ventilation is turned off and the lights are turned on only as needed by the afternoon cleaning staff.

Since no power was consumed by the CNG Tower's electric chillers in February 1993; Figures 8 and 9 reflect the CNG Tower's non-air conditioning (non-a.c.) demand. During warmer months, however, the electric chillers caused substantial fluctuations in the total demand for electricity. For each of 33 days sampled throughout 1993, this seasonal variation in their electric demand profile was eliminated, generating three averaged, non-a.c. demand profiles as shown in Figures 10, 11, and 12. This was accomplished by subtracting the hourly electric chiller demand from the total hourly electric demand. This analysis confirmed that the CNG Tower's non-a.c. daily electric demand profiles did not vary seasonally. Therefore, it was concluded that the nona.c. electric load could be accurately modeled throughout an entire year by employing the averaged demand profiles for weekdays, Figure 10; Saturdays, Figure 11; and Sundays, Figure 12. The non-a.c. load characteristics presented in Table 1 are based on the data shown in these three demand curves.

Table 1. Characteristics of the CNG Tower's Non-A.C. Power Demand

\begin{tabular}{||c|c|c|c||}
\hline Parameter & Sunday & Saturday & Weekday \\
\hline \hline $\begin{array}{c}\text { Peak of (non-averaged) } \\
\text { Hourly Demands, kW }\end{array}$ & 1410 (July 11) & 1400 (Aug. 28) & 2220 (Aug. 16) \\
\hline $\begin{array}{c}\text { Average Daily } \\
\text { Demand, kW }\end{array}$ & 750 & 890 & 1410 \\
\hline $\begin{array}{c}\text { Minimum Demand of } \\
\text { Averaged Hourly Profile, } \mathrm{kW}\end{array}$ & 557 & 603 & 565 \\
\hline
\end{tabular}

Space Heating. Readings from a single gas meter are reported daily. These readings provide data on the flow of natural gas to the two Cleaver Brooks boilers. The boilers supply hot water to the heating system of the building. No gas is used in providing hot water for domestic use in the building; electric heating is used for this purpose. Data on the hourly gas usage are not available. A search through the boiler operation logs would be required to determine the variability in hourly gas usage and its correlation with outside air temperature. Information on hourly gas usage and on the effective heat capacity of the building and its contents could be required to determine how the waste heat rejected from the fuel cell power system can most effectively be used in space heating.

Figure 13 shows the monthly gas usage for 1993. In general the heating system is in full operation during the months of November, December, January, February, and March; partial operation during April and October; and shut down during May, June, July, August, and September. The data indicate that on some spring and early summer days both heating and cooling are required to provide comfort in the building. 


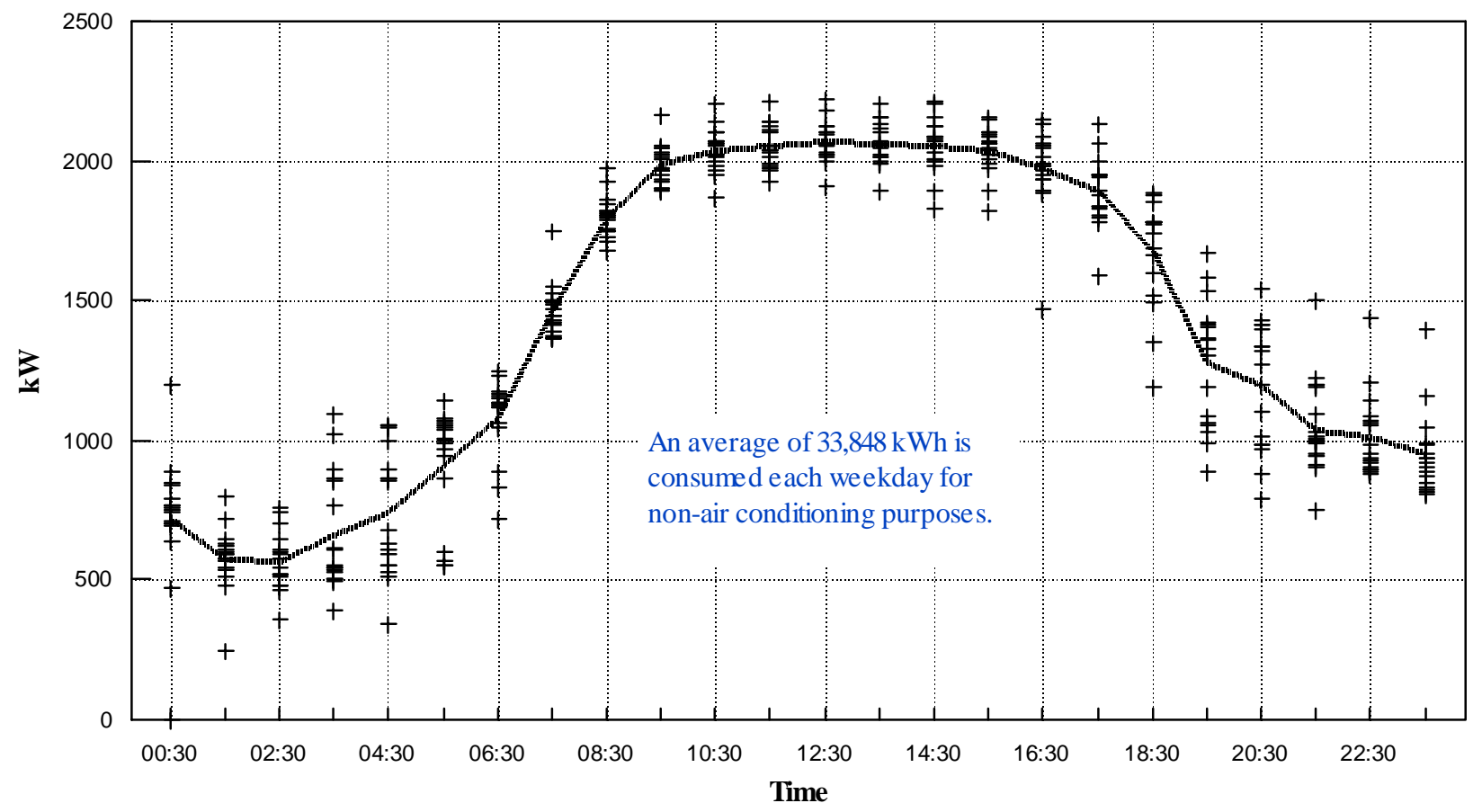

Figure 10. Non-Air Conditioning Power Demand of the CNG Tower 17 Weekdays throughout 1993

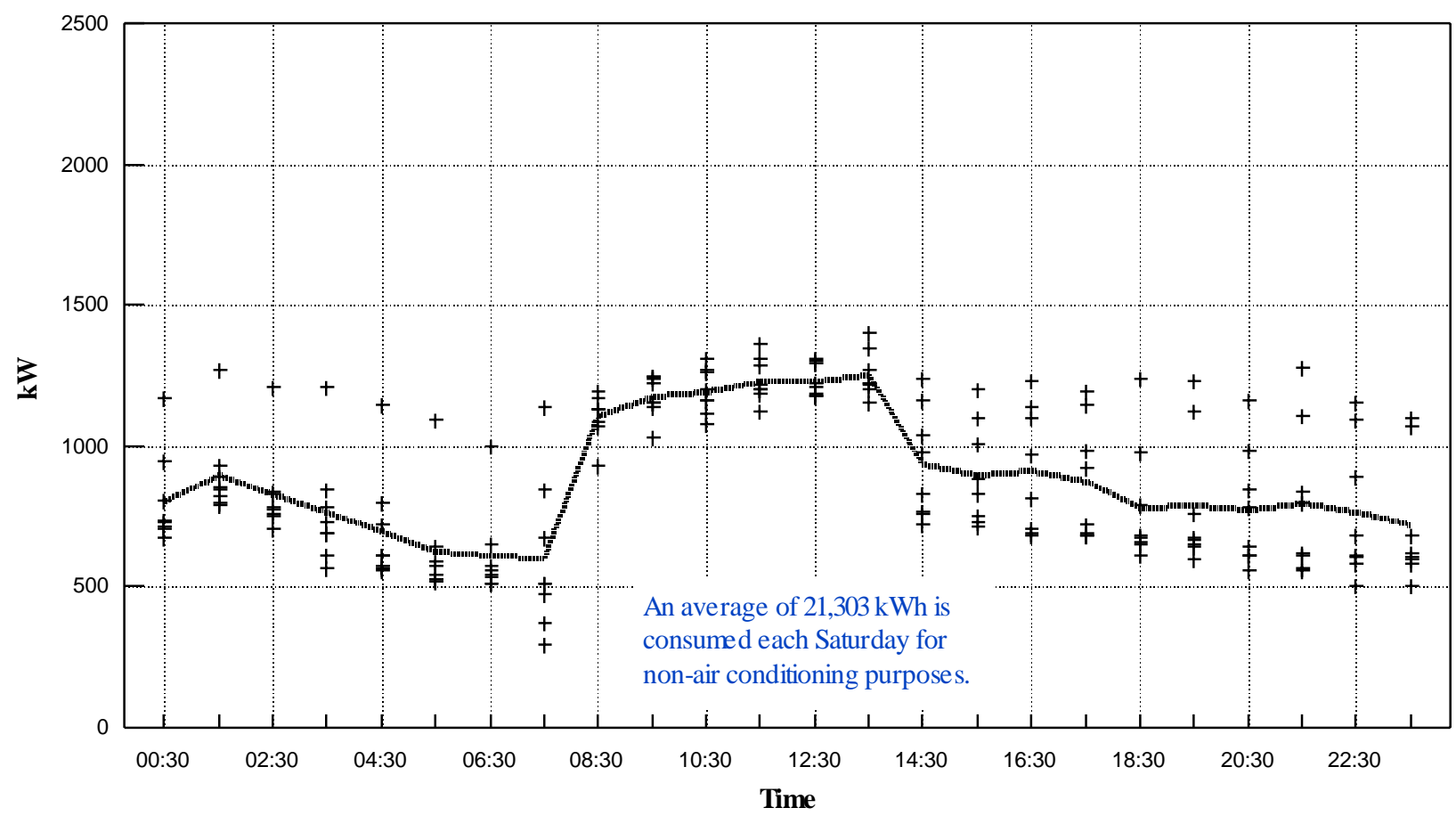

Figure 11. Non-Air Conditioning Power Demand of the CNG Tower

8 Saturdays throughout 1993 


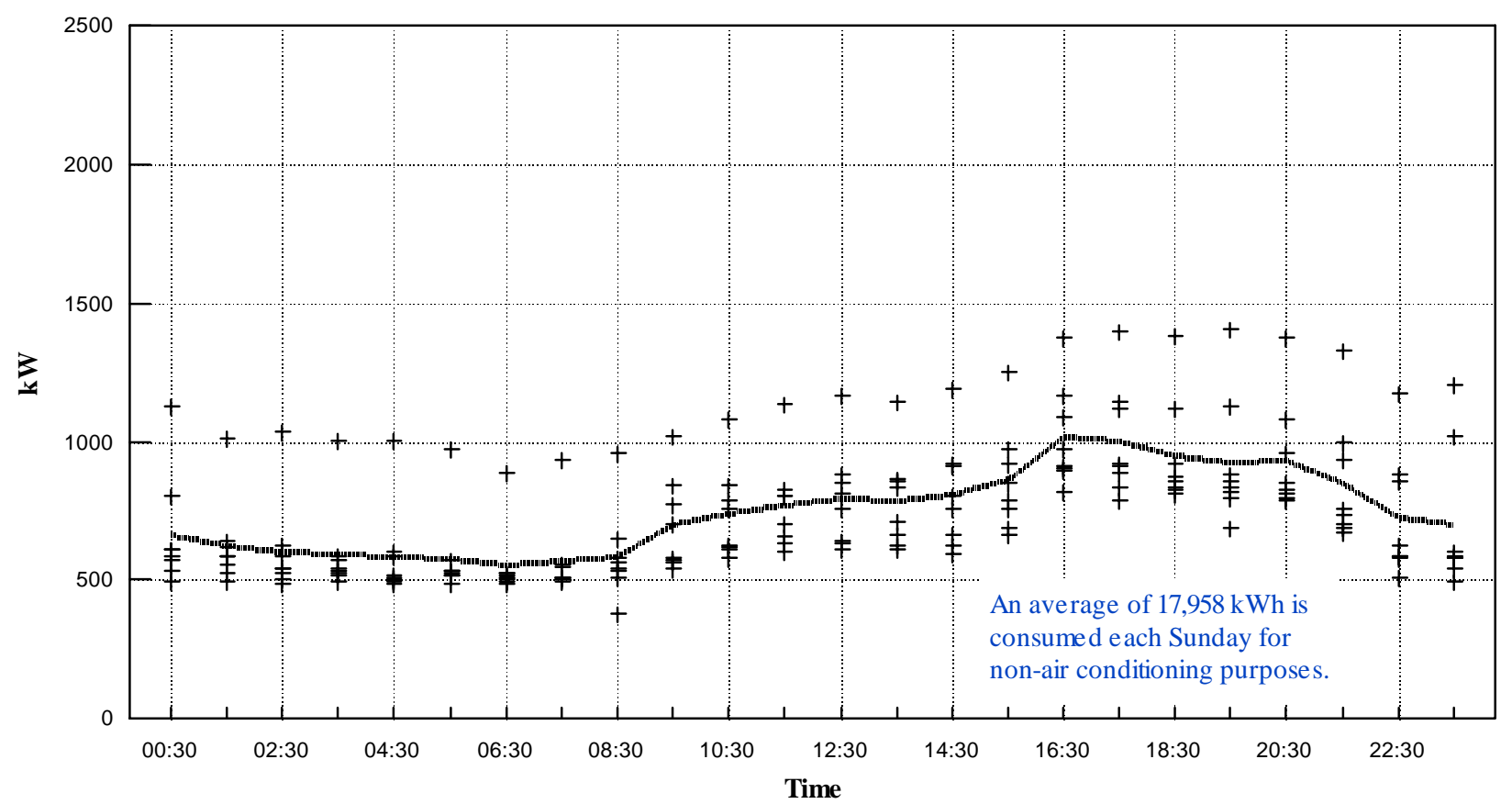

Figure 12. Non-Air Conditioning Power Demand of the CNG Tower 8 Sundays throughout 1993

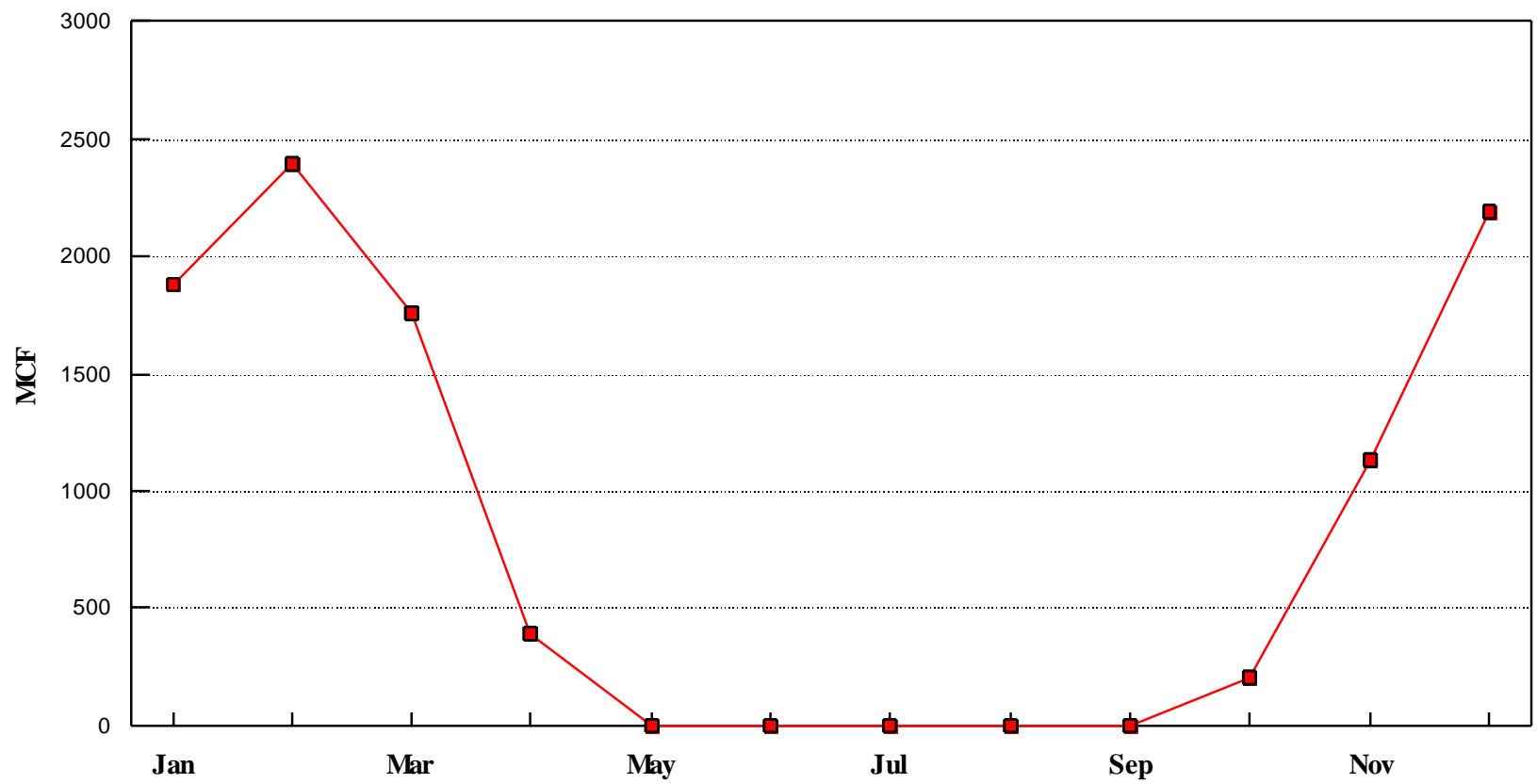

Figure 13. Monthly Natural Gas Use of the CNG Tower 1993 Space Heating 
Based on data from the days of January, February, and November 1993, Figure 14 shows the CNG Tower's daily gas usage (customarily measured just after midnight) correlated with the average outside temperature at the CNG Tower for the preceding day. The inclusion of the daily maximum and minimum air temperatures and the consideration of the day of the week did not significantly affect the accuracy of this correlation. Presumably, factors other than temperature may influence gas usage in the CNG Tower; for example, external factors such as wind velocity and solar radiation intensity and internal factors such as building occupancy and activity, but data are not available to explore the influence of these factors.

Surprisingly, gas usage on Saturdays and Sundays showed no significant deviation from the curve of Figure 14. The duct-mounted air heaters throughout the building continue to operate throughout the weekend around the clock as required by air temperature; thus hot water flow and gas usage in the boilers also continue. Apparently, the decreased need for heating when the ventilation system is no longer introducing cold outside air into the building is balanced by the decreased internal generation of heat due to lower building occupancy (body heat and power consumption).

The maximum of the daily average heating rates for 1993, conveyed by water supplied at 180-200 ${ }^{\circ} \mathrm{F}$ and returned at $150{ }^{\circ} \mathrm{F}$ or higher, was 400 tons, 4.8 million British thermal units per hour (MMBtu/hr), or $1410 \mathrm{~kW}$ based on the heat of combustion, higher heating value (HHV), of the natural gas fuel and the 80 percent HHV conversion efficiency of the existing boilers. An outside temperature extreme of $0{ }^{\circ} \mathrm{F}$ would require 500 tons, $6.0 \mathrm{MMBtu} / \mathrm{hr}$, or $1760 \mathrm{~kW}$ of space heating.

Air Conditioning. The chiller log provides the following at 5-minute intervals:

- The heat removal rate by chilled water circulating in the building;

- The power input to each of the two chillers (which typically operate alternately, since each is rated just slightly less than the maximum air conditioning demand);

- The chilled water supply and return temperatures; and

- The air temperature outside of the building.

The chiller log does not directly report the chilled water flow through the cooling loop.

The chiller logs indicate that the peak instantaneous operating level in 1993 was 900 tons, requiring $710 \mathrm{~kW}$. The observed total peak power demand of the building in 1993, $2790 \mathrm{~kW}$, was slightly less than the sum of the peak non-a.c. and air conditioning loads $(2220 \mathrm{~kW}+$ $710 \mathrm{~kW}=2930 \mathrm{~kW}$ ). This is not surprising since the building operators maximized the operating level of air conditioning in the morning, prior to the non-a.c. peak power demand, in order to reduce the overall peak demand and thus the electric utility bills.

Analysis of the 31 August 93 chiller data log, illustrated in Figures 15, 16, and 17, indicates the following: 


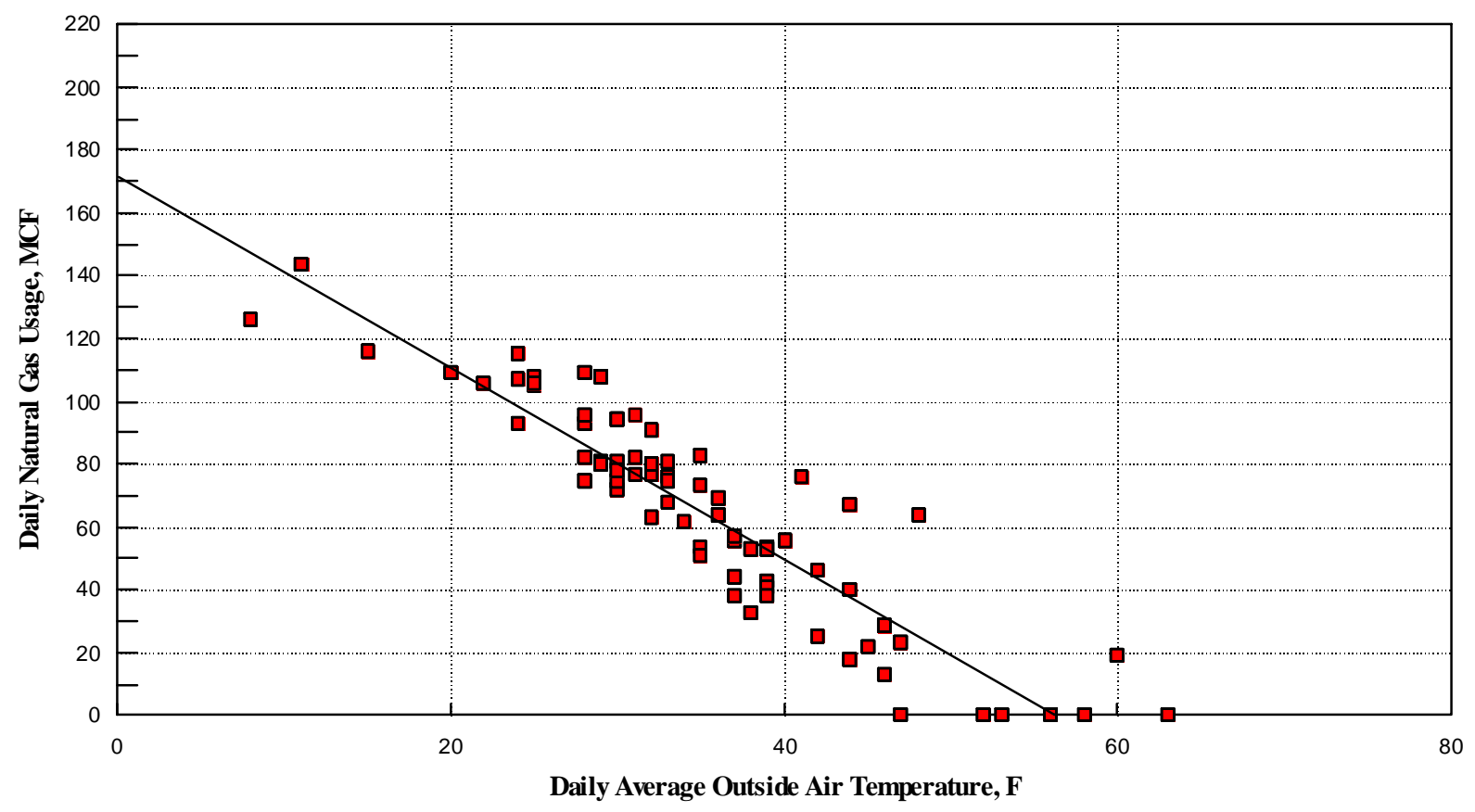

Figure 14. Effect of Outside Air Temperature on CNG Tower Natural Gas Usage Data from Jan., Feb., and Nov. 1993

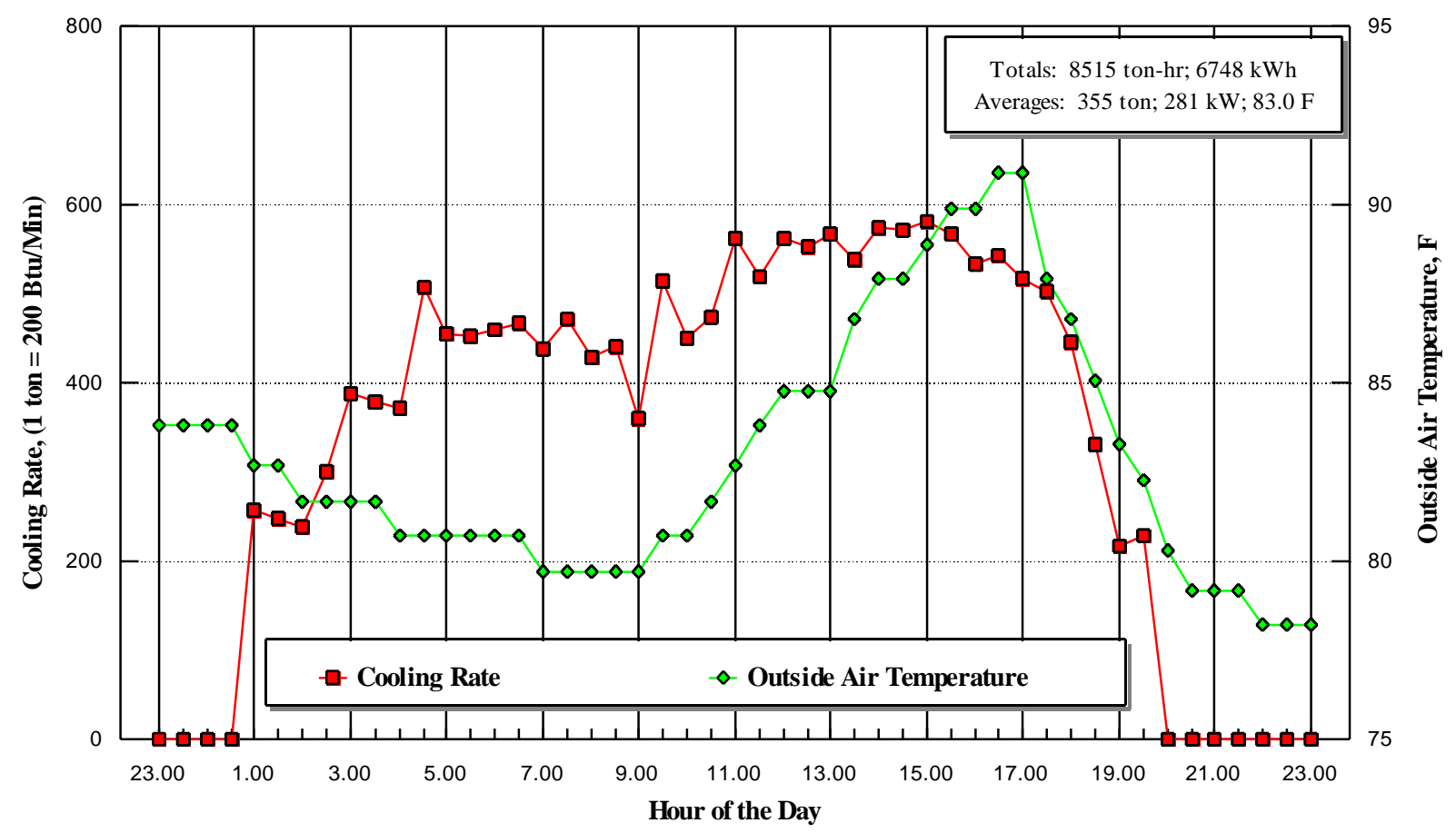

Figure 15. Hourly Air Conditioning Demand in the CNG Tower: 31 August 1993 


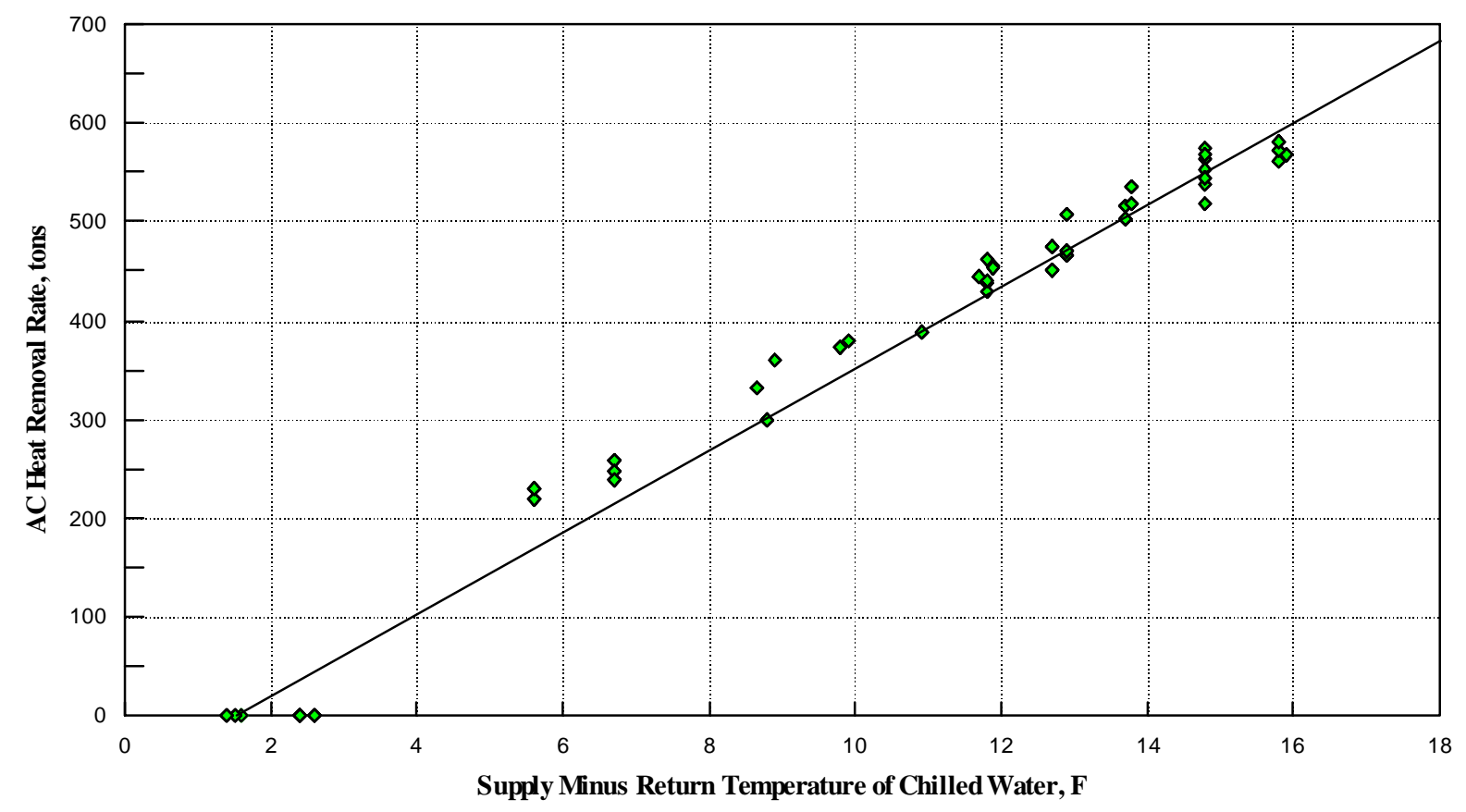

Figure 16. Air Conditioning Rate Proportional to Chilled Water Supply-Return Temperature Difference: 31 August 1993

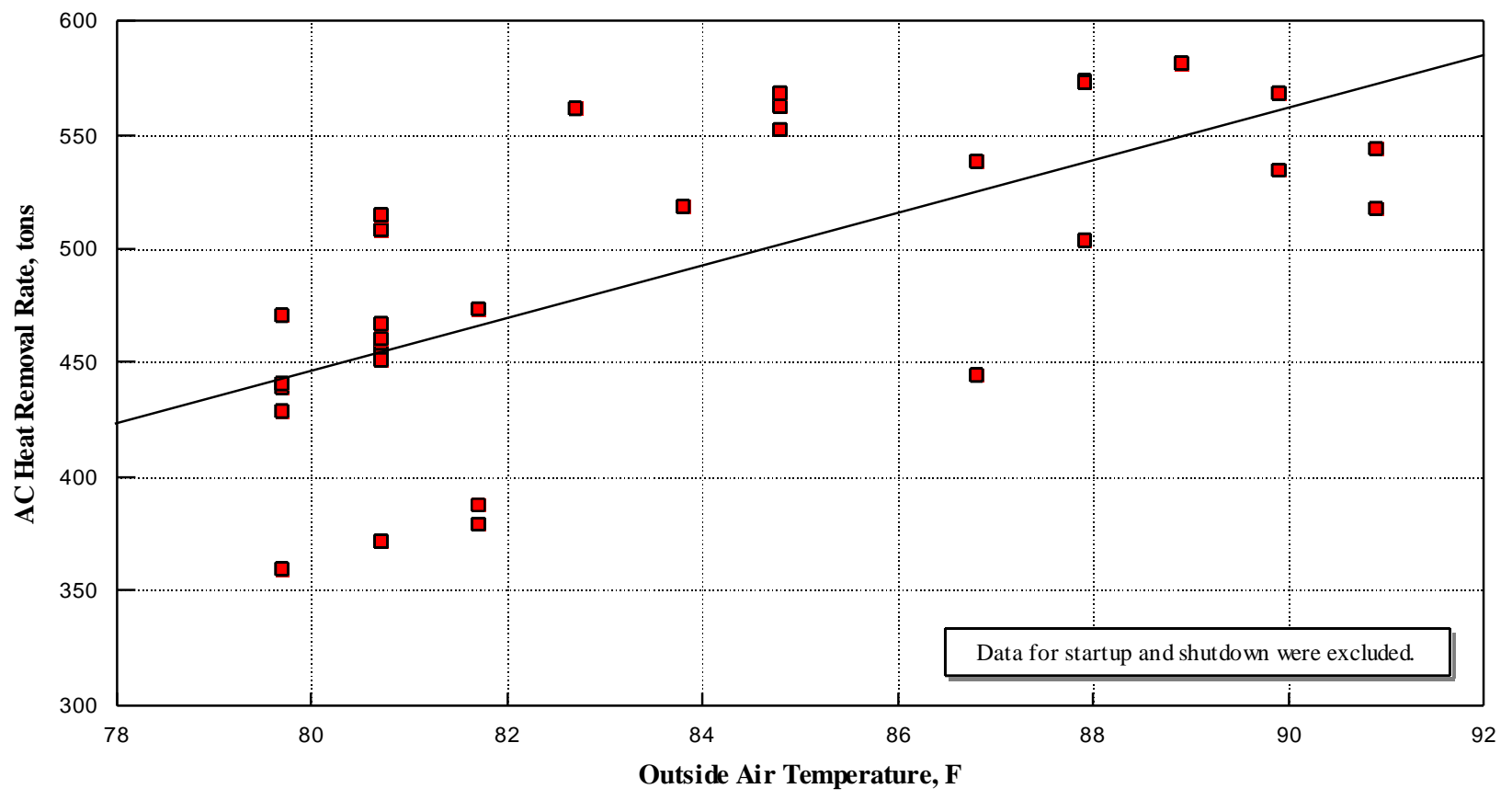

Figure 17. Hourly Effect of Outside Air Temperature on Air Conditioning Demand 31 August 1993 
- The outside air temperature varied between 78 and $91^{\circ} \mathrm{F}$, and one or other of the chillers operated at a varying level throughout the day.

- The chillers and building ventilation system were turned on early, before 6:00 a.m., in order to meet the overall anticipated cooling requirements for the building on this hot day. (The building heating system can operate independent of the ventilation system due to the duct heaters with their heating coils and fans. The building cooling system, however, has a central cooling coil on each floor and thus requires the operation of the ventilation system to cool the building. The records indicate the operation of the air conditioning, and thus the ventilation system, on some Sundays preceding expected hot weather.)

- The total heat removed from the building on this warm day in August $\left(83^{\circ} \mathrm{F}\right.$ average temperature) was 8515 ton-hour (ton-hr), or $102.18 \mathrm{MMBtu}$. The power consumed by the chillers was $6748 \mathrm{kWh}$, or $23.02 \mathrm{MMBtu}$. The ratio of power input to cooling rate achieved by the chillers is approximately constant, $0.79 \mathrm{~kW} /$ ton, after the first 15 minutes of operation. The corresponding coefficient of performance is thus 4.5. (An absorption chiller with a coefficient of performance of 0.7 would require $146 \mathrm{MMBtu}$ to achieve this cooling effect.)

- The overall building cooling rate, expressed in tons ( 1 ton $=12,000 \mathrm{Btu} / \mathrm{hr}$ ), was approximately proportional to the temperature difference between the chiller water supply and return temperatures, as shown in Figure 16. This proportionality implies a near constant chiller water flow to the HVAC system; calculations based on the heat removal rate and the supply and return temperature of the chilled water indicate that this flow was a constant, 874 GPM.

- The peak power consumption for air conditioning on that day was $466 \mathrm{~kW}$. (Throughout the year it was $710 \mathrm{~kW}$.) This peak air conditioning power demand was about 33 percent of the weekday average daily non-a.c. power demand and 21 percent of the weekday peak hourly non-a.c. power demand indicated in Table 1. If electrically driven vapor compression refrigeration were maintained in the CNG Tower for air conditioning, then the overall cogeneration arrangements would have to provide for this electrical load. If heat driven absorption refrigeration were adopted, then this air conditioning power demand could be reduced to the extent provided by the fuel cell's reject heat.

- The hourly cooling rate is approximately linearly related to the hourly outside air temperature as shown in Figure 17. The correlation coefficient, $\mathrm{R}^{2}$, is 0.46 . This correlation is poor for two reasons: (a) it does not include relative humidity, and (b) it assumes that the chillers responded instantaneously to changes in outside air temperature. In reality, when a hot day was anticipated, the chillers were frequently turned on early in the morning when the outside air temperature was still cool to get a "head start" on air conditioning. For these reasons, a daily correlation for air conditioning, which included relative humidity, was developed to replace this hourly correlation.

For each of the 33 days selected throughout 1993, the average air conditioning rate, MMBtu/hr, throughout the day was calculated. Grouped separately into three categories -weekdays, Saturdays, and Sundays -- these daily averages were then linearly correlated with both the average outside air temperature and the average relative humidity for the day as reported by 
the U.S. Weather Bureau. Three, distinct correlations were obtained. The weekday correlation is shown in Figure 18. The correlations for weekdays and Saturdays (correlation coefficients $\mathrm{R}^{2}=$ 0.89 and 0.84 , respectively) were much improved over the instantaneous correlation of Figure 17. For Sundays, the daily correlation remained poor, with an $\mathrm{R}^{2}$ of 0.43 , probably due to the sporadic use of air conditioning on Sundays. Overall, however, the instantaneous cooling rate correlation for 31 August 93 still approximates each of these daily correlations.

The maximum of the daily average air conditioning rates for 1993 (heat removed by water supplied at $45^{\circ} \mathrm{F}$ and returned at $55^{\circ} \mathrm{F}$ ) was slightly less than 600 tons, $7.2 * \mathrm{MMBtu} / \mathrm{hr}$, or $2100 \mathrm{~kW}$, of heat. According to the correlation in Figure 18, the CNG Tower would require an air conditioning rate of 730 tons, $8.8 * \mathrm{MMBtu} / \mathrm{hr}$, or $2600 \mathrm{~kW}$, when the ambient temperature reached an extreme of $100{ }^{\circ} \mathrm{F}$ and the relative humidity reached 100 percent. The existing, electrically driven, vapor compression chillers would require $580 \mathrm{~kW}$ (at $0.79 \mathrm{~kW} /$ ton) to provide this cooling rate.

If these same extreme conditions were experienced on a Saturday or Sunday, their correlations predict that much lower air conditioning rates would be required: 450 tons, $5.4^{*} \mathrm{MMBtu} / \mathrm{hr}$, or $1600 \mathrm{~kW}$; and 620 tons, $7.5^{*} \mathrm{MMBtu} / \mathrm{hr}$, or $2200 \mathrm{~kW}$, respectively.

Simultaneous Space Heating and Air Conditioning. The correlations for space heating, Figure 14, and weekday air conditioning, Figure 18, have been plotted in Figure 19. This figure illustrates the observation that simultaneous heating and cooling of the building are practiced over a certain range of outside air temperature and humidity. In this range air cooling is required to provide comfort in the core of the building while heating is required around its periphery, where heat is lost to the surroundings.

The heating and cooling curves of Figure 19 are approximately symmetrical, and they intersect at an outside temperature at which the heat losses from the building are equal to the heat released within the building. The slopes of the heating and cooling curves, approximately equal but opposite in sign, are closely related to the overall UA values (see definition below) for heat transfer between the CNG Tower and its surroundings. A detailed heat transfer analysis of Figure 19 is presented in Appendix A. The basic outline and conclusions of this analysis are:

$$
\begin{aligned}
& \mathrm{Q}_{\mathrm{h} / \mathrm{ac}}+\mathrm{Q}_{\mathrm{gen}}=\left(\mathrm{UA}+\mathrm{mC}_{\mathrm{p}}\right)\left(\mathrm{T}_{\mathrm{b}}-\mathrm{T}\right) \\
& \text { where: } \\
& \mathrm{Q}_{\mathrm{h} / \mathrm{ac}}=\quad \begin{array}{l}
\text { the rate of heat supplied }(+) \text { or removed }(-) \text { by the heating or air } \\
\text { conditioning system of the building, } \mathrm{kW} .
\end{array} \\
& \mathrm{UA}=\quad \begin{array}{l}
\text { the product of an overall heat transfer coefficient, } \mathrm{U} \text {, between the } \\
\text { building and its surroundings and the surface area, A, of the building, } \\
\mathrm{kW} /{ }^{\circ} \mathrm{F} .
\end{array} \\
& \mathrm{T}_{\mathrm{b}} \text { and } \mathrm{T}=\quad \text { the temperatures inside and outside the building, }{ }^{\circ} \mathrm{F} .
\end{aligned}
$$




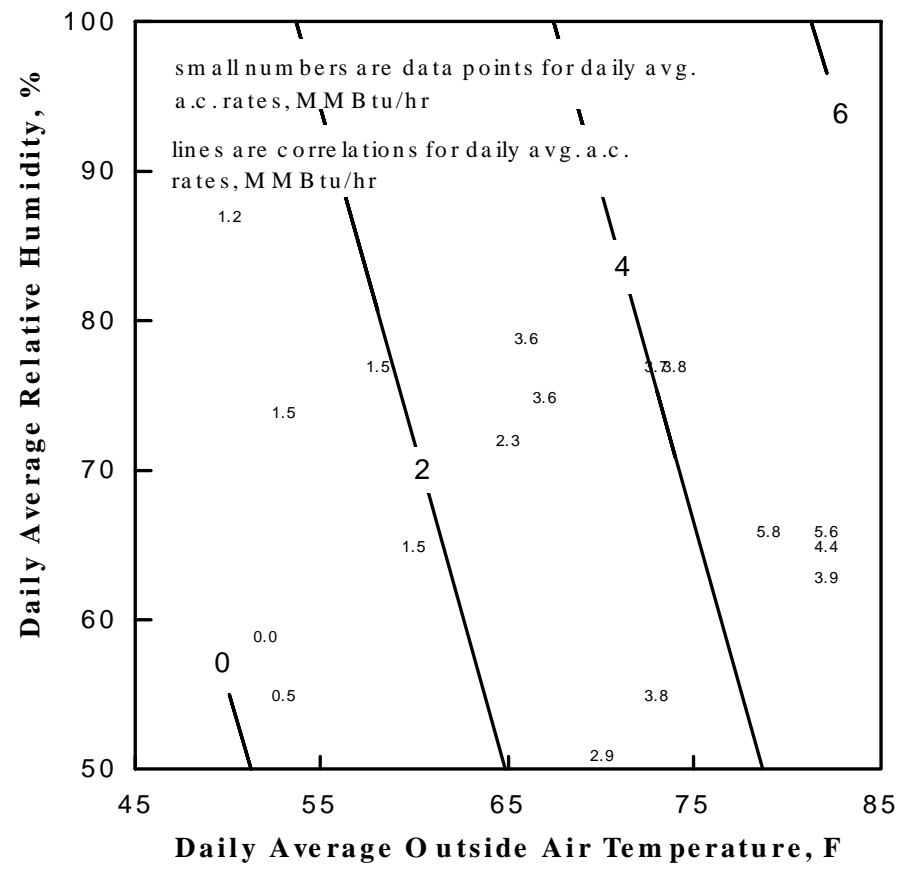

Figure 18. Effect of Outside Air Temperature and Relative Humidity on Weekday AC Demand

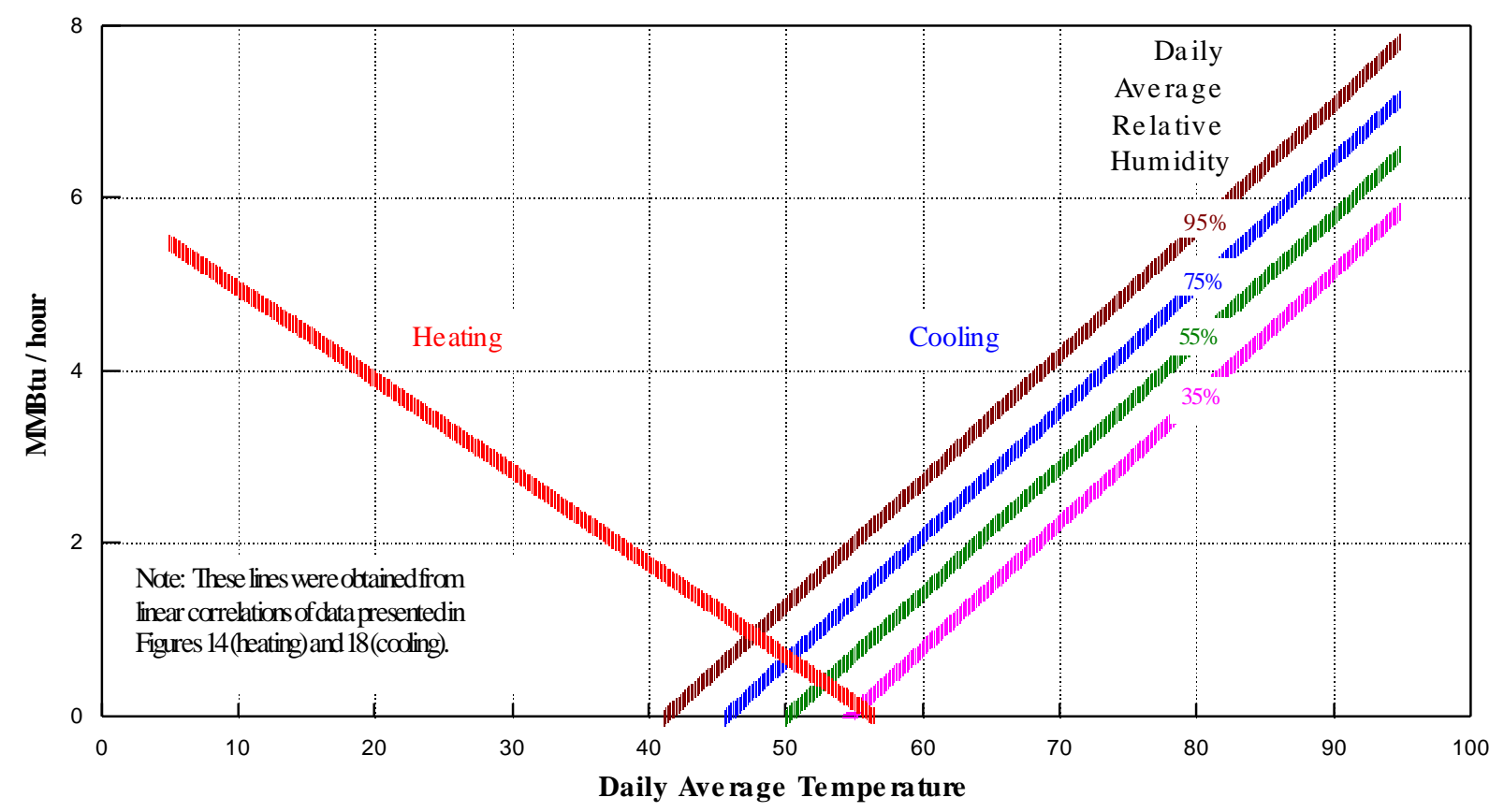

Figure 19. Effect of Outside Air Temperature and Relative Humidity on the CNG Tower's Weekday Heating and Air Conditioning Rates 


$$
\begin{aligned}
& \mathrm{Q}_{\mathrm{gen}}=\quad \begin{array}{l}
\text { the total rate of heat generation, sensible and latent, within the } \\
\text { building, primarily due to power consumption and building occupancy, } \\
\mathrm{kW} .
\end{array}
\end{aligned}
$$

The detailed analysis of Figure 19, presented in Appendix A, indicates that UA is $30.3 \mathrm{~kW} /{ }^{\circ} \mathrm{F}$, or $0.103^{*} \mathrm{MMBtu} / \mathrm{hr}^{\circ} \mathrm{F}$, on the heating side; and $43.9 \mathrm{~kW} /{ }^{\circ} \mathrm{F}$, or $0.150^{*} \mathrm{MMBtu} /$ $\mathrm{hr}^{\circ} \mathrm{F}$, on the air conditioning side. The value of $\mathrm{Q}_{\text {gen }}$, assuming $\mathrm{T}_{\mathrm{b}}$ is about $70{ }^{\circ} \mathrm{F}$, is within the broad range $345 \mathrm{~kW}$ to $1230 \mathrm{~kW}$ dependent on the humidity. Additional analyses would be required to deal with the UA values, the temperature of intersection, the rate of heat generation, and the separation of the humidity lines. Such analysis would contribute useful quantitative information about the building and its operation. The effect on the fuel cell cogeneration system design, however, would be minimal.

Water Consumption and Cooling Tower Operation. Most of the water used in the CNG Tower is for domestic purposes such as drinking, washing, and flushing. A portion is used, however, in a roof-mounted cooling tower to make up for water lost to evaporation and blow down. The cooling tower provides a coolant to the condensers of the chillers and also to the water-to-water heat exchanger, which, when the outside temperature and humidity are sufficiently low, can be used in place of the electric chillers to chill water for air cooling. The measured water evaporation in the cooling tower is an indication of the amount of heat rejected from the building. Calculations have shown that on 31 August 93 the heat of vaporization of the makeup water supplied to the cooling tower in excess of that removed by blow down corresponded to the heat energy removed by the electric chillers plus the electrical energy supplied to the chillers. (Additional heat is rejected from the building in the sensible and latent heat of the air exhausted from the building in the operation of the HVAC system.)

The cooling tower was operated even in the cold month of February 1993, when no chiller was operated. Presumably, some heat removal from the recirculated air was required in the water-to-water heat exchanger, even though 15 percent cold fresh air is added, in order to maintain a comfortable building temperature. Figure 20 shows the heat expelled through the cooling tower in February 1993.

1993 Utility Rate Structures. Energy cost information required to evaluate the economic benefits of cogeneration was obtained from the monthly electric, natural gas, and water bills of the CNG Tower.

The 1993 electricity bills indicate the following rates:

- A $\$ 0.0397 / \mathrm{kWh}$ energy charge,

- A $\$ 6223$ charge for the first $300 \mathrm{~kW}$ (or less) demand, and

- A $\$ 15.65 / \mathrm{kW}$ charge for demand above $300 \mathrm{~kW}$.

The CNG Tower consumed a total of 11,306 megawatt-hours (MWh) in 1993 and was charged a total of $\$ 929,000$. The electricity charges averaged $\$ 77,000 /$ month, and were nearly evenly 


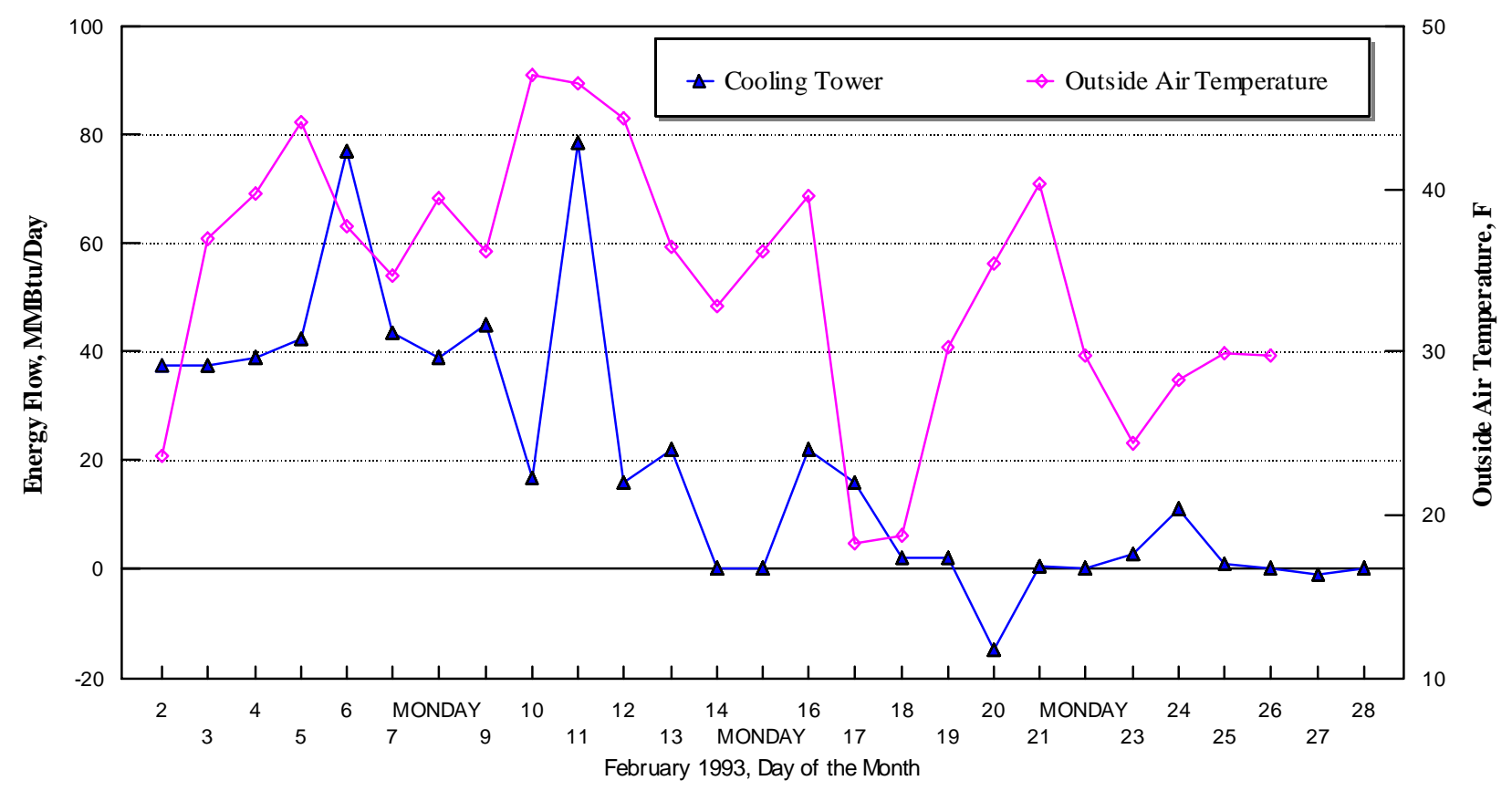

Figure 20. Air Conditioning Via the Water-to-Water Heat Exchanger and Cooling Tower

divided between demand and energy charges. The average effective electric rate in 1993 was $\$ 0.082 / \mathrm{kWh}$.

The 1993 gas bills indicate the following rates:

- $\$ 2.00 / \mathrm{MCF}(\mathrm{MCF}=$ thousand cubic feet) for transport of gas purchased elsewhere,

- $\$ 5.68 / \mathrm{MCF}$ for supply of firm contract gas,

- $\$ 0.47 / \mathrm{MCF}$ based on winter peak demand of $1714 \mathrm{MCF}$, and

- $\quad \$ 0.05 / \mathrm{MCF} * 1714 \mathrm{MCF}$ monthly penalty for peak use.

In 1993, the CNG Tower used a total of 10,281 MCF for space heating.

The 1993 water bills indicate the following rates:

- $\$ 3.00 /$ thousand gallons.

The quarterly water bills for the CNG Building averaged approximately \$7,000 in 1993 . 


\section{Design of a Fuel Cell Cogeneration System to Retrofit the CNG Tower}

\subsection{Design Methodology}

The analysis of the design and operation of the CNG Tower's HVAC system, presented above in Section 2, is the first step in the design of a retrofit cogeneration system for the existing building. This analysis provides the information necessary for the second step in the design: the selection, sizing, and integration of the components of the cogeneration system; and the estimation of its technical performance. The third step is a preliminary evaluation of the economic performance of the cogeneration system based on its operating and capital costs and the comparison with the alternative of continued purchase of power and fuel for the existing HVAC system. If this economic evaluation appears attractive, a layout, detailed design, cost estimate, and finally installation and operation of the cogeneration system are the subsequent steps of the process. Appendix $\mathrm{C}$ presents a more detailed presentation of the design methodology.

\subsection{System Configuration and Component Characterization}

A generalized diagram of the fuel cell cogeneration systems which were designed for the CNG Tower is shown in Figure 21. Its components include:

- The fuel cell stacks for power generation. The phosphoric acid fuel cell (PAFC) was chosen for this study for two reasons: (1) it is commercially available with documented technical performance, and (2) it rejects heat to water at a temperature sufficiently high for both space heating and absorption chilling. The performance of the PAFC in this study is based on the ONSI PC25C fuel cell system, which generates $200 \mathrm{~kW}$. In the near future, more efficient, higher temperature fuel cells will be commercialized, such as the molten carbonate and solid oxide types. Their higher temperatures will broaden the options for cogeneration.

- Exchangers for heat recovery and delivery of the heated fluids -- air, water, or steam, for example -- to equipment involved with use of the heat. In the ONSI system these exchangers are included in the overall fuel cell system; they deliver hot water streams at two different temperatures.

- Equipment for waste heat usage -- for example, the existing hot water coils in the duct heaters of the building and a lithium bromide based absorption water chiller, operating on hot water, to be installed to provide cold water to the existing air conditioning, cooling coils on each floor of the building.

- Auxiliary equipment for heating and cooling the building if and when inadequate waste heat is available from the fuel cell system for these purposes. One of the existing gas-fired boilers and one of the electrically operated vapor compression chillers could serve this purpose. 


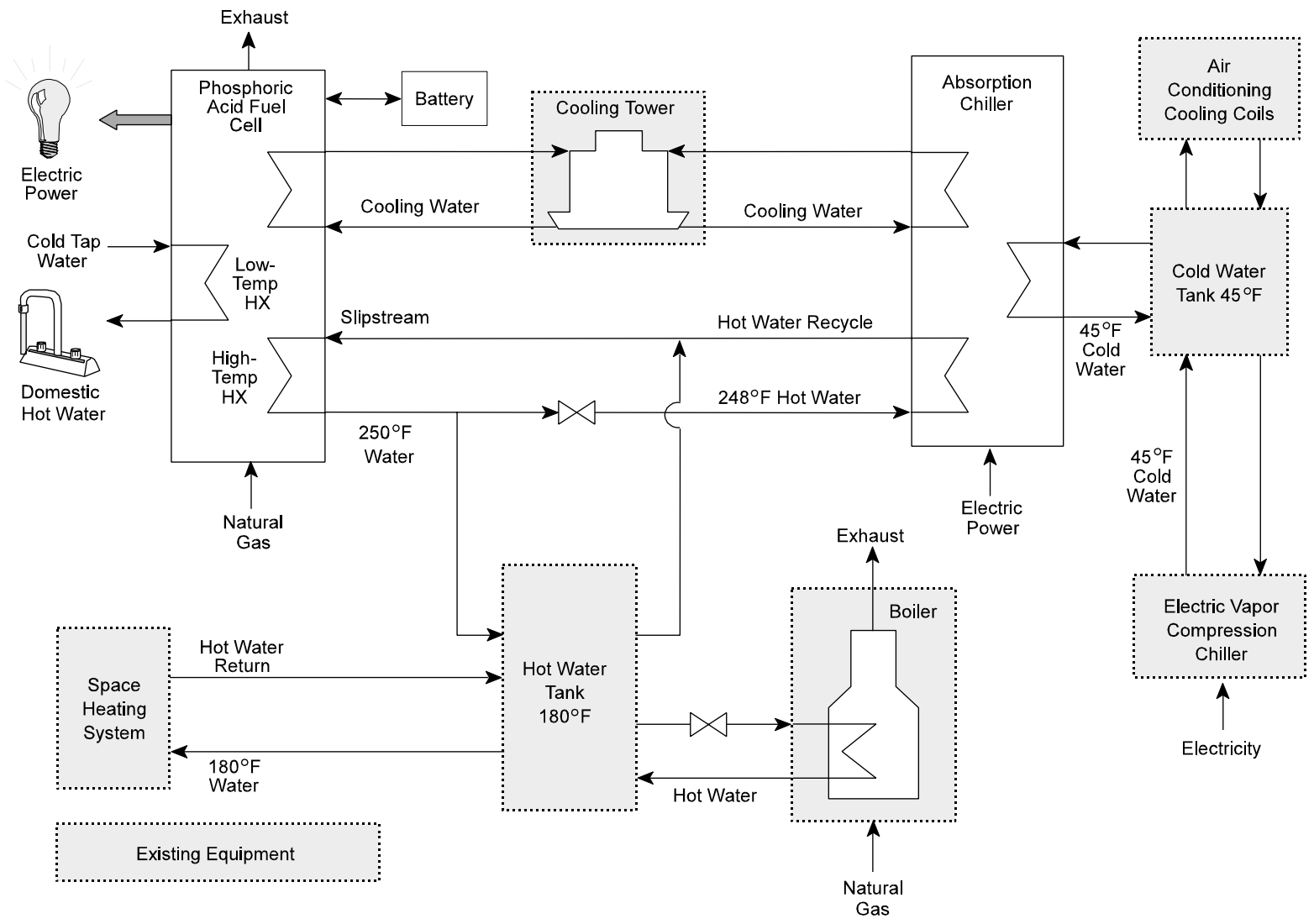

Figure 21. Cogeneration System Configuration for Fuel Cell Retrofit of the CNG Tower Supplies Electricity to the Building and Hot and Chilled Water to the HVAC System

- Equipment for providing emergency power in case of fuel cell inadequacy or outage. Alternatively, the local utility might provide backup power as a service.

- Equipment for the rejection of waste heat from the fuel cell to the surroundings if heat use in the building heating and or cooling is less than its production.

- Battery storage for electrical energy; storage can be useful in leveling loads and in providing for emergency operation.

- Pumps, valves, and instruments for operation and control of the system in combination with the HVAC system of the building.

Performance data for the major components of the fuel cell cogeneration system for the CNG Tower are presented in Table 2. The data includes the measured performance of the Tower's existing natural gas boilers; electric, vapor compression chillers; and cooling tower. Performance data for the PAFC and the absorption chiller are based on commercially available equipment specifications from ONSI Corporation and York International. 
Table 2. CNG Tower Fuel Cell Cogeneration System Equipment Performance Data

\begin{tabular}{|c|c|c|}
\hline $\begin{array}{l}\text { Natural Gas- } \\
\text { Fired Boiler }\end{array}$ & Thermal Efficiency: & $\begin{array}{l}88 \text { Percent on a Lower Heating Value }\left(\mathrm{LHV}^{1}\right) \\
\text { Basis }\end{array}$ \\
\hline Electric Chiller & Required Power: & $0.79 \mathrm{~kW}_{\mathrm{e}}$ Per Ton Air Conditioning \\
\hline Battery Storage & $\begin{array}{l}\text { DC-DC Round- } \\
\text { Trip Efficiency: }\end{array}$ & 0.78 \\
\hline Cooling Tower & Capacity: & $\begin{array}{l}30 \mathrm{MMBtu} / \mathrm{hr} \text {, Based on } 6000 \mathrm{GPM} \text { at } 95{ }^{\circ} \mathrm{F} \\
\text { Water Inlet, } 85{ }^{\circ} \mathrm{F} \text { Water Outlet, and } 75{ }^{\circ} \mathrm{F} \text { Wet } \\
\text { Bulb }\end{array}$ \\
\hline \multirow[t]{2}{*}{$\begin{array}{l}\text { Lithium Bromide } \\
\text { Absorption } \\
\text { Chiller }\end{array}$} & Required Heat: & $\begin{array}{l}\text { 1.4 Tons Heat Input Per Ton Air Conditioning } \\
(\mathrm{COP}=0.7)^{2} \\
240-250{ }^{\circ} \mathrm{F} \text { Hot Water Inlet } \\
\approx 224^{\circ} \mathrm{F} \text { Hot Water Outlet }\end{array}$ \\
\hline & Required Power: & $0.15 \mathrm{~kW}_{\mathrm{e}}$ Per Ton Air Conditioning \\
\hline \multirow[t]{2}{*}{$\begin{array}{l}\text { Phosphoric Acid } \\
\text { Fuel Cell (PAFC) }\end{array}$} & $\begin{array}{l}\text { Electrical Efficiency: } \\
\text { Rejected Heat } \\
250^{\circ} \mathrm{F} \text { Hot Water } \\
\text { Outlet: }\end{array}$ & $\begin{array}{l}3500 \mathrm{Btu} / \mathrm{hr} \text { per } \mathrm{Kw}_{\mathrm{e}} \text { Produced Above } 50 \text { Percent } \\
\text { PAFC Rated Capacity (Given Hot Water Inlet } \leq \\
230{ }^{\circ} \mathrm{F} \text { ) }\end{array}$ \\
\hline & $\begin{array}{l}140{ }^{\circ} \mathrm{F} \text { Hot Water } \\
\text { Outlet: }\end{array}$ & $\begin{array}{l}2333 \mathrm{Btu} / \mathrm{hr} \text { per } \mathrm{kW}_{\mathrm{e}} \text { Produced Above } 25 \text { Percent } \\
\text { PAFC Rated Capacity (Given Hot Water Inlet } \leq \\
80^{\circ} \mathrm{F} \text { ) }\end{array}$ \\
\hline
\end{tabular}

${ }^{1}$ The lower heating value of natural gas was assumed to be 950,000 Btu/MCF.

${ }^{2}$ The absorption chiller's COP (coefficient of performance) is highly dependent on the temperature of the heat it is provided with. Higher temperature heat (e.g., $>550{ }^{\circ} \mathrm{F}$ ) can yield a COP greater than 1.1, while significantly increasing the chiller's cooling capacity. 


\subsection{System Capacity Requirements}

The purpose of the analysis of gas, power, water, and chiller data for the CNG Tower is to provide the information necessary for the selection and configuration of new and existing components for a cogeneration system which most effectively and economically provides for the energy requirements of the CNG Tower.

Electric Power, Energy Storage. The electric power and energy storage requirements for the fuel cell cogeneration system for the CNG Tower can be selected based in part on the 15-minute rolling average power demand data for February 1993 shown in Figures 8 and 9; the demand data throughout the year shown in Figures 10, 11, and 12; and the information presented in Table 1.

The capacity of a fuel cell cogeneration system designated for the building must take into consideration the following observations:

- The peak power demand of the CNG Tower in 1993 excluding power for air conditioning was $2200 \mathrm{~kW}$. The total, overall peak power demand, including air conditioning, was $2790 \mathrm{~kW}$.

- The peak operating level of the vapor compression chiller system for air conditioning the CNG Tower in 1993 was 900 tons, requiring $710 \mathrm{~kW}$. The observed total peak power demand of the building in 1993, $2790 \mathrm{~kW}$, was slightly less than the sum of the peak non-air conditioning and air conditioning loads. (Building operators maximized the operating level of air conditioning in the morning, prior to the non-air conditioning peak power demand, in order to reduce the overall peak demand and thus the electric utility bills.) A cooling rate of 730 tons is required, as indicated in Figure 18, to air condition the CNG Tower at the extreme building ambient conditions of $100^{\circ} \mathrm{F}$ and 100 percent humidity. Electrically driven, vapor compression chillers require $580 \mathrm{~kW}, 0.79 \mathrm{~kW} /$ ton, to provide this cooling rate. Heat driven, absorption refrigeration chillers might be installed to provide some or all of the cooling requirements of the building. Such chillers would require a heat supply of approximately 1.4 ton for each ton of cooling required. Reject heat from the fuel cell cogeneration system could provide up to 300 tons of cooling depending on the generating capacity of the system and the temperature at which the heat is available. Supplemental firing with natural gas fuel would be required if the full air conditioning load of the building were to be met by absorption chillers. These chillers would also require an electrical input of $0.15 \mathrm{~kW} /$ ton to operate their pumps and auxiliary equipment.

- The weekday average non-a.c. power demand of the CNG Tower in 1993 was $1410 \mathrm{~kW}$, as indicated in Table 1. If a fuel cell were operated constantly at this average load, then $6185 \mathrm{kWh}$ of ideal electrical energy storage (i.e., no losses in storing and in recovering the energy) would be required to levelize the building's demand.

- The base load, or daily minimum electric power demand, of the CNG Tower in 1993 was approximately $600 \mathrm{~kW}$. 
The electrical capacity of the fuel cell power generation component might be established either by the peak, average, or base load demands of the building. The system might be designed and operated to follow the power demand to the extent possible. Or perhaps alternatively, the system might be designed and operated to provide a constant power output with a battery storage system or the local electrical utility compensating for the difference in power generated and consumed by the building. The choice of the fuel cell power generation system capacity and operating mode depends upon:

- The choice of the technology for the air conditioning -- electrically driven vapor compression making use of the existing water chillers, heat-driven absorption refrigeration requiring the installation of replacement chillers, or a combination of both.

- The provision of electrical energy storage, batteries, enabling the fuel cell power system to operate, for example, at the daily average power demand, providing for valleys and peaks in demand by adding to or removing power from storage. (The battery system might also serve to provide emergency power in case of system outage.)

- The policy of the local electric utility regarding rates for providing power to or purchasing power from cogeneration facilities -- on a regular, dispatched, or emergency basis. If the local utility, Duquesne Light, were short on power in the area surrounding the CNG Building, perhaps because of transmission or distribution line limitations, the rates paid for excess power from a cogeneration facility may favor a generation capacity equal to or even higher than the peak demand.

- The balance between power and heat needs of the building. (Is the waste heat produced in meeting the power demand equal to, greater than, or less than that required for space heating, water heating, and air conditioning by means of absorption refrigeration chillers?)

Overall cogeneration system technical and economic performance calculations are required to evaluate the merits of the various choices of system capacity and operating modes.

Heating. The heating requirements based on the daily natural gas usage for the CNG Building are shown in Figures 14 and 19 as a function of the ambient temperature. These requirements did not vary with the day of the week. The maximum daily average heating rate for 1993, conveyed by water supplied at $180-200{ }^{\circ} \mathrm{F}$ and returned at $120{ }^{\circ} \mathrm{F}$, was 500 tons, $6.0^{*} \mathrm{MMBtu} / \mathrm{hr}$, or $1765 \mathrm{~kW}$ of heat based on the heat of combustion, higher heating value, of the natural gas fuel. An ambient temperature extreme of $0{ }^{\circ} \mathrm{F}$ requires 625 tons, $7.5^{*} \mathrm{MMBtu} / \mathrm{hr}$, or $2200 \mathrm{~kW}$ of heat.

Air Conditioning. The air conditioning requirements of the CNG Tower based on chiller operation reported at 20-minute intervals are shown in Figures 17 and 18 as a function of the daily average ambient temperature and humidity. These requirements did not vary with the day of the week. The maximum daily average heat removal rate for 1993, removed by water supplied at $45^{\circ} \mathrm{F}$ and returned at $55^{\circ} \mathrm{F}$, was slightly less than 600 tons, $7.2 * \mathrm{MMBtu} / \mathrm{hr}$, or $2110 \mathrm{~kW}$ of heat. An ambient temperature extreme of $100{ }^{\circ} \mathrm{F}$ with a relative humidity of 100 percent would require 730 tons, $8.8 * \mathrm{MMBtu} / \mathrm{hr}$, or $2600 \mathrm{~kW}$ of heat. 
As pointed out above, these air conditioning requirements might be met by the present, electrically powered vapor compression chillers, by newly installed heat-powered absorption refrigeration chillers, or by a combination or both. The coefficient of performance of commercially available, hot water-driven absorption refrigeration chillers is about $0.7 \mathrm{Btu}$ of heat removed/Btu supplied.

Overall Requirements. Table 3 summarizes the recommended capacities for the various fuel cell cogeneration system components required by the CNG Tower.

Table 3. CNG Tower Fuel Cell Cogeneration System Capacity Requirements

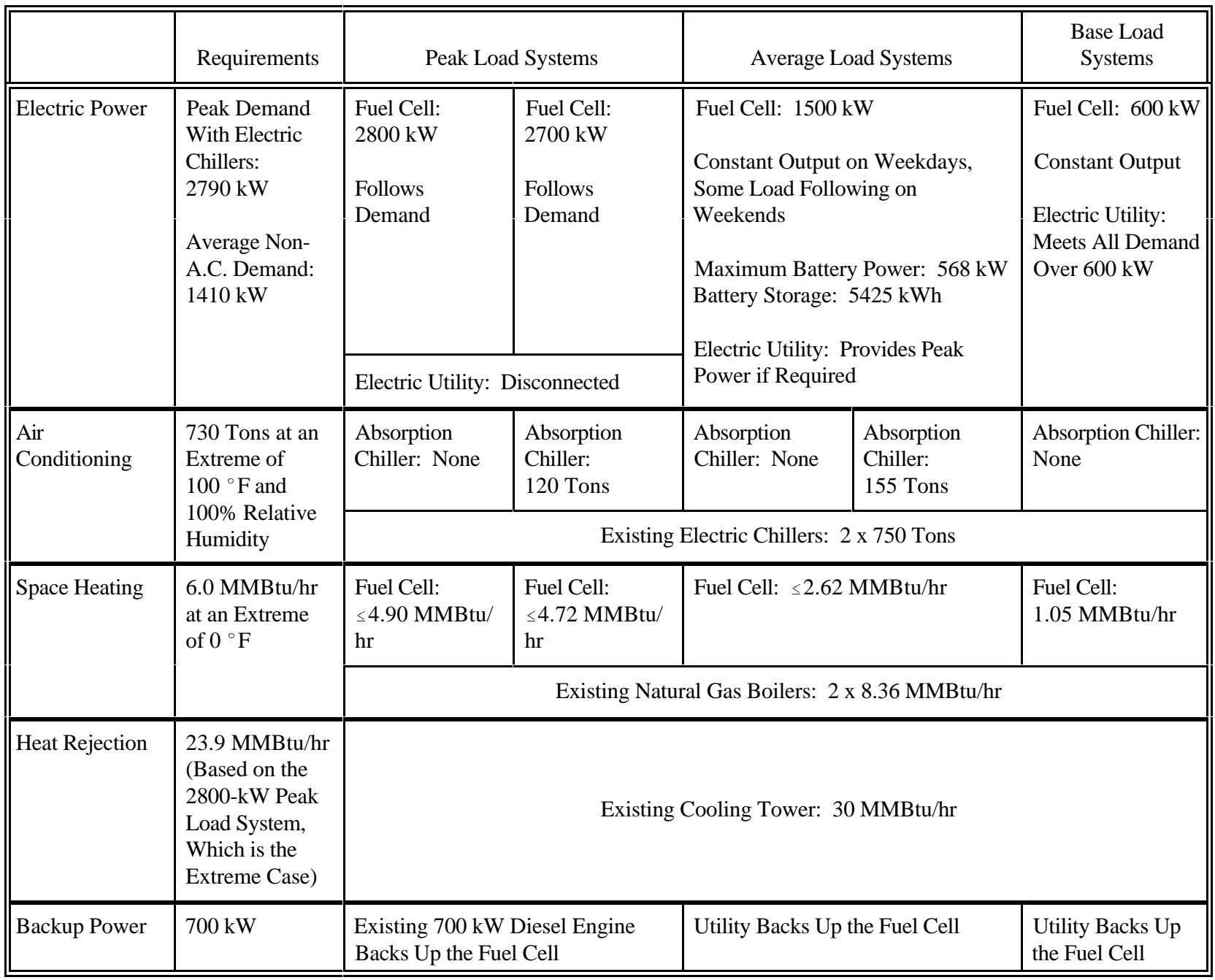

\subsection{System Generation and Operation Alternatives}

The three columns on the right of Table 3 define the five fuel cell cogeneration systems for the CNG Tower whose technical and economic performance have been evaluated: peak and 
average electrical load systems with and without absorption chillers; and a base electrical load system without an absorption chiller.

- Peak Load System: This system would continuously follow the building's entire load, including the air conditioning load. Depending on which option is chosen for backup power, this system could allow the building to disconnect from the local utility. (This peak load system could also be dispatched to produce excess, off peak, power, to sell to the local utility, but this case was not evaluated in this study.)

- Average Load System: In this system, the fuel cell would operate continuously in tandem with a battery storage system. The system is sized such that it delivers all the electricity required by the CNG Tower on a weekday when air conditioning is not needed, $33,848 \mathrm{kWh}$. (Due to battery losses the fuel cell must actually generate slightly more power than it delivers to the building -- 35,376 kWh.) In this way, utility power will only be required in the summer, when air conditioning increases the daily electricity consumption. On those weekdays which require air conditioning, the utility would provide the electricity required in excess of $33,848 \mathrm{kWh}$. The battery storage system would enable the system operator to accept the required utility power over a period of time which minimizes the peak daily demand from the electric utility.

Much less non-a.c. power is required by the CNG Tower on weekends. Therefore, on most weekend days, the average load system would be able to deliver all the power required, including power needed for air conditioning. On weekends, the fuel cell would follow the building load whenever the batteries were fully charged.

- Base Load System: In this system, the fuel cell capacity is selected sufficiently low so that it can operate continually at its rating. The local electric utility would provide all the power required above this base load.

The peak and average load capacity systems were considered with and without an absorption chiller for supplemental air conditioning. The heat rejected from the base load capacity system is insufficient to drive a practical, commercially available absorption chiller; this system was considered with only the electrical, vapor compression chiller. In all, therefore, these five preliminary designs were considered which would meet the CNG Tower's energy needs for the year 1993.

\subsection{Sizing of the Fuel Cell}

The fuel cell for the peak load system without an absorption chiller was sized at $2800 \mathrm{~kW}$. This is slightly above the CNG Tower's overall 1993 peak power demand of $2790 \mathrm{~kW}$, which included the power demand for the electric chillers. Since the peak load system is designed to operate independent of the local utility, any load-growth in the CNG Tower's near future should be considered when sizing the peak load system. For this study, we have assumed that the CNG Tower will not exceed its 1993 power demands in the foreseeable future.

The fuel cell for the peak load system with an absorption chiller was sized at $2700 \mathrm{~kW}$. Since an absorption chiller relies primarily on heat rejected from the fuel cell to supply air conditioning, 
a reduction in the CNG Tower's peak demand is realized when the absorption chiller is used. The 120-ton absorption chiller selected for the peak load system uses much less power, $0.15 \mathrm{~kW} / \mathrm{ton}$, for air conditioning than does the CNG Tower's electric chiller, $0.79 \mathrm{~kW} / \mathrm{ton}$. Consequently, when the absorption chiller is operating at full capacity, it reduces the power required for air conditioning by $77 \mathrm{~kW}[(0.79-0.15) * 120=77]$. A corresponding reduction is expected in the CNG Tower's peak demand of $2790 \mathrm{~kW}$, yielding a revised peak of $2713 \mathrm{~kW}$. Therefore, a 2700-kW fuel cell was selected.

The fuel cell power unit for the average load system, with and without an absorption chiller, was sized at $1500 \mathrm{~kW}$ as illustrated in Figure 22. The weekday average non-a.c. power demand of the CNG Tower in 1993 was $1410 \mathrm{~kW}$ as indicated in Table 1. If a fuel cell were operated constantly at this average load, then $6185 \mathrm{kWh}$ of ideal electrical energy storage (i.e., no losses in storing and in recovering the energy) would be required to levelize the building's demand. If this storage were provided by batteries with a storage efficiency [(battery discharge energy)/(battery charge energy)] of 0.78 (EPRI Report, 3), then the battery and the fuel cell capacities would both have to be increased to $594 \mathrm{~kW}$ and $1474 \mathrm{~kW}$, respectively. And consequently, a reduced battery storage capacity, about $5425 \mathrm{kWh}$, would then be required to meet the needs of the building. The $1474 \mathrm{~kW}$ fuel cell capacity has been rounded to $1500 \mathrm{~kW}$, which reduces the required battery power to $568 \mathrm{~kW}$. Figure 23 illustrates the typical state of charge of the batteries throughout the course of a weekday.

The fuel cell for the base load system was sized at $600 \mathrm{~kW}$. As shown by Figures 10-12 and Table 1, the minima of the average hourly demand profiles for Sundays, Saturdays, and weekdays are 557, 603, and $565 \mathrm{~kW}$, respectively. Therefore, a $600-\mathrm{kW}$ fuel cell, a size likely to be offered in a commercial package, is small enough to insure that the fuel cell's full capacity will be required by the CNG Tower nearly continuously on every day of the week, year round.

\subsection{Sizing of Balance of Plant Components}

An ONSI PC25C fuel cell system operating at its full 200-kW capacity delivers heat in the form of hot water -- $350,000 \mathrm{Btu} / \mathrm{hr}, 102.6 \mathrm{~kW}$ at $250{ }^{\circ} \mathrm{F}$ and $350,000 \mathrm{Btu} / \mathrm{hr}, 102.6 \mathrm{~kW}$, at $140^{\circ} \mathrm{F}$. Figure 24 for an earlier model of the ONSI system shows that the heat available from the system is dependent on the supply and return temperatures of the water heat transfer media. Furthermore, the heat output per kilowatt of power generation decreases with load. For example, at 50 percent power load no reject heat is available from the ONSI system at the $250{ }^{\circ} \mathrm{F}$ level; and at 20 percent power load none at the $140{ }^{\circ} \mathrm{F}$ level. Appendix B provides a preliminary analysis of heat availability from a low-temperature phosphoric acid fuel cell system. This analysis indicates that heat availability in a heat transfer media is critically dependent on the fuel cell operating conditions, system configuration, and auxiliary equipment specifications.

The PAFC's $250{ }^{\circ} \mathrm{F}$ reject heat can be utilized for space heating, which requires $180{ }^{\circ} \mathrm{F}$ hot water, or by the absorption chiller, which requires $240-250{ }^{\circ} \mathrm{F}$ hot water. The PAFC's $140{ }^{\circ} \mathrm{F}$ reject heat is too cool for these applications but can be used to heat domestic hot water. However, since the CNG Tower does not consume a significant amount of domestic hot water, this 


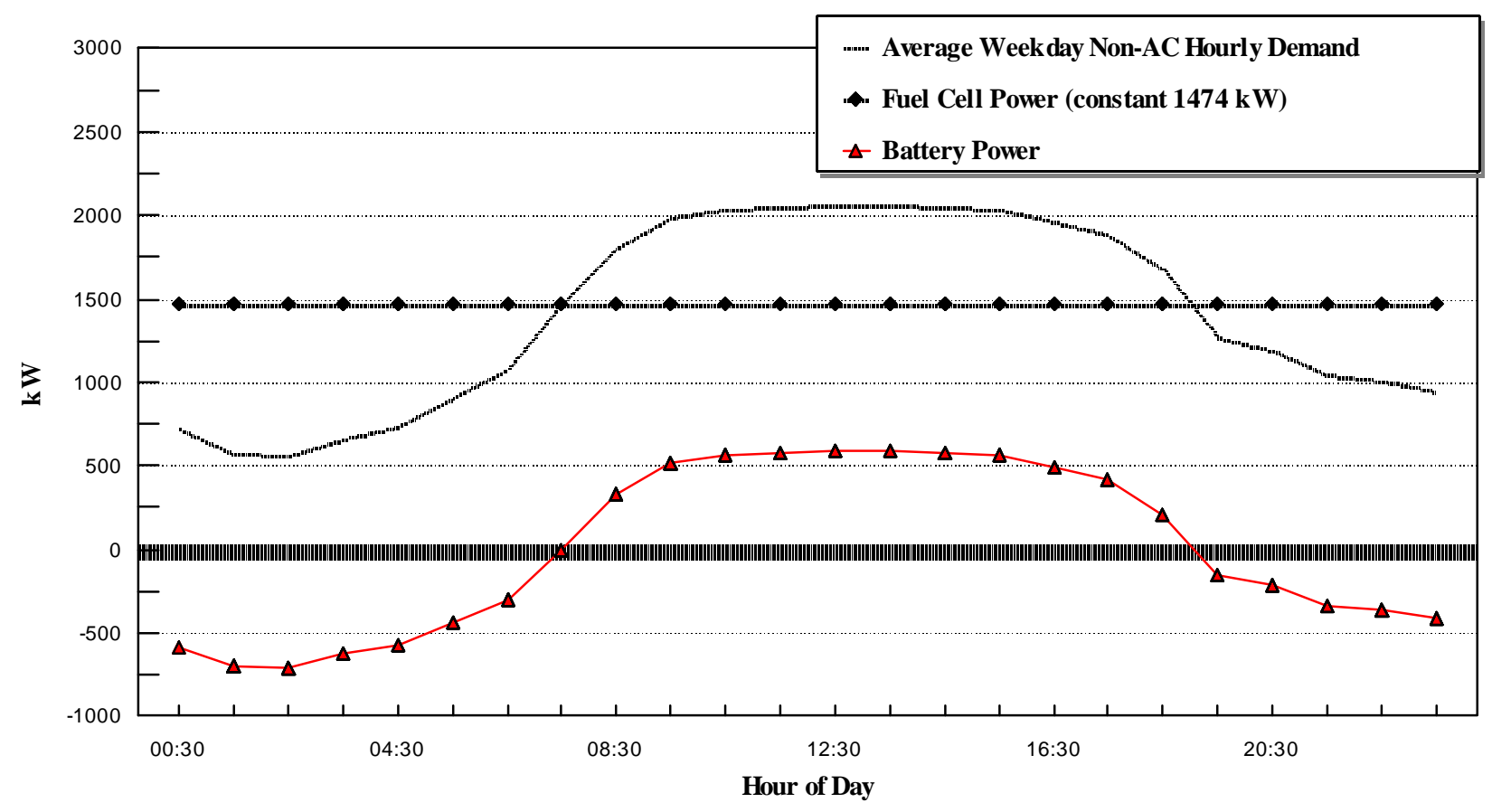

Figure 22. Average Non-AC Weekday Demand Met by the Average Load System Fuel Cell Capacity $=1500 \mathrm{~kW}$; Maximum Battery Power $=568 \mathrm{~kW}$

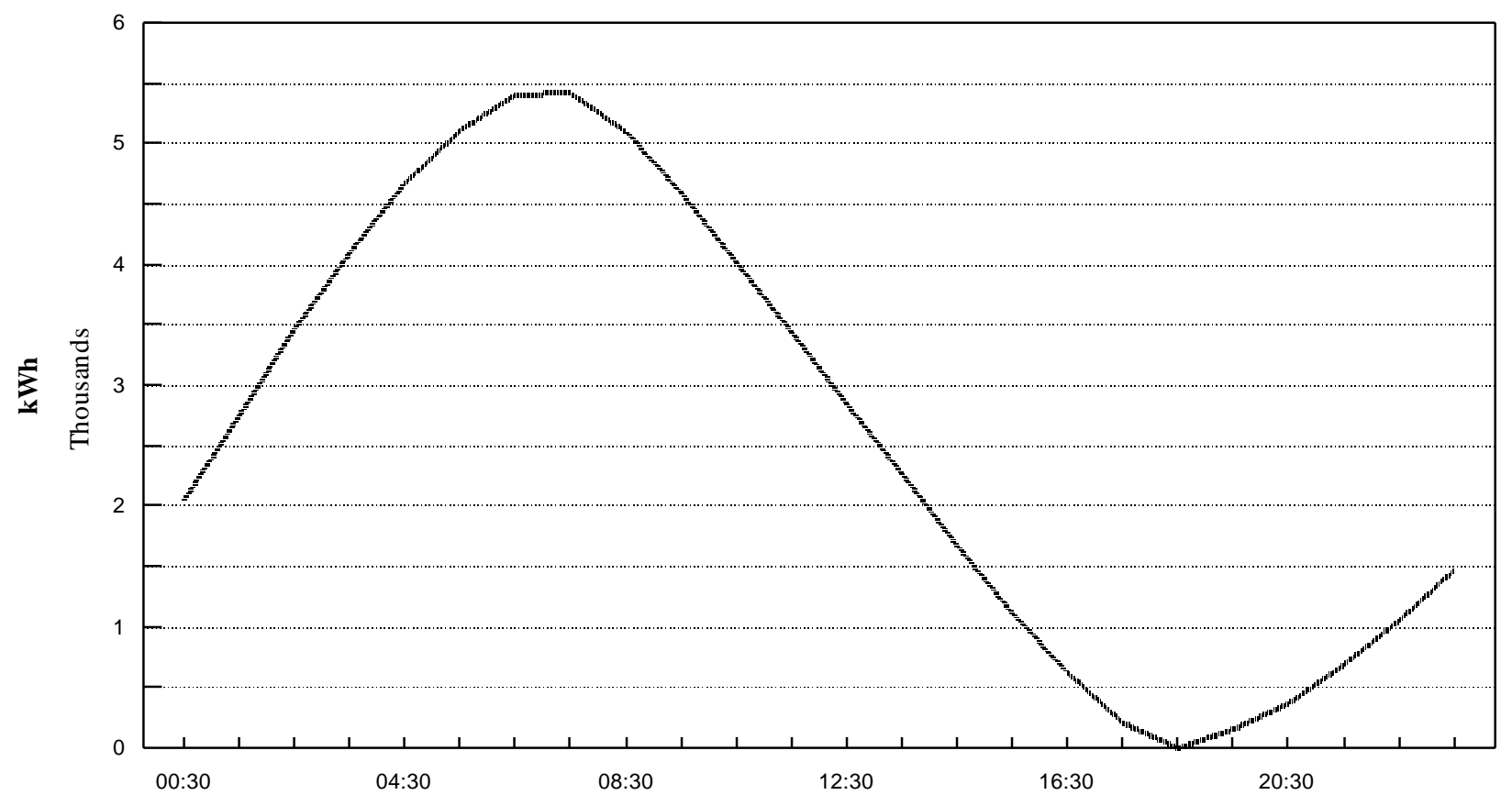

Figure 23. Battery Storage Profile During an Average Weekday DC-DC Round-Trip Efficiency $=0.78$; Battery Storage $=5425 \mathrm{kWh}$ 


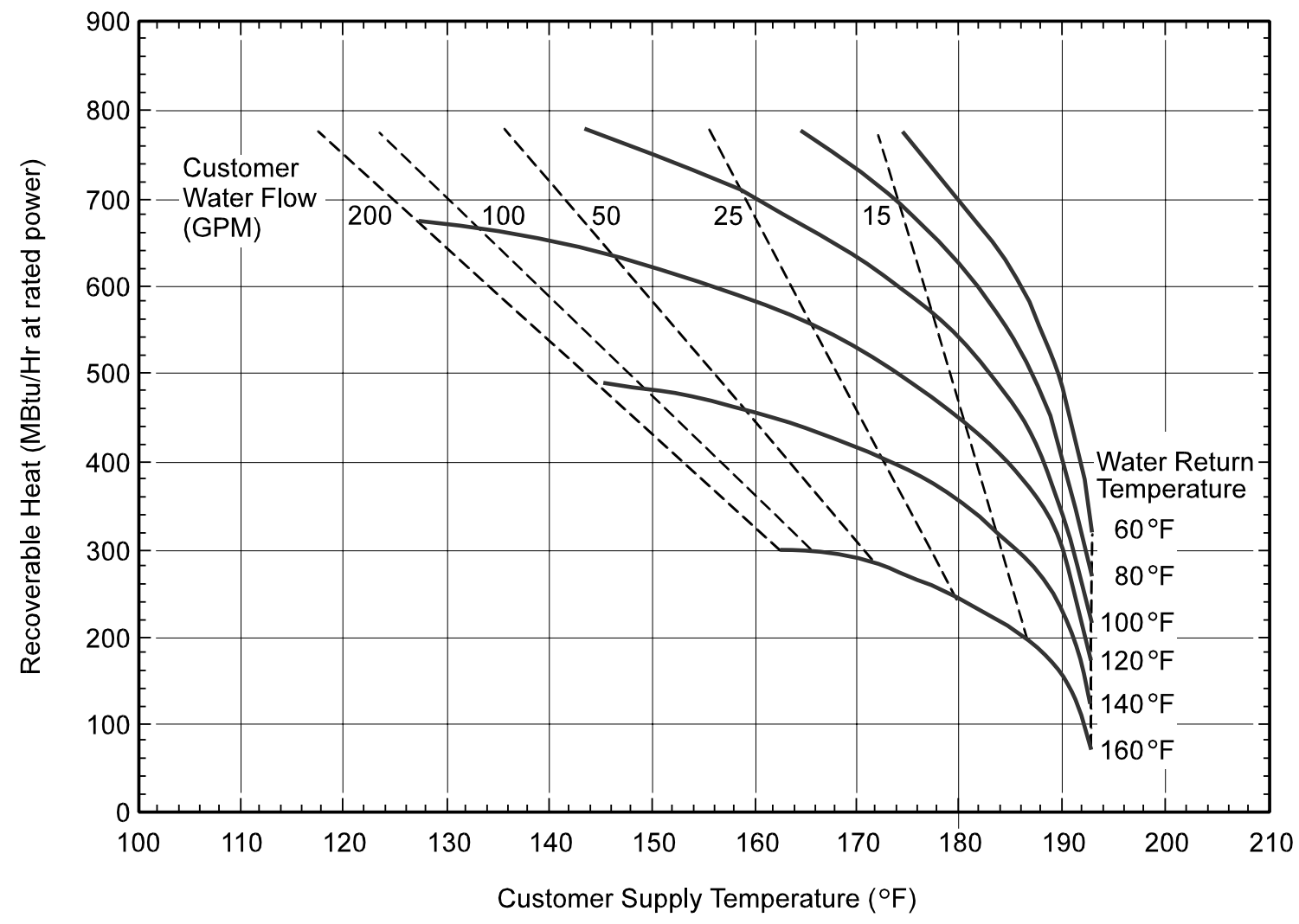

Figure 24. ONSI PC25 Fuel Cell Reject Heat Availability

Source: ONSI Corporation

application was not considered in this study. Consequently, all of the PAFC's $140{ }^{\circ} \mathrm{F}$ reject heat was assumed to be rejected to the atmosphere via the cooling tower.

Space Heating Equipment. As was shown in Section 2, the CNG Tower would require 6.0 MMBtu/hr of space heating if the outside temperature dropped to an extreme of $0{ }^{\circ} \mathrm{F}$. Together, the two existing natural gas boilers could easily supply this heat rate. However, it may be more economical to supply some of the space heating with heat rejected from the fuel cell. The typical supply temperature, $180^{\circ} \mathrm{F}$, of the hot water used for space heating in the CNG Tower is sufficiently low to accept all the heat, up to $350,000 \mathrm{Btu} / \mathrm{hr}$, rejected from the fuel cell's high-grade, $250^{\circ} \mathrm{F}$, heat exchanger. Unfortunately, none of the three, different sized fuel cells considered in this study would reject enough heat to satisfy the $0{ }^{\circ} \mathrm{F}$ extreme space heating demand. At maximum output, the peak, 2800 and $2700 \mathrm{~kW}$; average, $1500 \mathrm{~kW}$; and base, $600 \mathrm{~kW}$, load system fuel cells reject only 4.9, 4.72, 2.62, and 1.05 MMBtu/hr, respectively. Therefore, for all the cogeneration systems considered in this study, the existing natural gas boilers are retained to supply any space heating that cannot be provided with heat rejected from the fuel cell.

The temperature of the water from which the heat is available from the ONSI PC25C presumably could be raised to $180^{\circ} \mathrm{F}$ by mixing the $250^{\circ} \mathrm{F}$ and $140{ }^{\circ} \mathrm{F}$ streams. Such a measure, 
however, would not be effective for heating the building because the hot water return temperature, $150{ }^{\circ} \mathrm{F}$ or higher, is significantly above the $140{ }^{\circ} \mathrm{F}$ temperature at which heat is available from the fuel cell's low-grade heat exchanger. A more detailed consideration of both the ONSI cogeneration system design and operation and also of the required response of the heating system to varying temperatures during the course of a day is required to determine how varying power and heat loads might most effectively be accommodated by the cogeneration system.

Air Conditioning Equipment. As shown in Section 2, the CNG Tower would require 730 tons of air conditioning if summer weather conditions rose to the extremes of $100{ }^{\circ} \mathrm{F}$ and 100 percent relative humidity. Although just one of the two existing 750-ton electric chillers could easily supply this maximum cooling rate, it may be economic to provide some air conditioning by using the heat rejected from the fuel cell to drive an absorption chiller. The coefficient of performance of commercially available, hot water-driven absorption chillers is about 0.7 Btu of heat removed per Btu supplied. ${ }^{3}$ Heat, in the form of hot water, must be supplied to the absorption chiller at or above $240{ }^{\circ} \mathrm{F}$. Typically, the hot water will exit the absorption chiller at $224{ }^{\circ} \mathrm{F}$ and be reheated and recycled back to the absorption chiller. The required entry/exit temperatures of the hot water flow through the absorption chiller are sufficiently low to accept all the heat (up to $350,000 \mathrm{Btu} / \mathrm{hr}$ ) rejected from the fuel cell's high grade, $250{ }^{\circ} \mathrm{F}$ heat exchanger. Unfortunately, the heat rejected from the fuel cell's low grade heat exchanger is too cool, $140{ }^{\circ} \mathrm{F}$, for use by the absorption chiller. These absorption chillers also require an electrical input of $0.15 \mathrm{~kW} /$ ton to operate their pumps and auxiliary equipment -- much less than $0.79 \mathrm{~kW} /$ ton required by the existing electric chillers. Despite their lower power requirement, other factors, such as capital, operating and maintenance costs, must be considered to determine whether installing absorption chillers is economic. These factors will be assessed in Section 4.2.

As detailed below, none of the fuel cell systems -- peak, average or base load -- considered in this study rejected enough heat to drive an absorption chiller large enough to meet the maximum air conditioning demand of 730 tons. If it were imperative to meet the maximum air conditioning load with only absorption chillers, natural gas could be burned to make up the deficit of fuel cell heat. However, since the CNG Tower already has electric chillers installed, it is more economical to retain them and size the absorption chiller to run using only the heat rejected by the fuel cell.

At maximum output, the $2700 \mathrm{~kW}$ fuel cell in the peak load system would reject $4.7 \mathrm{MMBtu} /$ hr of high grade, $250^{\circ} \mathrm{F}$ heat; enough to drive a 275-ton absorption chiller. A 273-ton, hot water-driven, absorption chiller is commercially available from York International. York also offers several smaller units -- 235, 205, 172, and 155 tons -- their smallest being 120 tons. To determine which size of absorption chiller operated most economically with the $2700 \mathrm{~kW}$ fuel cell, the performance of the peak load system was modeled on an hourly basis using each of the six absorption chillers mentioned above.

${ }^{3}$ Steam-driven absorption chillers have much better coefficients of performance, approaching 1.2. The relatively low temperatures at which heat is available from the PC25C limited this study to hot water-driven units. Converting the hot water to steam via supplementary firing with natural gas was not considered in this study. 
The model was executed using historical electric power and air conditioning demand data from 16 weekdays which required air conditioning in 1993. For each hour of each day, the heat rejected from the peak load system fuel cell was used to generate air conditioning with an absorption chiller. The amount of air conditioning generated in each hour was limited by either the heat available from the fuel cell, the size of the absorption chiller, or the hourly air conditioning demand. None of the fuel cell heat was stored; it was either immediately used by the absorption chiller or rejected via the cooling tower. For each day, the total amount of air conditioning supplied by the absorption chiller was calculated as a percentage of that day's total air conditioning requirement.

The results, shown in Figure 25, indicate that the 205-ton and 273-ton absorption chillers accomplished nearly the same amount of air conditioning. Therefore, the largest absorption chiller that was considered for the peak load system was 205 tons. The 120-ton chiller, the smallest available, was also considered. As shown in Figure 25, the 120-ton unit can supply around 18 percent of the total air conditioning demand on those days which require the most cooling.

Curves were fitted through the performance data in Figure 25 for the 205- and 120-ton units. The equations for these curves, which are listed in Appendix D, Table D-2, were used to calculate the performance of these two absorption chillers for each day of 1993. Based on this full analysis, the 205-ton unit was disqualified for economic reasons. See Figure 34a and the discussion in Section 4.2

The same approach was used to model the peak load system using data from 12 Saturdays and Sundays which required air conditioning. As shown by Figure 26, none of the various sized absorption chillers can be expected to supply an appreciable amount of air conditioning on the weekend.

At maximum output, the $1500 \mathrm{~kW}$ fuel cell in the average load system would reject 2.62 MMBtu/hr of high grade, $250{ }^{\circ} \mathrm{F}$ heat, enough to drive a 153-ton absorption chiller. As mentioned above, a 155-ton, hot water-driven, absorption chiller is commercially available from York International, as well as a smaller, 120-ton unit. To determine which of these two absorption chillers best matched the $1500 \mathrm{~kW}$ fuel cell, the performance of the average load system was modeled on an hourly basis using each of them. The modeling method was the same as that described above for the peak load system, with the important exception that the fuel cell in the average load system was operated at constant output while the peak load system fuel cell followed the electric demand. The results, shown in Figure 27, indicate that the 155-ton absorption chiller can supply around 28 percent of the total air conditioning demand on those days which require the most cooling. The 120 -ton absorption chiller can supply around 22 percent of the total air conditioning demand on those days which require the most cooling.

Curves were fitted through the performance data in Figure 27 for the 155- and 120-ton units. The equations for these curves, which are listed in Appendix D, Table D-2, were used to calculate 


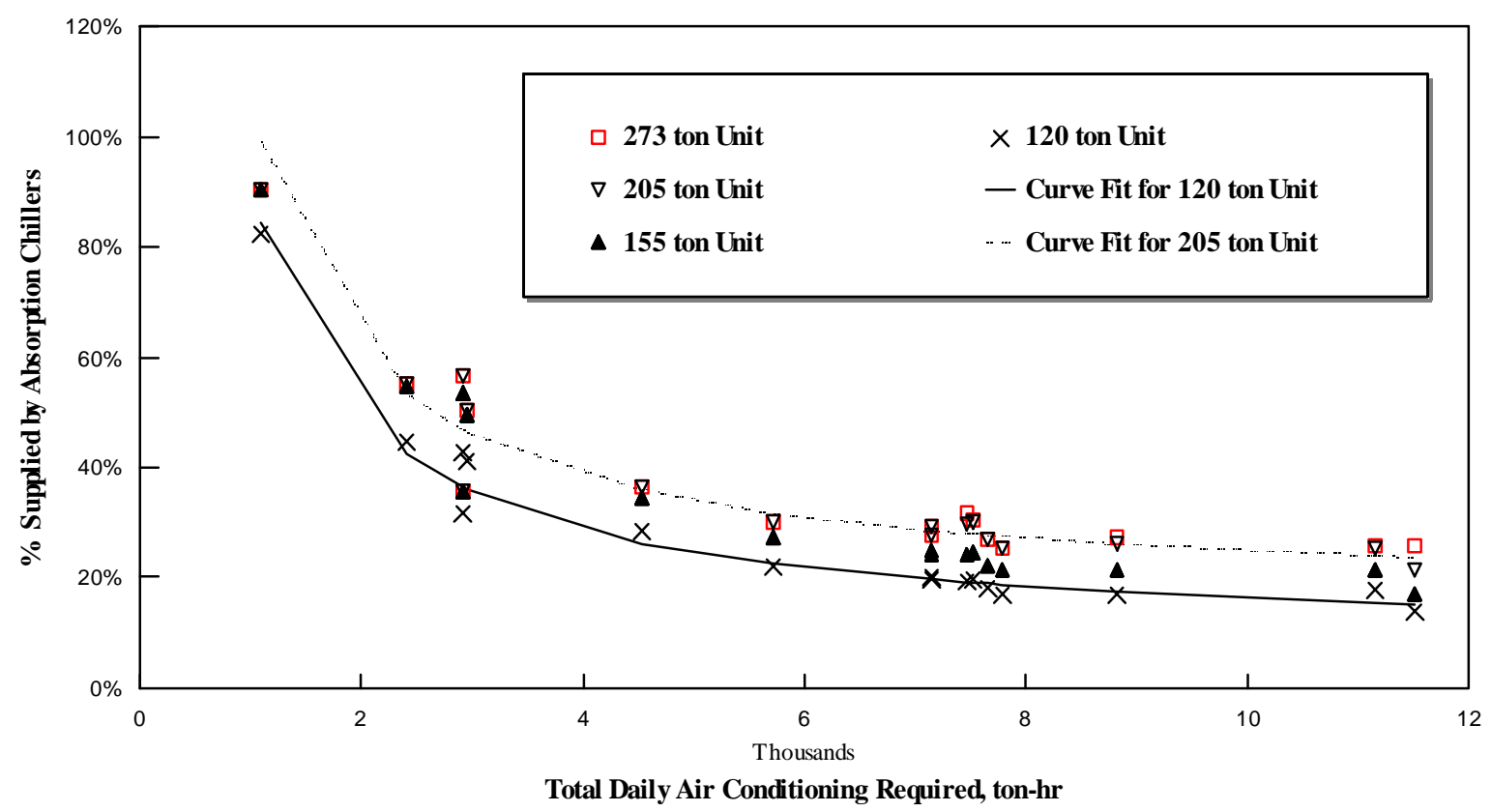

Figure 25. Weekday AC Supplied by Peak Load System Absorption Chiller For 16 Weekdays on an Hourly Basis (Hourly Chiller Output is Based on Hourly Fuel Cell Heat Rejection)

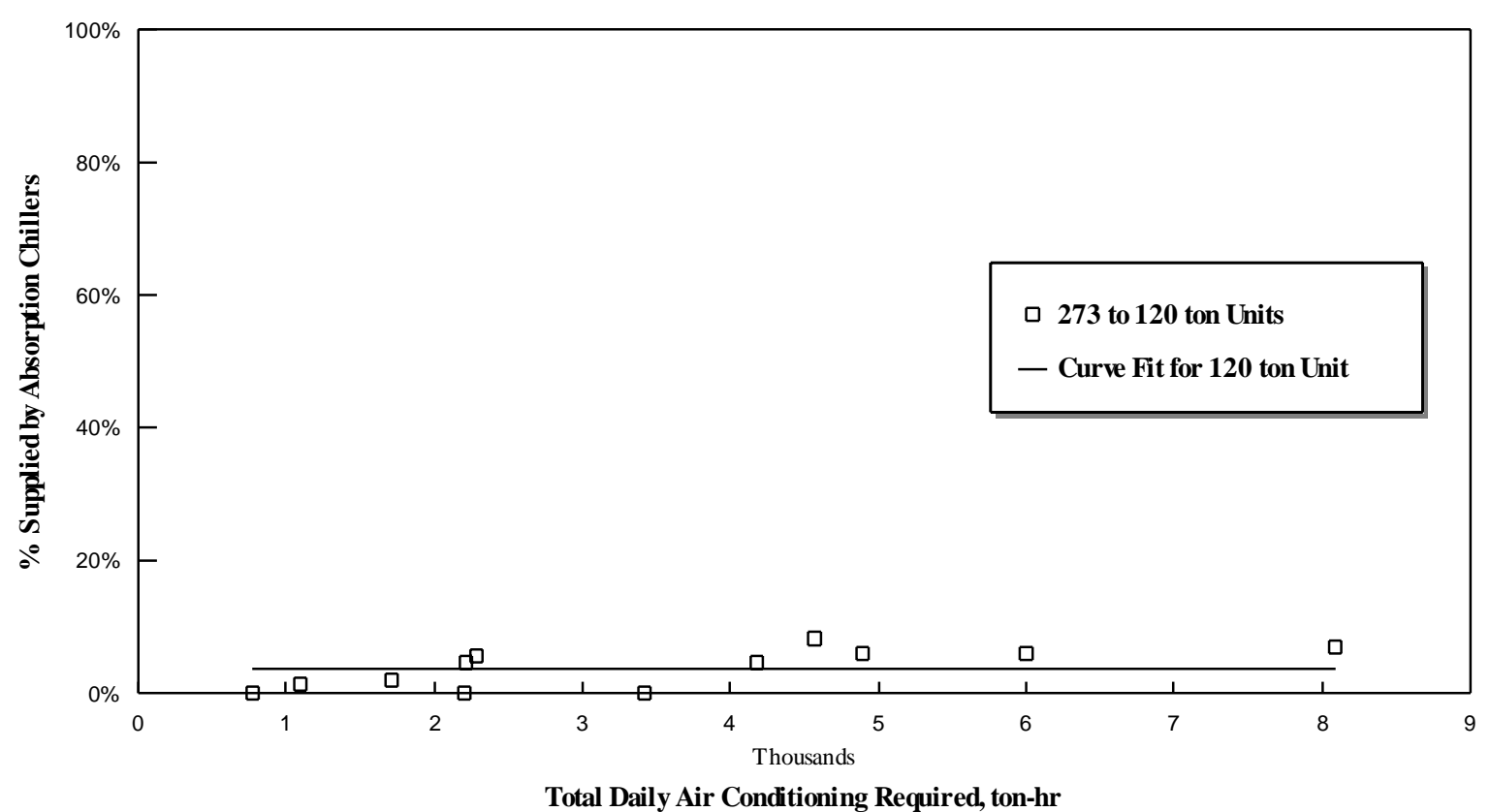

Figure 26. Weekend AC Supplied by Peak Load System Absorption Chiller For 12 Saturdays and Sundays on an Hourly Basis (Hourly Chiller Output is Based on Hourly Fuel Cell Heat Rejection) 


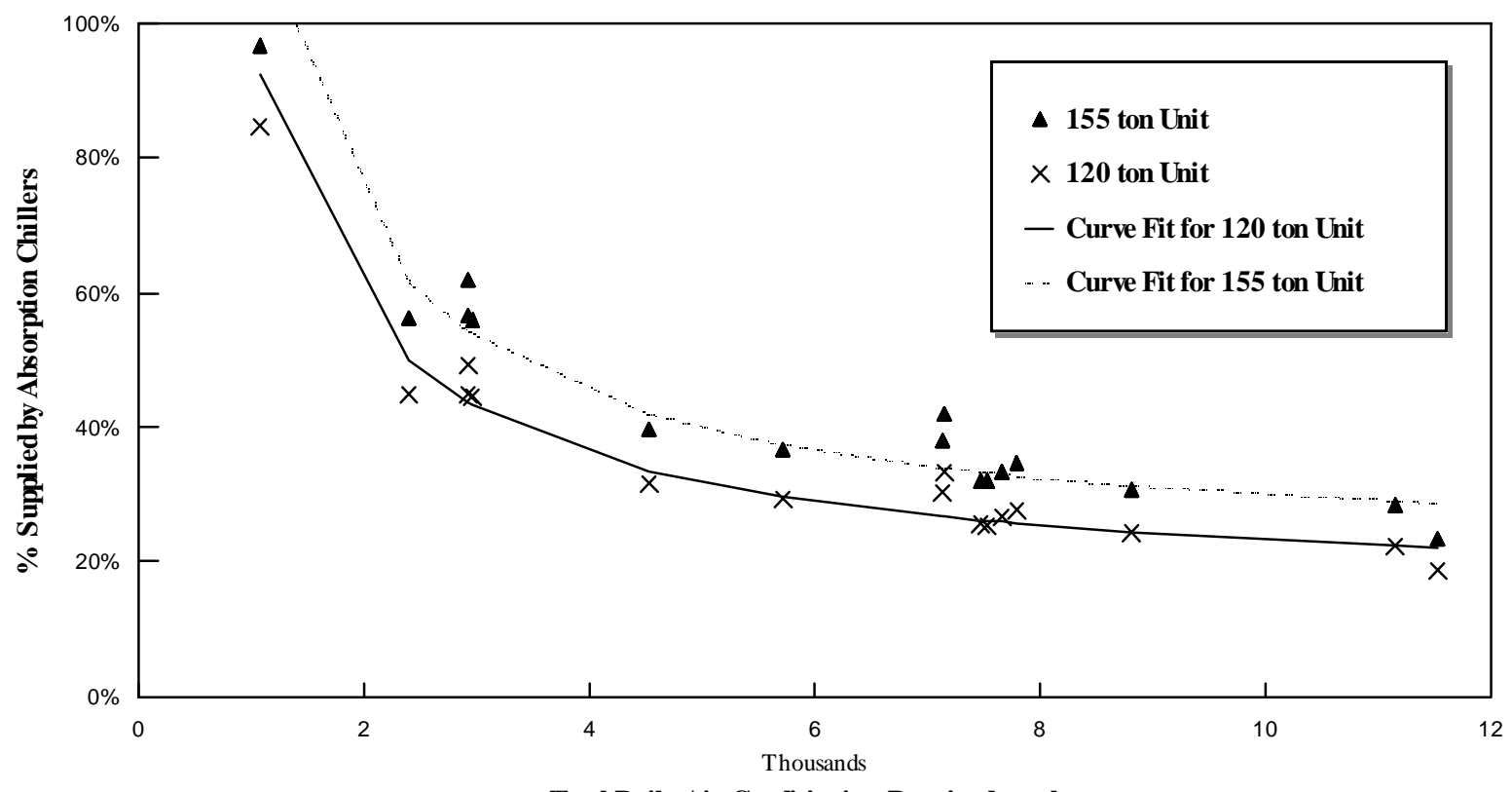

Total Daily Air Conditioning Required, ton-hr

Figure 27. Weekday AC Supplied by Average Load System Absorption Chiller For 16 Weekdays on an Hourly Basis (Hourly Chiller Output is Based on Hourly Fuel Cell Heat Rejection)

the performance of these two absorption chillers for each day of 1993. Based on this full analysis, the 155 -ton unit was determined to be preferable for economic reasons. See Figure $34 \mathrm{~b}$ and the discussion in Section 4.2.

The same approach was used to model the average load system using data from 12 Saturdays and Sundays which required air conditioning. As shown by Figure 28, both the 155- and 120-ton absorption chillers supplied nearly the same amount of air conditioning. However, the percentage of daily air conditioning which is supplied by the absorption chiller is apparently independent of the total daily air conditioning required. According to Figure 28, the average load system with a 155-ton absorption chiller would always provide close to 20 percent of the total daily air conditioning required on any Saturday or Sunday.

At maximum output, the $600 \mathrm{~kW}$ fuel cell in the base load system would reject $1.05 \mathrm{MMBtu} /$ $\mathrm{hr}$ of high-grade, $250^{\circ} \mathrm{F}$ heat; enough to drive a 61-ton absorption chiller. This is much smaller than any of the units found to be commercially available. Furthermore, such a small unit could most likely not justify its capital and installation costs. For these reasons, no further consideration was given to equipping the base load system with an absorption chiller.

Heat Rejection Equipment. The heat rejected from the cooling tower comes from various sources:

- The heat removed by the air conditioning system from the building, $\mathrm{Q}_{\mathrm{AC}}$; 


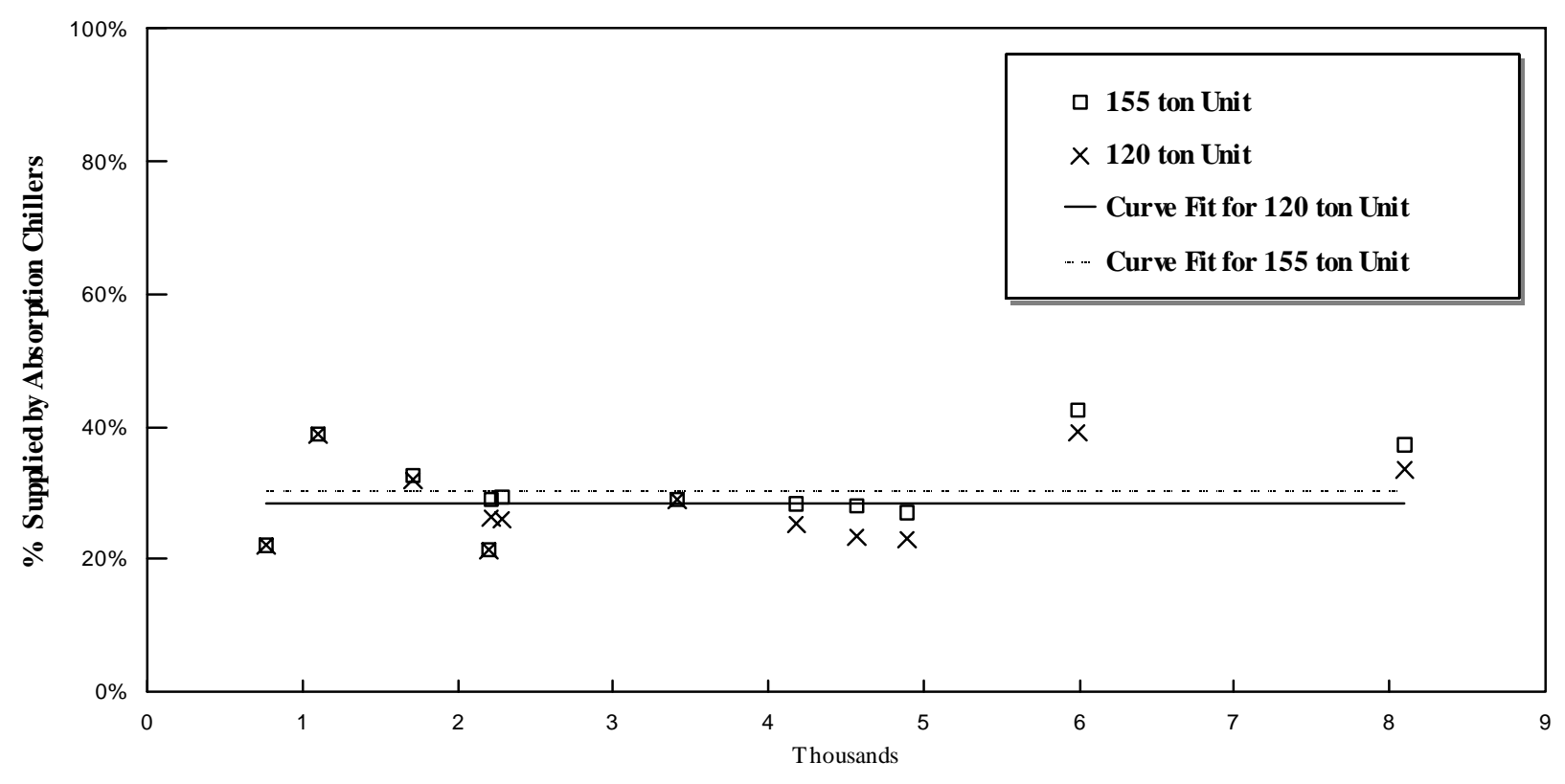

Total Daily Air Conditioning Required, ton-hr

Figure 28. Weekend AC Supplied by Average Load System Absorption Chiller For 12 Saturdays and Sundays on an Hourly Basis (Hourly Chiller Output is Based on Hourly Fuel Cell Heat Rejection)

- The heat equivalent of the electrical energy, $0.79 \mathrm{~kW} /$ ton or $2696 \mathrm{Btu} / \mathrm{hr}$ ton, used to operate the electric chiller, $\mathrm{W}_{\text {Ele }}$;

- The heat equivalent of the electrical energy, $0.15 \mathrm{~kW} /$ ton or $512 \mathrm{Btu} / \mathrm{hr}$ ton, $\mathrm{W}_{\mathrm{Abs}}$; and the heat, 0.7 tons heat per ton cooling, $\mathrm{Q}_{\mathrm{Abs}}$, used to operate the absorption chiller; and

- The heat rejected by the fuel cell cogeneration system, $\mathrm{Q}_{\mathrm{FC}}$, equal to 60 percent of the energy in its natural gas fuel supply (the fuel cell is 40 percent efficient).

The heat used to drive the absorption chiller, $\mathrm{Q}_{\mathrm{Abs}}$ comes solely from heat which is rejected from the fuel cell, $\mathrm{Q}_{\mathrm{FC}}$; therefore, to keep the accounting straightforward, $\mathrm{Q}_{\mathrm{FC}}$ is retained and $\mathrm{Q}_{\mathrm{Abs}}$ is set equal to zero.

For any of the fuel cell systems, the rate of heat rejection reaches a maximum when the air conditioning demand is at its peak, 730 tons or $8.8 \mathrm{MMBtu} / \mathrm{hr}$, and the fuel cell is operating at its maximum capacity. For example, the maximum amount of heat which could be rejected by the $2700 \mathrm{~kW}$ peak load system, $\mathrm{Q}_{2700}$, can be calculated as follows. The peak air conditioning demand is shared between the 120-ton absorption chiller and the electric chillers.

$$
\begin{aligned}
\mathrm{Q}_{2700}= & \mathrm{Q}_{\mathrm{AC}}+\mathrm{W}_{\mathrm{Ele}}+\mathrm{W}_{\mathrm{Abs}}+\mathrm{Q}_{\mathrm{Abs}}+\mathrm{Q}_{\mathrm{FC}} \\
\mathrm{Q}_{2700}= & {[8.8 \mathrm{MMBtu} / \mathrm{hr}]+[(2696 \mathrm{Btu} / \mathrm{hr} \text { ton })(610 \text { tons })(1 \mathrm{E}-6 \mathrm{MMBtu} / \mathrm{Btu})] } \\
& +[(512 \mathrm{Btu} / \mathrm{hr} \text { ton })(120 \text { tons })(1 \mathrm{E}-6 \mathrm{MMBtu} / \mathrm{Btu})]+[0] \\
& +[(1-0.4)(2700 \mathrm{~kW})(3413 \mathrm{Btu} / \mathrm{hr} \mathrm{kW})(1 \mathrm{E}-6 \mathrm{MMBtu} / \mathrm{Btu}) /(0.4)] \\
\mathrm{Q}_{2700}= & 8.8+1.64+0.061+0+13.8=24.3 \mathrm{MMBtu} / \mathrm{hr}
\end{aligned}
$$


Since the $2800 \mathrm{~kW}$ peak load system has a larger fuel cell, and since it relies solely on electric chillers for air conditioning, its maximum heat rejection rate is even larger:

$$
\begin{aligned}
\mathrm{Q}_{2800}= & \mathrm{Q}_{\mathrm{AC}}+\mathrm{W}_{\mathrm{Ele}}+\mathrm{W}_{\mathrm{Abs}}+\mathrm{Q}_{\mathrm{Abs}}+\mathrm{Q}_{\mathrm{FC}} \\
\mathrm{Q}_{2800}= & {[8.8 \mathrm{MMBtu} / \mathrm{hr}]+[(2696 \mathrm{Btu} / \mathrm{hr} \text { ton })(730 \mathrm{tons})(1 \mathrm{E}-6 \mathrm{MMBtu} / \mathrm{Btu})]+[0] } \\
& +[0]+[(1-0.4)(2800 \mathrm{~kW})(3413 \mathrm{Btu} / \mathrm{hr} \mathrm{kW})(1 \mathrm{E}-6 \mathrm{MMBtu} / \mathrm{Btu}) /(0.4)] \\
\mathrm{Q}_{2800}= & 8.8+1.97+0+0+14.3=25.1 \mathrm{MMBtu} / \mathrm{hr}
\end{aligned}
$$

Of all the fuel cell cogeneration systems considered in this study, it is clear that the $2800 \mathrm{~kW}$ peak load system is capable of rejecting heat at the highest rate. Fortunately, the existing cooling tower is capable of rejecting up to $30 \mathrm{MMBtu} / \mathrm{hr}$ of waste heat to the atmosphere. As shown above, this is sufficient to reject the waste heat generated by all of the fuel cell systems considered in this study.

Backup Power Equipment. The CNG Tower currently relies on an oil-fired diesel engine, 480 volt, 3 phase, $875 \mathrm{kVA}$, generator to provide $700 \mathrm{~kW}$ of backup power for the building's security and fire alarm systems, emergency lighting, fire pumps, smoke evacuation fans, and elevators.

For the average and base load systems, which would remain connected to the local electric utility, there may well be no need for the existing emergency backup power system. The probability of a simultaneous disruption in service from both the fuel cell and the utility is extremely remote. In addition, the average load system's battery storage might be sized to provide for backup power as well as for load leveling.

For the peak load system, which would likely be disconnected from the utility, the existing backup power system would be retained for use when service from the fuel cell was disrupted. 


\section{Cogeneration Systems Operations and Performance Analysis}

The natural gas fuel use by a PAFC cogeneration system and the use of auxiliary power purchased from a utility can be calculated based on:

- An assumed system capacity presented in Table 3,

- A system operational mode as described in Section 3.3,

- The equipment performance characteristics presented in Table 2,

- The power demand curves for the CNG Tower, Figures 8-12, and

- The weather data -- daily average temperature and humidity throughout the period.

The heat required daily for space heating in the CNG Tower is a function of the outside temperature as illustrated in Figures 14 and 19. U.S. Weather Bureau data on daily average temperatures in Pittsburgh over the course of a year, or specifically throughout the year 1993, can, therefore, be used to estimate the total daily heat requirements for space heating in the CNG Tower. And the specific information on the PAFC fuel cell cogeneration system, its operation, and the building electrical demands can be used then to determine the supplemental gas usage required to provide heat for space heating not supplied by reject heat from the fuel cell.

The heat and/or electrical energy required for air conditioning in the CNG Tower is a function both of the outside temperature and the relative humidity of the air as illustrated in Figures 18 and 19 and the air conditioning equipment descriptions in Table 2. Again, U.S. Weather Bureau data can be used to estimate the demand for heat removal from the CNG Tower by the combination of absorption and vapor compression chillers. The heat available for absorption chiller operation is known from the selected design parameters and operational mode of the PAFC power generation component. The supplemental electrical energy and power required for the vapor compression system can thus be determined.

\subsection{Results of Technical Performance Calculations}

Technical and economic performance calculations were performed for each day of 1993 to determine how much energy would be consumed by the CNG Tower's existing system, as well as each of the five fuel cell cogeneration systems, to meet the electrical and HVAC requirements of the building for that year. Appendix D describes these technical calculations in detail, listing the assumptions which were made, and citing the equations which were used. The results are presented in Table 4, which contains a detailed accounting of each system's energy consumption. 
Table 4. Annual Performance Summary for Existing and Fuel Cell Retrofit Systems

\begin{tabular}{|c|c|c|c|c|c|c|}
\hline & $\begin{array}{l}\text { Existing } \\
\text { System }\end{array}$ & $\begin{array}{c}\text { Peak } \\
\text { Load } \\
\text { Retrofit }\end{array}$ & $\begin{array}{l}\text { Peak Load } \\
\text { Retrofit With } \\
\text { 120-Ton } \\
\text { Absorption } \\
\text { Chiller }\end{array}$ & $\begin{array}{l}\text { Average } \\
\text { Load } \\
\text { Retrofit }\end{array}$ & $\begin{array}{l}\text { Average Load } \\
\text { Retrofit With } \\
\text { 155-Ton } \\
\text { Absorption } \\
\text { Chiller }\end{array}$ & $\begin{array}{c}\text { Base Load } \\
\text { Retrofit }\end{array}$ \\
\hline \multicolumn{7}{|l|}{ Space Heating Accomplished } \\
\hline By Natural Gas-Fired Boiler, GJ & 10152 & 6895 & 7046 & 3401 & 3401 & 5436 \\
\hline By Fuel Cell Reject Heat, GJ & N/A & 3257 & 3106 & 6751 & 6751 & 4716 \\
\hline Total, GJ & 10152 & 10152 & 10152 & 10152 & 10152 & 10152 \\
\hline \multicolumn{7}{|l|}{ Air Conditioning Accomplished } \\
\hline By Electric Chiller, GJ & 11183 & 11183 & 8786 & 11183 & 7006 & 11183 \\
\hline By Absorption Chiller, GJ & N/A & N/A & 2397 & N/A & 4177 & N/A \\
\hline Total, GJ & 11183 & 11183 & 11183 & 11183 & 11183 & 11183 \\
\hline \multicolumn{7}{|l|}{ Electricity Usage } \\
\hline MWh Consumed by Electric Chillers & 698 & 698 & 548 & 698 & 437 & 698 \\
\hline MWh Consumed by Absorption Chiller & N/A & N/A & 28 & 48 & 48 & N/A \\
\hline Non-A.C. MWh Required & 10876 & 10876 & 10876 & 10876 & 10876 & 10876 \\
\hline Total MWh Required & 11574 & 11574 & 11452 & 11574 & 11361 & 11574 \\
\hline MWh Purchased from Utility & 11574 & 0 & 0 & 633 & 437 & 6339 \\
\hline Sum of 12 Monthly Utility Peak Demands, kW & 28773 & 0 & 0 & 4269 & 3154 & 21573 \\
\hline MWh Generated by Fuel Cell & N/A & 11574 & 11452 & 11357 & 11337 & 5235 \\
\hline MWh Battery Losses & N/A & N/A & N/A & 416 & 413 & N/A \\
\hline \multicolumn{7}{|l|}{ Natural Gas Usage } \\
\hline By Boilers for Space Heating, MCF & 11455 & 7780 & 7950 & 3837 & 3837 & 6134 \\
\hline By Fuel Cell, MCF & N/A & 103951 & 102855 & 102007 & 101823 & 47020 \\
\hline Total, MCF & 11455 & 111731 & 110805 & 105844 & 105660 & 53154 \\
\hline \multicolumn{7}{|l|}{ Primary Energy Consumed } \\
\hline Space Heating, GJ & 11482 & 7798 & 7969 & 3846 & 3846 & 6148 \\
\hline Air Conditioning, GJ & 7855 & 6284 & 5185 & 7708 & 5350 & 7855 \\
\hline Non-A.C. Electricity, GJ & 122388 & 97910 & 97910 & 97910 & 97910 & 110606 \\
\hline Battery Losses, GJ & N/A & N/A & N/A & 3745 & 3718 & N/A \\
\hline Total, GJ & 141725 & 111992 & 111064 & 113209 & 110824 & 124609 \\
\hline
\end{tabular}


Electrical Energy, Utility Purchases. As shown in Figure 29, all of the fuel cell cogeneration retrofit systems reduce both the peak monthly electricity demand $(\mathrm{kW})$ and the monthly electricity consumption $(\mathrm{kWh})$. The total annual consumption of electricity for non-air conditioning purposes was 10,876 MWh. In addition to the non-air conditioning electricity, each cogeneration system would consume different amounts of electricity for air conditioning. The existing system purchased all of its electricity, 11,574 MWh, from the utility. Without absorption chillers the peak, average and base load retrofit cogeneration systems reduced the total annual consumption of utility kWh by 100, 95, and 45 percent, respectively. With absorption chillers, the peak and average load cogeneration systems reduced the total consumption of utility kWh by 100 and 96 percent, respectively.

The peak load capacity system totally eliminates both the consumption and demand utility charges, leaving perhaps only a backup power charge. The average load retrofit reduces each monthly demand peak by $2068 \mathrm{~kW}$, the combined capacities of the average load fuel cell, $1500 \mathrm{~kW}$, and the battery, $568 \mathrm{~kW}$. With absorption chilling, the average load retrofit further reduces each monthly demand peak since absorption chillers use less power than the alternative electric chillers. The base load retrofit reduces each monthly peak by $600 \mathrm{~kW}$.

Space Heating, Natural Gas Use. The total annual space heating requirement in 1993 was 10,152 gigajoules (GJ). The existing system accomplished this by burning 11,455 MCF of natural gas in the boiler. When absorption chillers were not used, heat rejected from the peak, average, and base load fuel cell systems provided 32, 67, and 46 percent of the total annual space heating requirement, respectively. ${ }^{4}$ Since space heating and air conditioning are occasionally required simultaneously at intermediate outside temperatures, the peak load system which had a 120 -ton absorption chiller used some of the fuel cell's reject heat for air conditioning instead of space heating, slightly reducing the percentage of annual space heating supplied by reject heat to 31 percent. The addition of a 155-ton absorption chiller to the average load system did not affect the percentage of space heating accomplished by heat rejected from fuel cell, 67 percent. All the retrofit fuel cell systems met the balance of the space heating by burning natural gas in the boiler as indicated in Figure 30.

Although each retrofit fuel cell system reduces the amount of natural gas used for space heating, overall consumption of natural gas is markedly increased as indicated in Figure 31 since the fuel cell consumes gas to generate electrical power.

Air Conditioning. The total annual air conditioning requirement in 1993 was 11,183 GJ. The existing system and all the fuel cell retrofit systems without an absorption chiller accomplished

${ }^{4}$ Although smaller in size, the base load and average load systems rejected more heat than the peak load system because they operated above 50 percent of their capacity (where reject heat is available) more often. See Table 1. However, the decrease in available heat from the peak load system is dependent on the particulars of the design and operation of the system. If the system as a whole is operated off peak at part load, then heat availability is as indicated above. Alternatively, if portions of the peak load system could be "switched off" at part load and the balance of the system operated at or near full load, then more heat would be available from the peak load systems than is available from the base load and average load systems. 


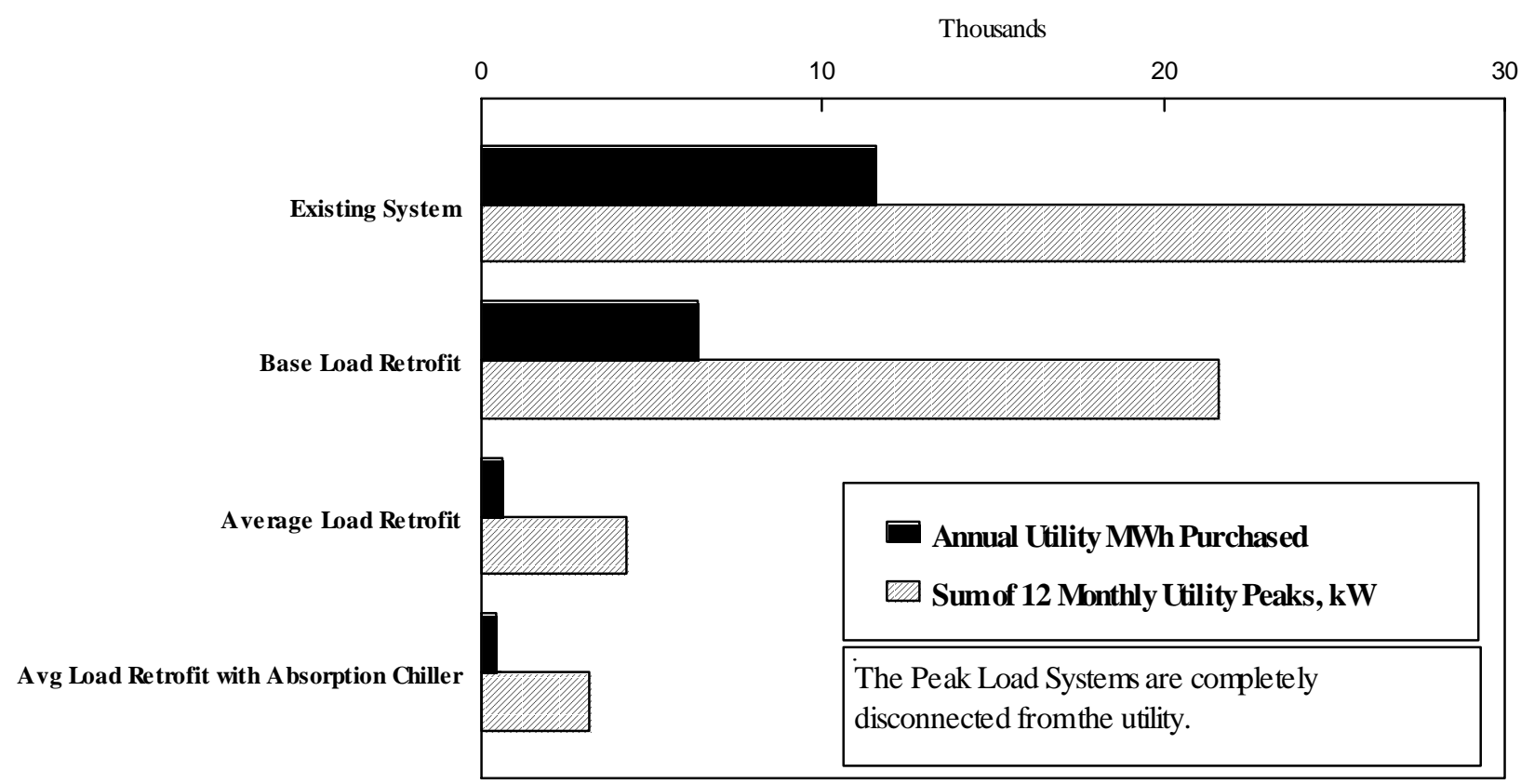

Figure 29. Purchases from the Electric Utility by the Existing and Retrofit Systems

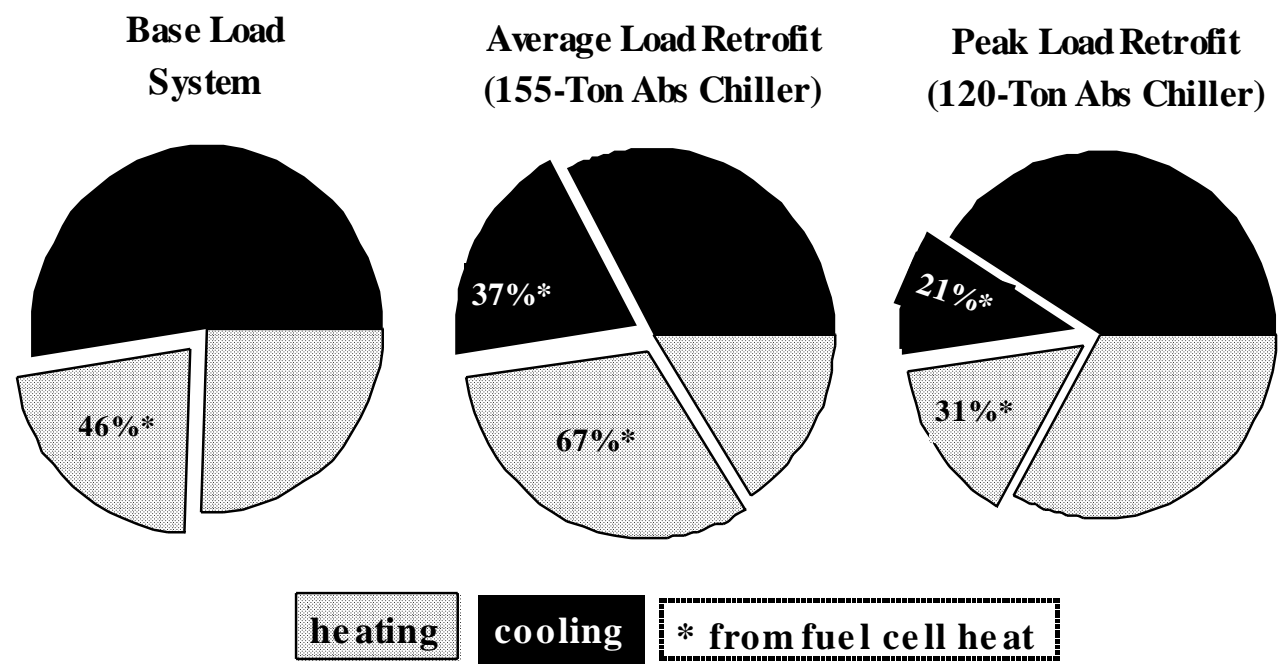

Figure 30. Fraction of Annual Space Heating and Air Conditioning Supplied from Fuel Cell Heat 


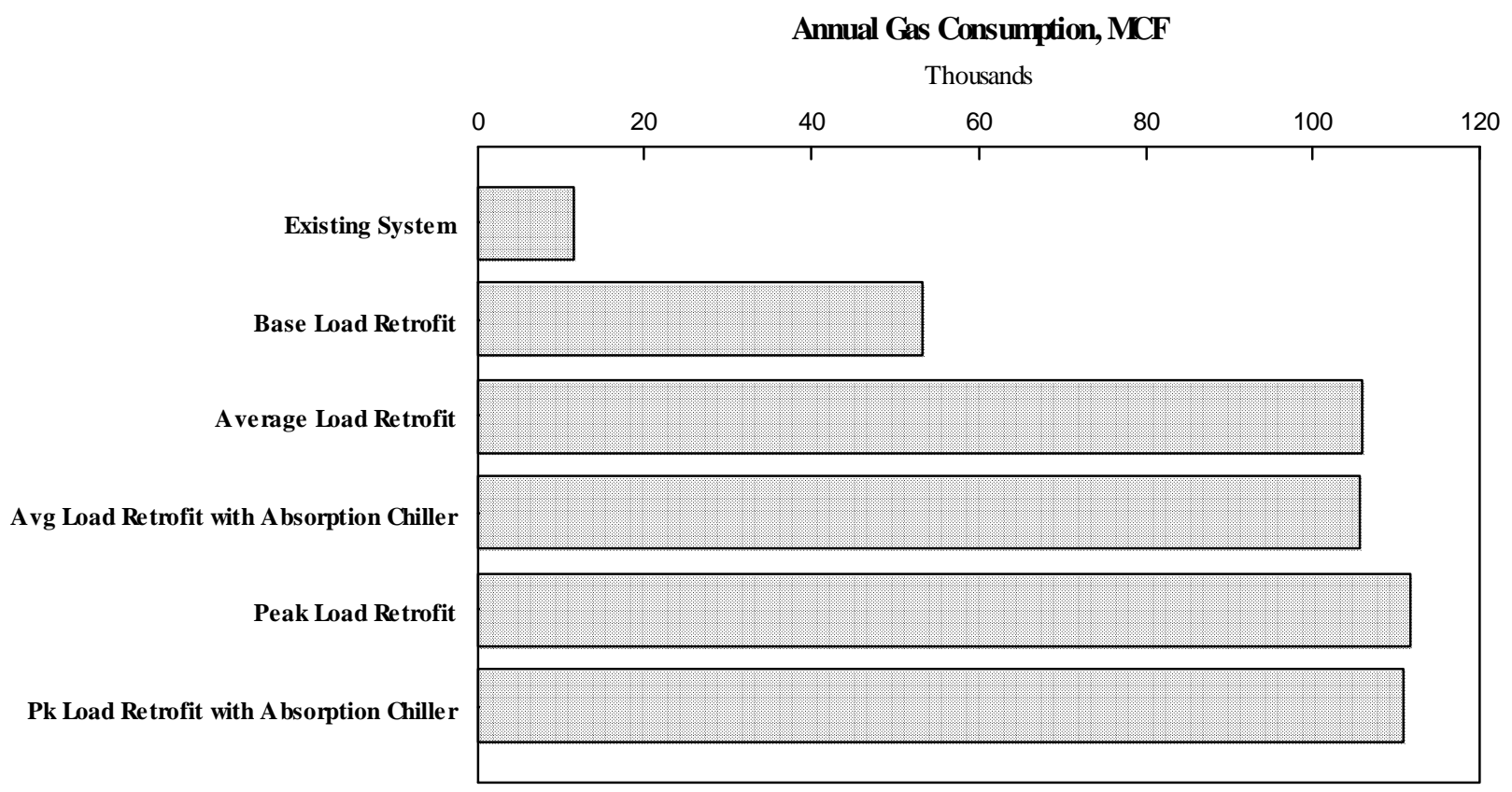

Figure 31. Purchases from the Gas Utility by the Existing and Retrofit Systems

this solely with the electric chiller, consuming $698 \mathrm{MWh}$. When equipped with 155-ton and 120-ton absorption chillers, the average and peak load systems utilized reject heat to provide 37 and 21 percent of the total annual air conditioning requirement, respectively ${ }^{5}$ as indicated in Figure 30. In comparison with the existing system, the absorption chillers allowed the average and peak load systems to consume 31 and 17 percent less kWh for air conditioning, respectively.

\subsection{Results of Economic Performance Calculations, Annual Energy Cost Savings}

The annual energy cost savings achieved by each of the five retrofit fuel cell cogeneration systems, compared to the existing system, depend on the rates of electricity and natural gas. Figures 32a, 32b, and 32c illustrate this relationship for the peak, average, and base load systems, respectively. Figures $32 \mathrm{a}$ and $32 \mathrm{~b}$ contain two cases each, with and without an absorption chiller. Operating and maintenance (O\&M) costs for the fuel cell, absorption chiller, and batteries were considered. ${ }^{5}$ Based on information provided by the ONSI Corporation, the fuel cell O\&M, which includes stack replacement, is estimated at $\$ 131 / \mathrm{kW}$-year. The absorption chiller O\&M is estimated at \$16/ton-year, based on information from a commercial vendor. Based on an EPRI report (3), the O\&M for the battery storage system was estimated at $\$ 8.1 / \mathrm{kWh}$ (storage)-year. All values are in 1996 dollars.

${ }^{5}$ The floor space which the fuel cell retrofit system would occupy could perhaps be otherwise leased. This opportunity cost was neglected in this study. 


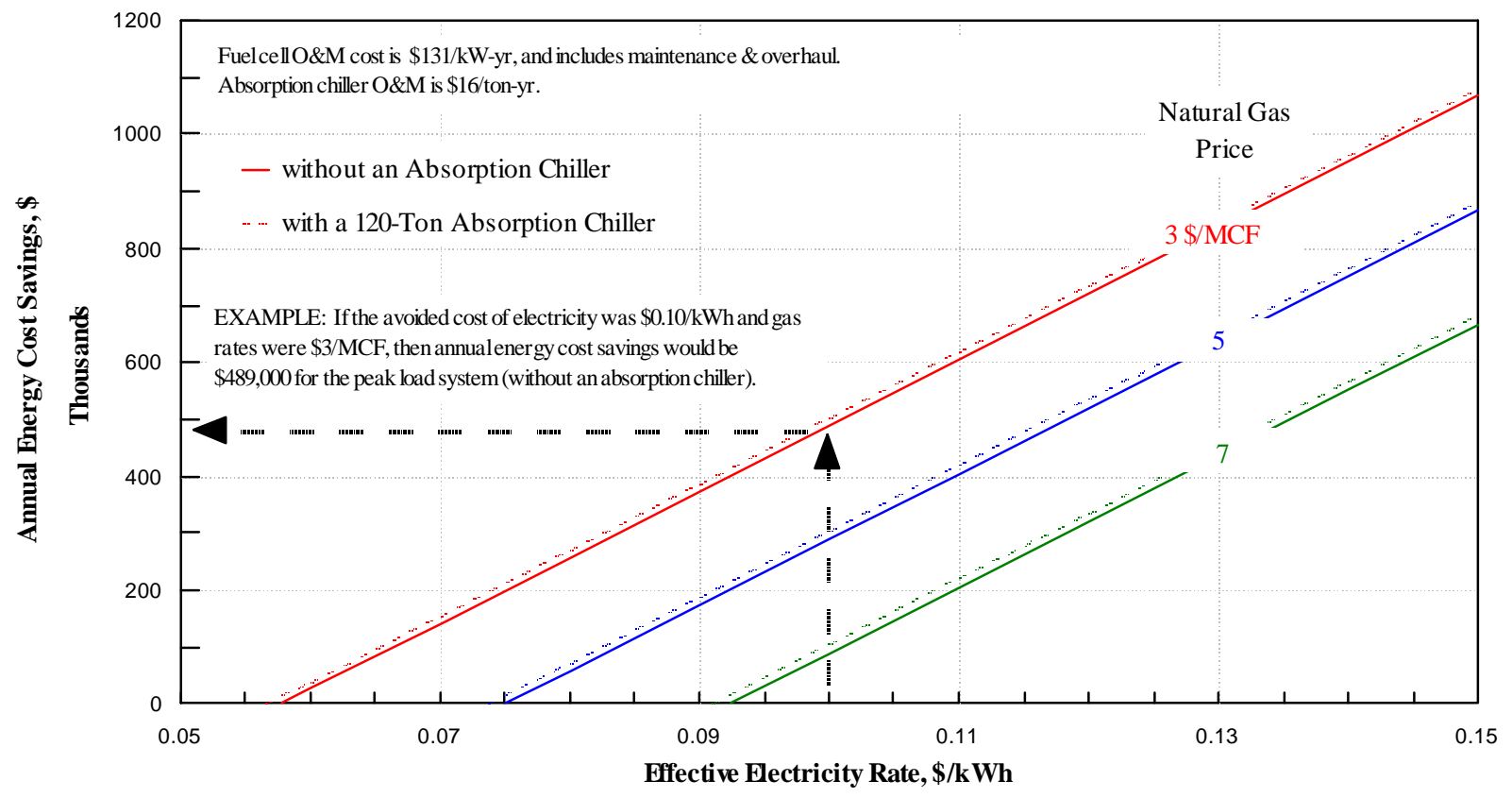

Figure 32a. Annual Energy Cost Savings for the CNG Tower Peak Load Systems

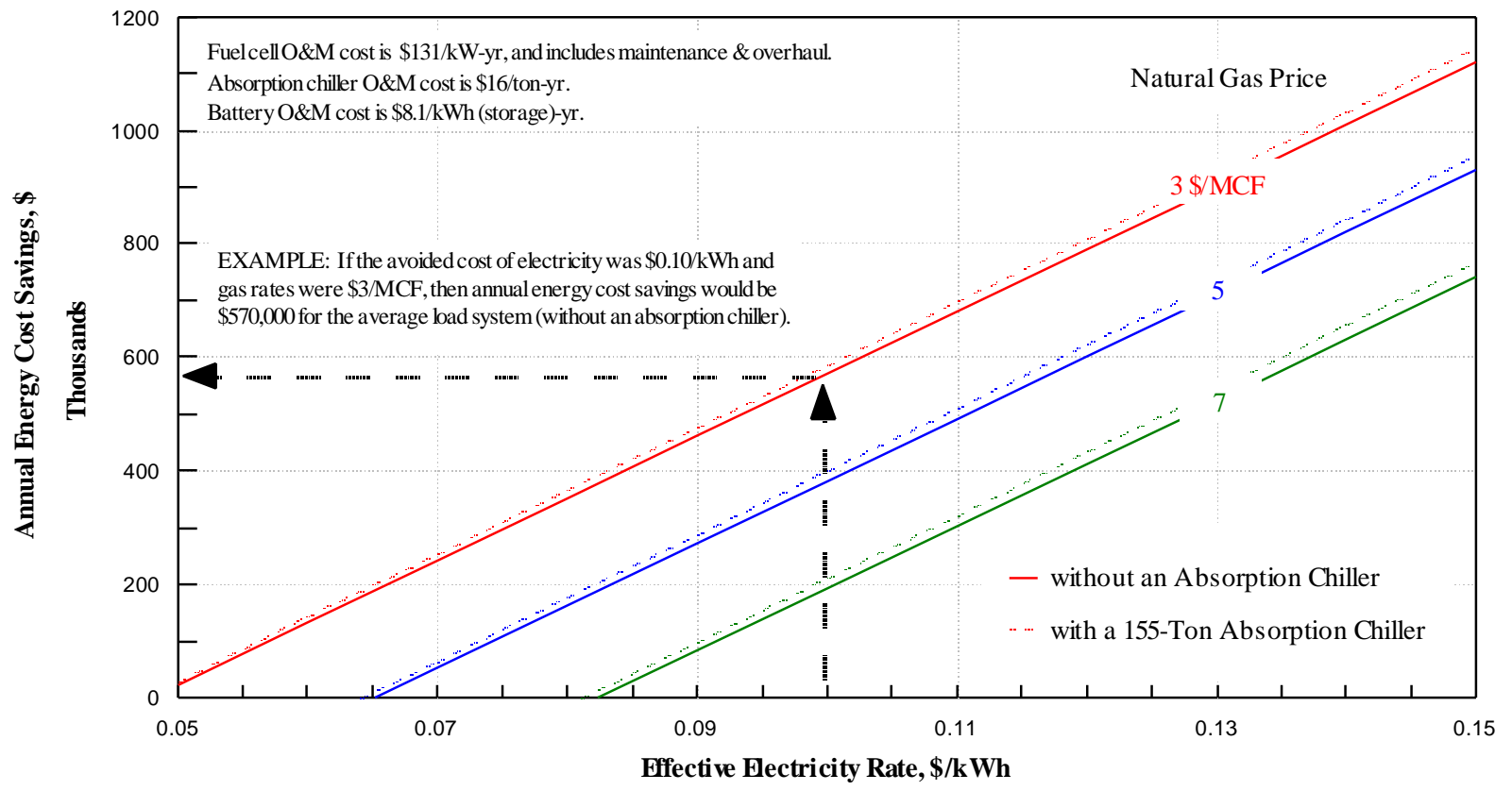

Figure 32b. Annual Energy Cost Savings for the CNG Tower Average Load Systems 


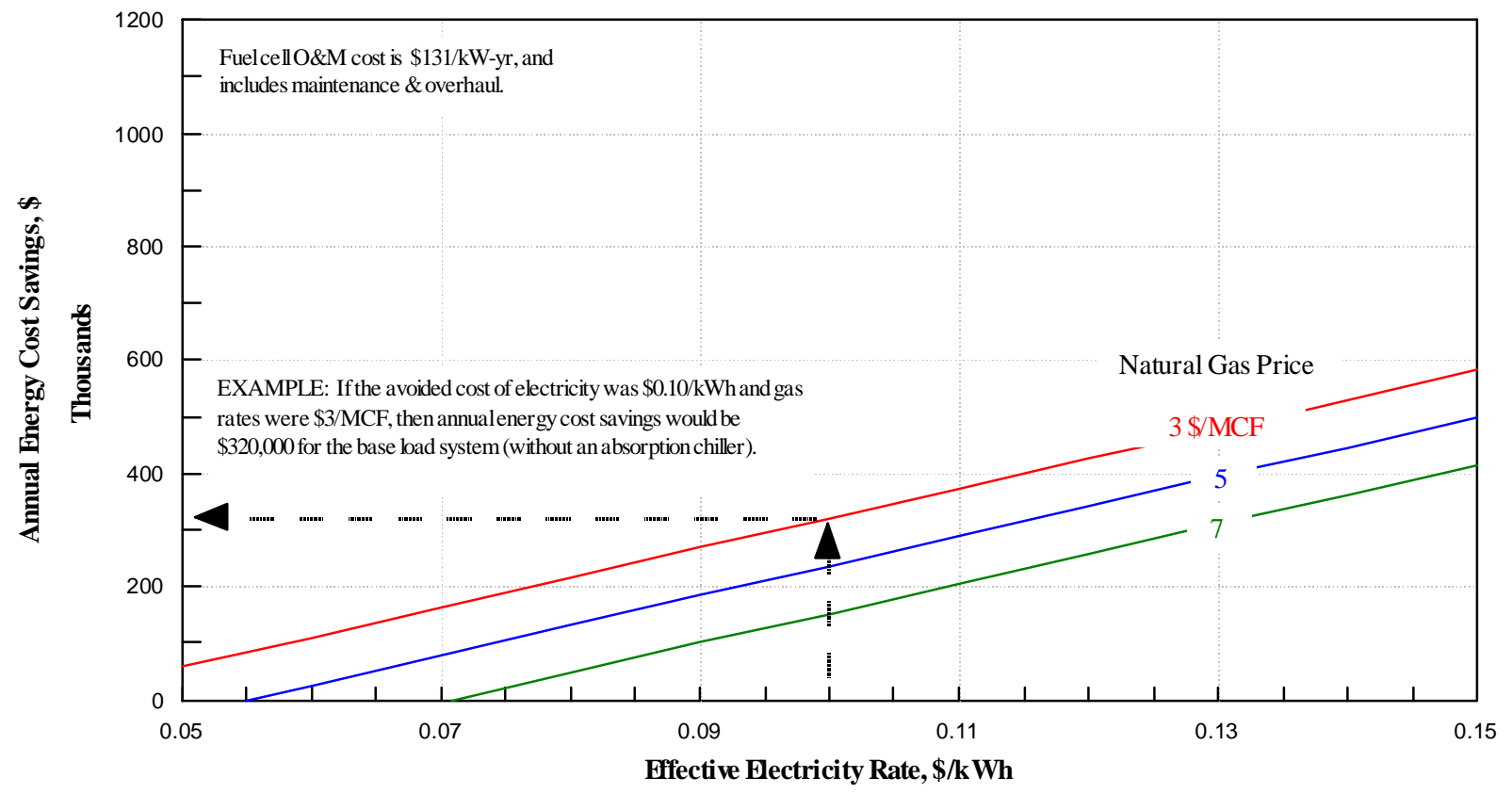

Figure 32c. Annual Energy Cost Savings for the CNG Tower Base Load System

Table 5. 1995 Electric Utility Rate Structure for CNG Tower

\begin{tabular}{||l|l|c|}
\hline \hline \multirow{2}{*}{$\begin{array}{l}\text { Demand } \\
\text { Charge }\end{array}$} & First $300 \mathrm{~kW}, \$ /$ Month & 5,565 \\
\cline { 2 - 3 } & Additional kW, $\$ / \mathrm{kW}$ & 14.08 \\
\hline \hline \multirow{3}{*}{$\begin{array}{l}\text { Energy } \\
\text { Charge }\end{array}$} & Base Rate, $\$ / \mathrm{kWh}$ & 0.0383 \\
\cline { 2 - 3 } & Tariff, $\$ / \mathrm{kWh}$ & 0.002433 \\
\cline { 2 - 3 } & Total, $\$ / \mathrm{kWh}$ & 0.040733 \\
\hline
\end{tabular}

The ordinate of Figures 32a, b, and c, the effective electric rate, includes both demand and energy charges. For example, the CNG Tower's existing system consumed 11,574,000 kWh from the electric utility and registered 12 peak monthly demands which totaled to 28,773. Based on the rates in Table 5, the total annual consumption charge would be:

Consumption Charge $=(0.040733 \$ / \mathrm{kWh})(11,574,000 \mathrm{kWh})=\$ 471,443$.

Recognizing that the CNG Tower's monthly peak was always greater than $300 \mathrm{~kW}$, the total annual demand charge would be:

Demand Charge $=(12)(\$ 5,565)+[28,773-(12)(300)][14.08]=\$ 421,000$. 
The effective electric rate could then be calculated as follows:

Effective Electric Rate $=(\$ 471,443+\$ 421,216) /(11,574,000 \mathrm{kWh})=\$ 0.077 / \mathrm{kWh}$.

While this 1995 rate for the CNG Tower is moderate; many other regions of the country have electricity rates that are much higher. Although the deregulation of the electric utility industry is expected to, in general, lower rates, certain regions which are costly to serve could see their rates increase.

Since fuel cell power is of higher quality than utility power, the effective electricity rate need not necessarily be based solely on the alternative cost of power from the local utility. Some users may be willing to pay more than the local utility rate because they would benefit from the high reliability or high quality of fuel cell power. For example, suppose that one floor of the CNG Tower was rented by a tenant which operated a large, 24-hour computer system that was sensitive to harmonics and voltage fluctuations in its power supply. Such a tenant may be willing to pay as much as $\$ 0.20 / \mathrm{kWh}$ for high-quality fuel cell power if it eliminated costly shutdowns or the cost of an uninterruptible power supply. (A spokesman for a gas utility which installs and operates fuel cells reported receiving as much as $\$ 0.23 / \mathrm{kWh}$ for "premium" fuel cell power in 1996.) If the tenant continuously operated a $250 \mathrm{~kW}$ load, then he would consume 2,190,000 kWh annually. With this information one can recalculate an effective electric rate since part of the fuel cell power is valued more highly than the local utility rate:

$$
\begin{aligned}
\text { Effective Electric Rate }=[(11,574,000 \mathrm{kWh}-2,190,000 \mathrm{kWh})(\$ 0.077 / \mathrm{kWh})+ \\
=(2,190,000 \mathrm{kWh})(\$ 0.20 / \mathrm{kWh})] /(11,574,000 \mathrm{kWh}) \\
=\$ 0.10 / \mathrm{kWh}
\end{aligned}
$$

Making use of this effective electric rate of $\$ 0.10 \mathrm{kWh}$ and an assumed rate for natural gas of $\$ 3 / \mathrm{MCF},{ }^{6}$ Figure 32c shows that the annual energy cost savings for the base load system would then be approximately $\$ 320,000$. Given the same rates, Figures $32 \mathrm{a}$ and $32 \mathrm{~b}$ show that the annual energy cost savings for the peak and average load systems, without absorption chillers, would be $\$ 489,000$ and $\$ 570,000$, respectively.

Economic Feasibility. The economical feasibility of retrofitting the CNG Tower with a fuel cell cogeneration system depends on:

- The annual energy cost savings provided by the system;

- The total capital cost of the equipment, including its installation;

- The assumed life of the system; and

\footnotetext{
${ }^{6}$ In a separate fuel cell cogeneration case study, a gas utility offered a substantial discount for any gas they supplied to the customer's fuel cell by waiving their gas transportation fee. It is assumed that a discount could also be negotiated for the CNG Tower, resulting in a gas price of around \$3/MCF.
} 
- The acceptable financial criteria.

The annual energy cost savings provided by each system are shown in Figures 32a, b, and c as a function of utility rates for electricity and natural gas. These annual operating cost savings must justify the capital equipment and installation costs of the fuel cell power unit, the absorption chiller, and the batteries if a cogeneration system is to be economic. In 1996, absorption chillers in the size range under consideration could be purchased for nominally $\$ 350 /$ ton. The total installed cost for an absorption chiller is conservatively estimated at $\$ 525 /$ ton. Based on an EPRI study (3), the cost of a battery storage system is estimated to be $\$ 190$ per $\mathrm{kWh}$ of storage.

Fuel cell systems are just beginning to be available commercially, and their capital costs are changing rapidly. Therefore, this study did not fix the fuel cell's installed capital cost as a constant. Instead, for each of the fuel cell retrofit systems, the economically feasible fuel cell installed capital costs were calculated as a function of annual energy cost savings under three different financial criteria. See Figures $33 a, b$, and c. If an absorption chiller or battery storage system were included in the retrofit, their installed capital costs were calculated at $\$ 525 /$ ton and $\$ 190 / \mathrm{kWh}$, respectively. All values are in 1996 dollars.

The first financial criterion, a 3-year payback period, is the most demanding. In this scenario, the entire cost of purchasing and installing all the components of the retrofit fuel cell system must be recovered within the first 3 years. The second financial criterion, which requires a 15 percent rate of return over 6 years, is less demanding but still aggressive. In this scenario, the entire cost of purchasing and installing all the components of the retrofit fuel cell system, plus an average annual return of 15 percent, must be obtained in the first 6 years. ${ }^{7}$ Under these first two criteria, the investor would continue to get a return on investment long after the 3-or 6-year financial criteria had been satisfied, assuming that continued operation of the retrofit system would still result in annual energy cost savings. The third and least demanding financial criterion, which requires a 15 percent rate of return over 20 years, emphasizes the value of the retrofit fuel cell system over its entire life. In this scenario, the entire cost of purchasing and installing all the components of the retrofit fuel cell system, plus an average annual return of 15 percent, must be obtained over the system's 20-year life. Of these three financial criteria, the second is perhaps the best representative of the financial requirements that fuel cell projects are presently encountering.

Using Figure 32c, an example in the previous section showed that the annual energy cost savings for the base load system would be approximately $\$ 320,000$ given an effective electric rate of $\$ 0.10 / \mathrm{kWh}$ and a natural gas rate of $\$ 3 / \mathrm{MCF}$. Given these energy savings of $\$ 320,000 /$ year, Figure 33c shows that an installed fuel cell capital cost equal to or less than $\$ 2020 / \mathrm{kW}$ is required for economic feasibility under the financial criterion which requires a 15 percent rate of return over 6 years. Assuming the same electric and gas rates, and given the same financial criterion, Figures $33 \mathrm{a}$ and $33 \mathrm{~b}$ show that installed fuel cell capital costs less than or equal to $\$ 660 / \mathrm{kW}$ and $\$ 750 / \mathrm{kW}$ are required for economic feasibility of the peak and average load systems, respectively.

${ }^{7}$ That is, the net present value of energy cost savings for the first 6 years, discounted at 15 percent, equals the total installed capital cost of the fuel cell retrofit system. 


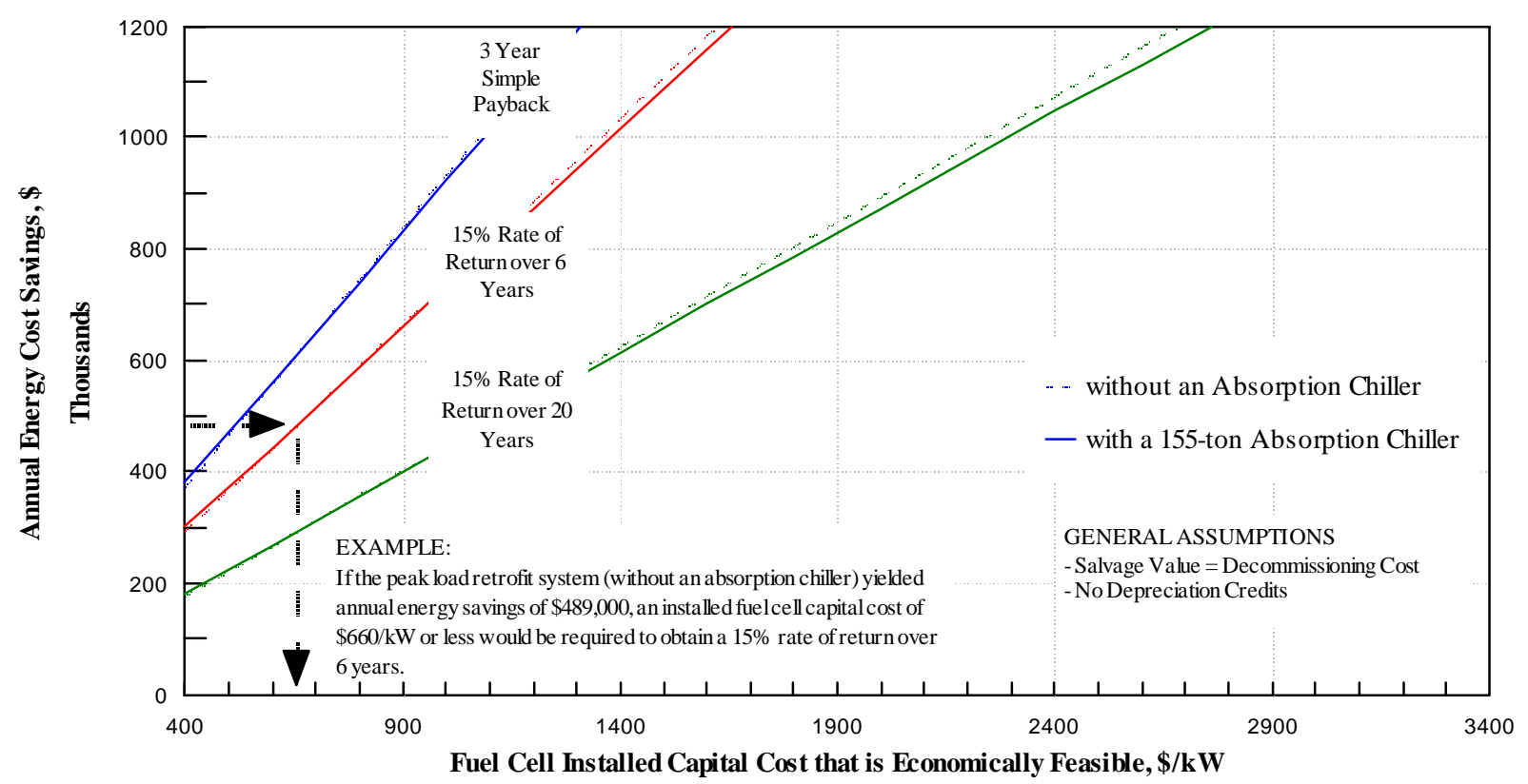

Figure 33a. Conditions for Economic Feasibility of the Peak Load Fuel Cell Retrofit Systems

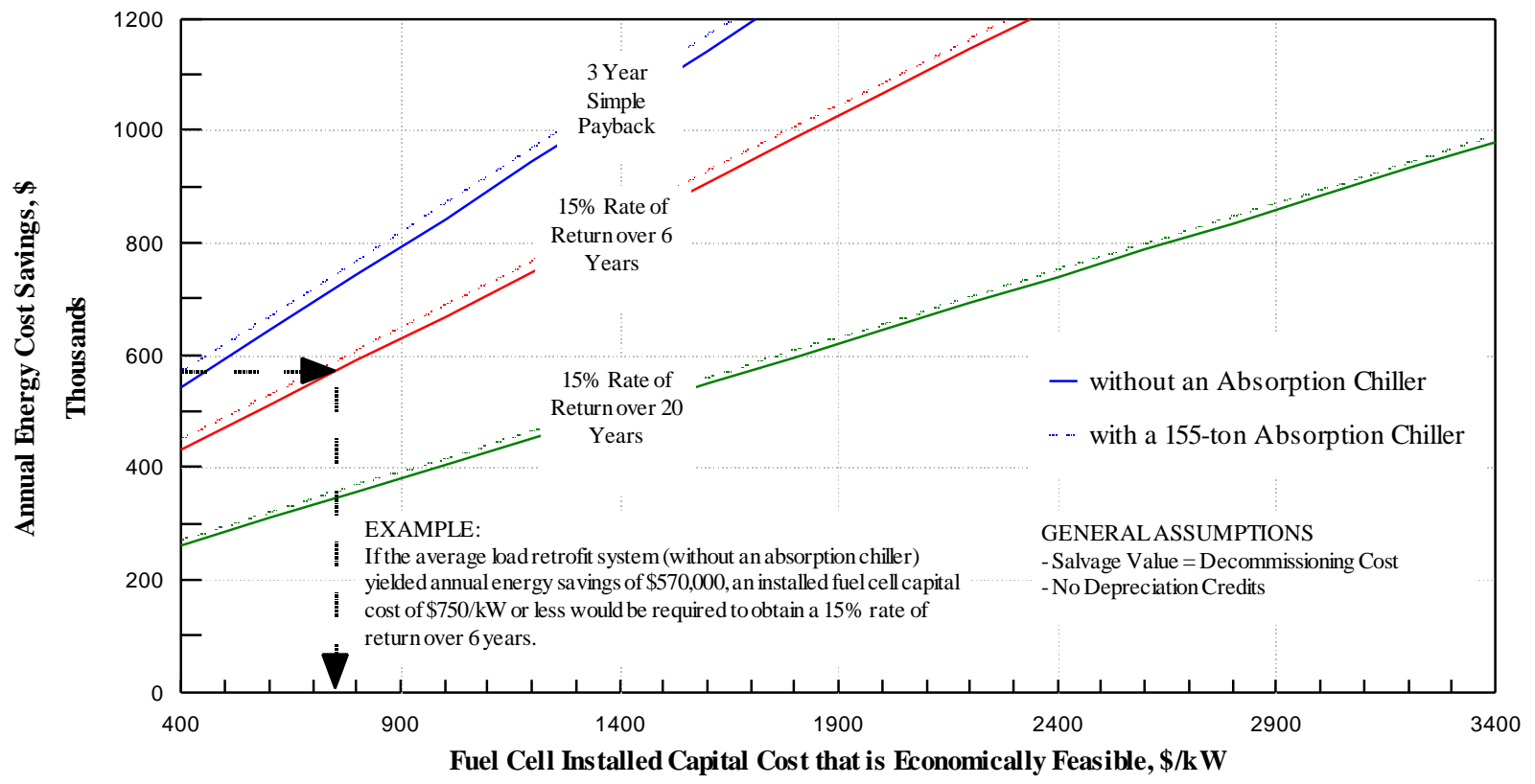

Figure 33b. Conditions for Economic Feasibility of the Average Load Fuel Cell Retrofit Systems 


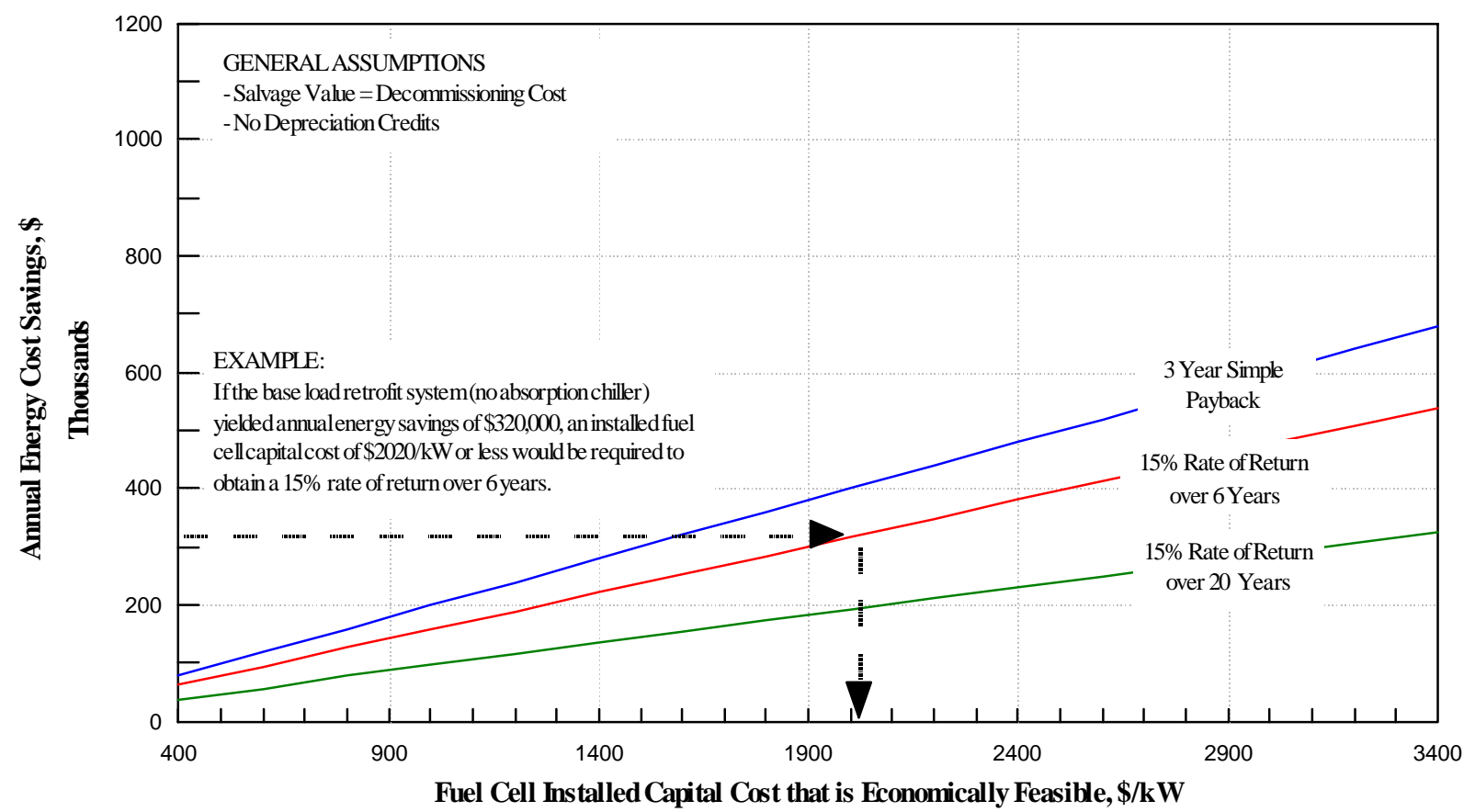

Figure 33c. Conditions for Economic Feasibility of the
Base Load Fuel Cell Retrofit System

In 1996, the uninstalled capital cost of a commercially available, $200 \mathrm{~kW}$ phosphoric acid fuel cell system was $\$ 3,000 / \mathrm{kW}$. However, since the CNG Tower's cooling tower is of sufficient capacity to reject the fuel cell's waste heat, the $\$ 3,000 / \mathrm{kW}$ commercial cost would be reduced by the cost of the system's heat rejection unit. Furthermore, the retrofit systems considered in this study are 3 to 14 times larger than the $200 \mathrm{~kW}$ system for which the $\$ 3,000 / \mathrm{kW}$ price applies. Economies of scale, especially in the balance of plant, would reduce the $\$ / \mathrm{kW}$ cost for the systems considered here. In addition, as phosphoric acid fuel cell market share grows and manufacturing capacity increases, their costs are expected to decline, eventually reaching an uninstalled capital cost of $\$ 1,200$ to $\$ 1,500 / \mathrm{kW} .{ }^{8}$ Although installation costs are highly site specific, the Morgantown office of the Federal Energy Technology Center conducted a study in 1996 which determined that the installation cost of a $200 \mathrm{~kW}$ phosphoric acid fuel cell would be between 20 and 30 percent of its uninstalled cost. Given this information, it appears that an "allowable" 2020/kW fuel cell cost, calculated in the above example for the base load CNG Tower retrofit, could be realized in the near term.

${ }^{8}$ Capital costs should be driven down further as other types of fuel cells which are suitable for cogeneration become commercially available in the next few years. These higher temperature fuel cells include solid oxide and molten carbonate, which operate at $1,800{ }^{\circ} \mathrm{F}\left(1,000{ }^{\circ} \mathrm{C}\right)$ and $1,200{ }^{\circ} \mathrm{F}\left(1,000{ }^{\circ} \mathrm{C}\right)$, respectively. 
When the installed fuel cell capital cost does eventually decrease to $\$ 1500 / \mathrm{kW}$, what utility rates would justify installing a retrofit fuel cell cogeneration system in the CNG Tower? Figure 33c shows that an installed fuel cell capital cost of $\$ 1500 / \mathrm{kW}$ would require $\$ 230,000$ in annual energy cost savings to achieve a 15 percent return on investment over 6 years. Figure 32c shows the combinations of natural gas prices and effective electric rates that would generate the required level of annual energy cost savings. For example, the following rate combinations would make the base load fuel cell retrofit economically feasible: $\$ 3 / \mathrm{MCF}$ and $\$ 0.082 / \mathrm{kWh}$, or $\$ 5 / \mathrm{MCF}$ and $\$ 0.10 / \mathrm{kWh}$.

In addition to meeting the specified financial criterion, a fuel cell cogeneration system must also be more economically attractive than other cogeneration retrofit options based on strong competitors such as reciprocating engines and turbines.

Incremental Benefit of Absorption Chillers. Is the benefit of adding an absorption chiller worth its cost? Figures $34 \mathrm{a}$ and $34 \mathrm{~b}$ can be used to determine if equipping a fuel cell system with an absorption chiller is economically feasible. These figures show the incremental increase in annual energy cost savings from adding an absorption chiller to the peak load and average load fuel cell retrofit systems, respectively. Based on an installed capital cost of $\$ 525 /$ ton, the absorption chiller must increase the annual energy cost savings by $\$ 139 /$ ton to realize a 15 percent rate of return over 6 years. In Figures 34a and 34b, a horizontal line has been drawn to illustrate this "economic threshold" of $\$ 139 /$ ton. The portion of the curve which lies above the economic threshold line are economically feasible; those below are economically infeasible.

Absorption chillers of two sizes, 120 and 205 tons, were considered for the peak load system, as illustrated in Figure 34a. These absorption chillers become more economically attractive as the natural gas price rises. The absorption chiller reduces the amount of electricity required for air conditioning and consequently the amount of natural gas which must be burned by the peak load fuel cell. Therefore, the higher the natural gas price, the larger the energy cost savings afforded by the absorption chiller. (Unfortunately, as the natural gas price rises, the overall fuel cell retrofit project becomes less attractive economically.) Figure 34a shows that the peak load system's 120-ton absorption chiller is economically feasible (15 percent rate of return over 6 years) when the natural gas price is equal to or greater than 5.9 \$/MCF. Figure 34a shows that the 205-ton absorption chiller is not economically feasible for any reasonable natural gas price. Therefore, if natural gas prices rose above 5.90 \$/MCF, the peak load system would be equipped with a 120-ton absorption chiller.

Absorption chillers of two sizes, 120 and 155 tons, were considered for the average load system, as illustrated in Figure 34b. These absorption chillers become more economically attractive as the effective electric rate rises. The absorption chiller reduces the amount of electricity required for air conditioning and consequently the cost of purchasing power from the 


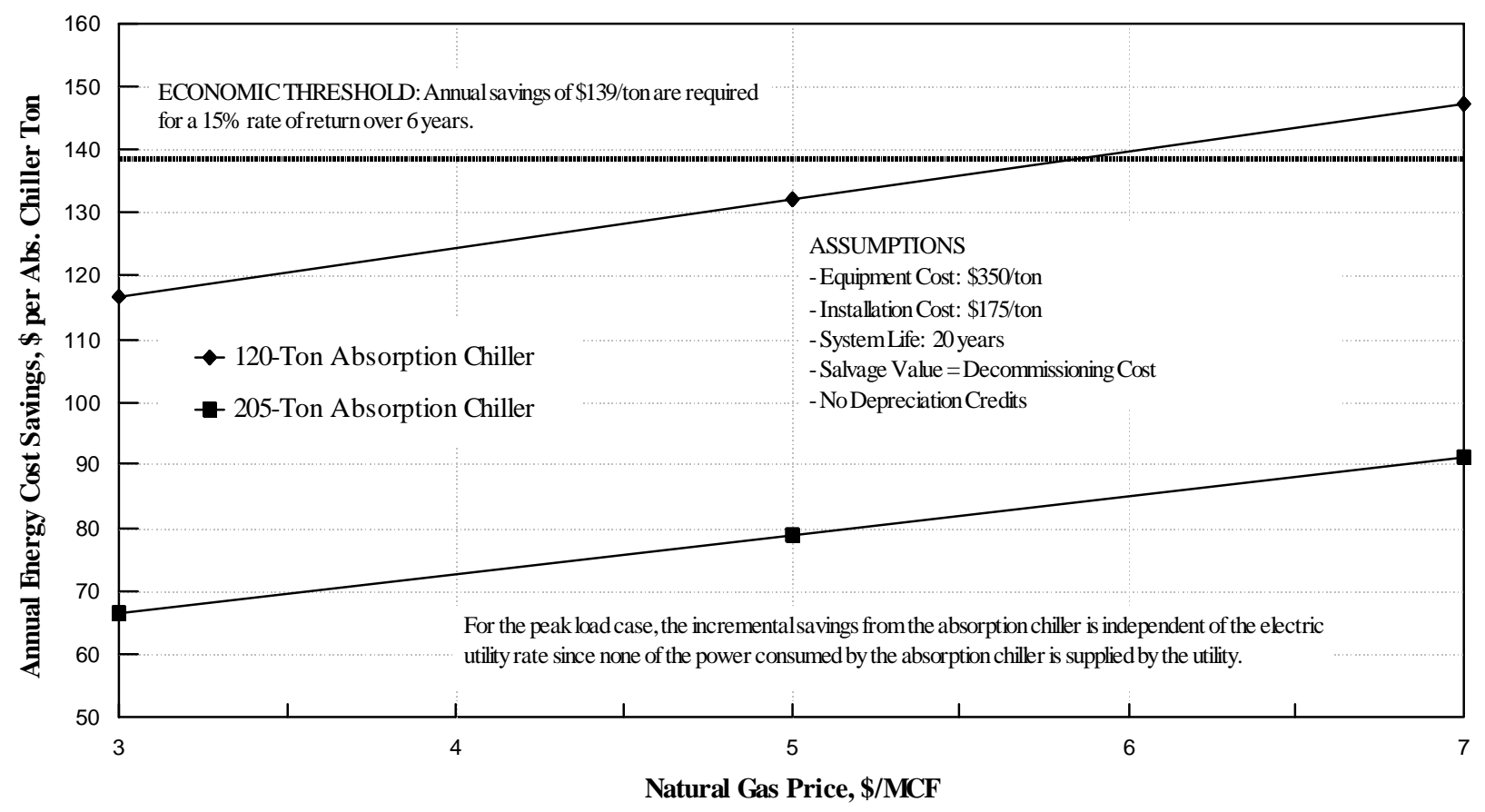

Figure 34a. Annual Energy Cost Savings from Absorption Chillers Peak Load System

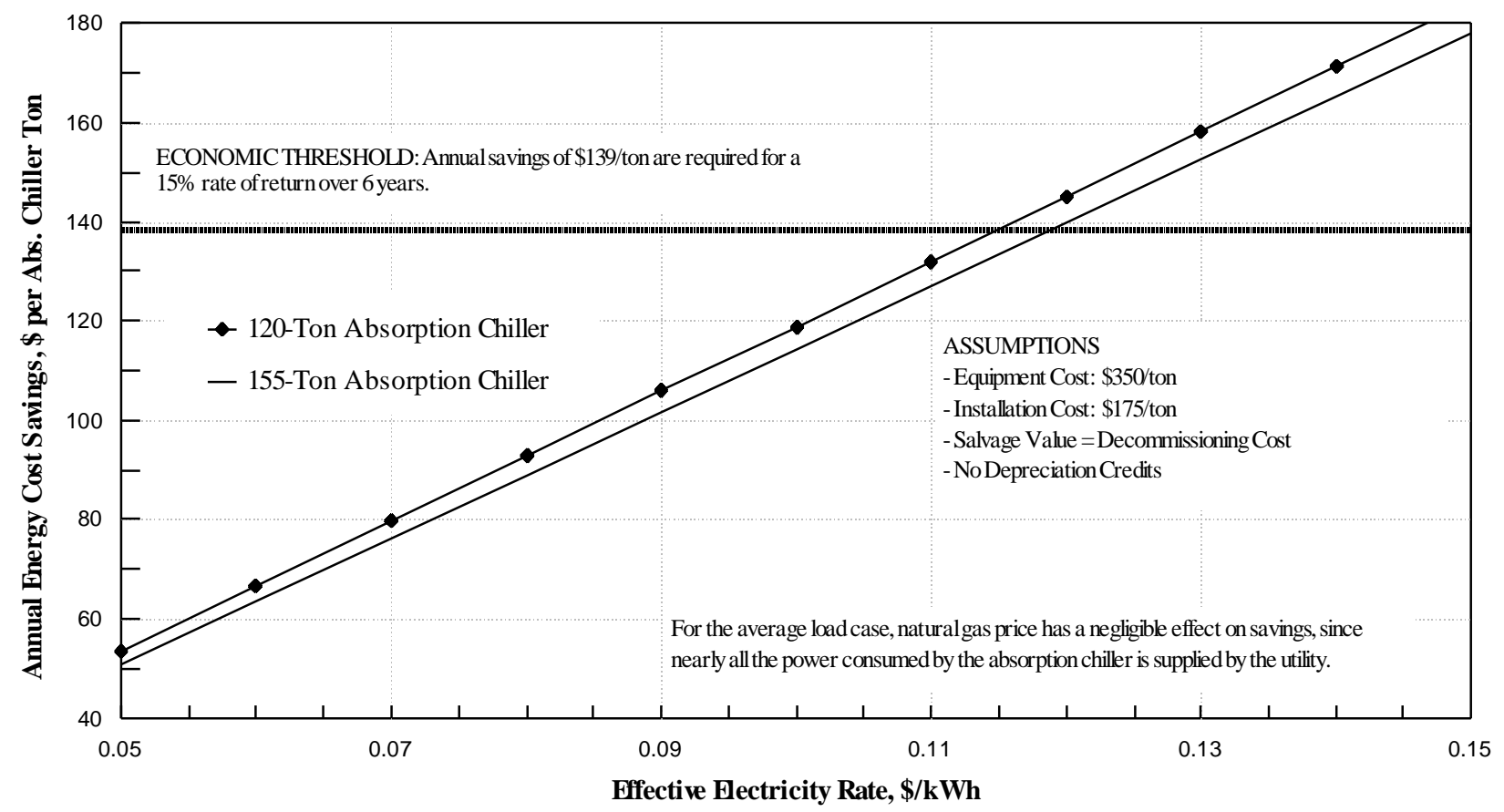

Figure 34b. Annual Energy Cost Savings from Absorption Chillers Average Load System 
local utility. Therefore, the higher the effective electric rate, the larger the energy cost savings afforded by the absorption chiller. Figure 34b shows that both the 120-ton and 155-ton absorption chillers are economically feasible ( 15 percent rate of return over 6 years) for the average load system when the effective electric rate is equal to or greater than $\$ 0.12 / \mathrm{kWh}$. For example, given an effective electricity rate of $\$ 0.13 / \mathrm{kWh}$, then the absorption chillers would contribute the following amounts to the annual energy cost savings of the average load retrofit:

Annual Savings from Average Load System's 120-Ton Absorption Chiller $=(\$ 158 /$ Ton $)(120$ Tons $)=\$ 18,960$

Annual Savings from Average Load System's 155-Ton Absorption Chiller $=(\$ 152 /$ Ton $)(155$ Tons $)=\$ 23,560$

Although the smaller chiller would generate a slightly higher percentage return on investment, the larger, 155-ton chiller was selected for the average load system since it maximizes the amount of annual energy cost savings. The 155-ton chiller would be included when the effective electric rate exceeded $\$ 0.12 / \mathrm{kWh}$.

Energy Conservation. From an energy security point of view, the fuel cell retrofit systems would help our Nation conserve its fossil fuel resources. The fuel cell retrofit systems consume less primary energy than the CNG Tower's existing system for two reasons: (1) the fuel cell converts primary energy to electricity more efficiently than does the utility, and (2) the fuel cell system, by utilizing reject heat, reduces the consumption of both natural gas for space heating and, if an absorption chiller is used, electricity for air conditioning. Table 4 contains a detailed breakdown of each system's primary energy consumption, assuming that the local electric utility operates at an overall efficiency of 32 percent based on the LHV of the fuel. The peak, average, and base retrofit systems without absorption chillers consume 21, 20, and 12 percent less primary energy than does the existing system. With absorption chilling, primary energy consumption is reduced by 22 percent for both the peak and average load systems as indicated in Figure 35.

\footnotetext{
${ }^{9}$ On any weekday which requires air conditioning, the average load system must purchase power from the electric utility. Therefore, on the margin, any decrease in electricity consumption for weekday air conditioning reduces the amount of electricity purchased from the utility, and the increase in annual energy savings is dependent solely upon the effective electricity rate. On weekends, the majority, if not all, the electricity required for air conditioning is provided by the fuel cell. Therefore, on the margin, any decrease in electricity consumption for weekend air conditioning reduces the amount of power the fuel cell must generate, and the increase in annual energy savings is dependent solely upon the natural gas price. However, since the weekday effect of absorption chillers greatly dominates the weekend effect, the overall increase in annual energy savings is essentially dependent only on the effective electric rate.
} 


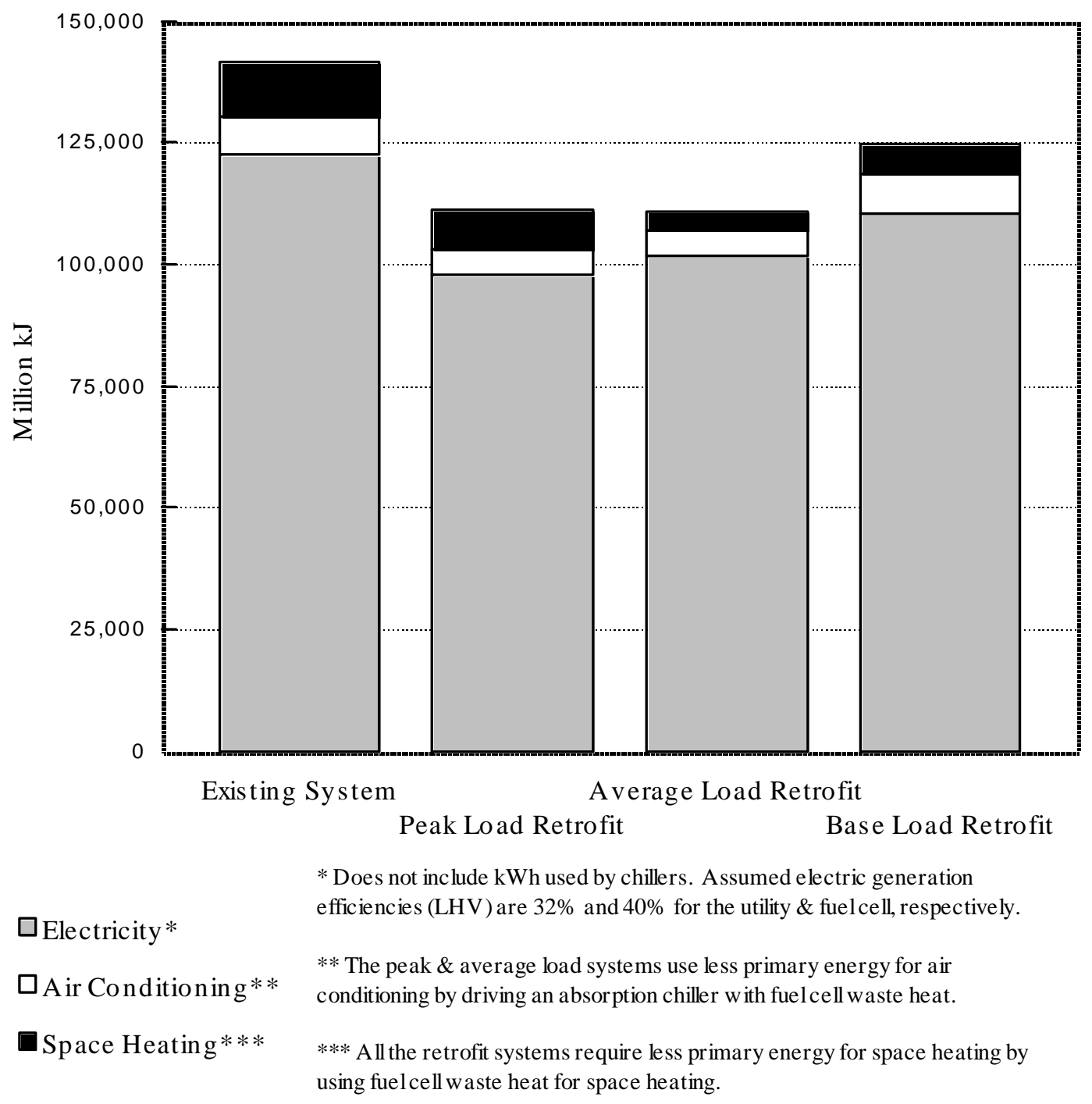

Figure 35. Primary Energy Use by the Existing and Retrofit Systems 


\section{Conclusions}

A preliminary system design and economic evaluation has been carried out for five fuel-cellbased cogeneration arrangements retrofitted to an existing 32-story office building. The arrangements are all based on an ONSI PC25C phosphoric acid fuel cell generation unit adapted to the specific power, heat, and air conditioning requirements of the CNG Tower in downtown Pittsburgh, PA. These cogeneration systems differ in their power generation capacity -- the peak, average, or base load demand of the building -- and in the extent to which their reject heat is used in an absorption chiller to provide air conditioning.

This work has established a generalized system design and performance evaluation procedure for a building cogeneration system, outlined in Appendix $\mathrm{C}$ of this report. The work has also provided insight on technical and economic aspects of fuel-cell-based systems for cogeneration in large office buildings. These are the general conclusions of the work.

- Fuel-cell-based cogeneration systems can reduce by 20 percent or more the annual primary energy consumption of large office buildings which presently purchase their electric power from a local utility.

- A PAFC-based cogeneration system for a large office building may well be technically and economically feasible, dependent on local electricity and gas rates and on the system's capital and maintenance cost details. In addition, other factors may enhance the success of such a cogeneration system in the commercial building energy supply market: the need for a premium, reliable power; local environmental restrictions on $\mathrm{NO}_{\mathrm{X}}$ and $\mathrm{SO}_{2}$ emissions; power transmission and distribution costs in an urban setting; and a local utility's reserve margins. PAFC power units have demonstrated the ability to generate premium power at high availability -- attractive features for computer and other sensitive applications. These units have also demonstrated unsurpassed environmental performance -- low $\mathrm{NO}_{\mathrm{X}}$ and $\mathrm{SO}_{2}$ emissions. Since fuel cell units themselves have no moving parts, noise and vibrations are low. Fuel cell units can, therefore, be located within a building, minimizing the problems of urban power plant siting and transmission and distribution line location.

- In several respects, however, the $200 \mathrm{~kW}$ ONSI PC25C fuel cell power unit is not ideally suited to cogeneration in a large office building.

- The power demands of the CNG Tower application are 3 to 14 times that of the commercially available unit. Fuel cell stacks are modular, and may economically meet the demand simply by adjusting the number of stacks. But other components of the power unit -- in particular, the natural gas fuel processing and the heat rejection and recovery equipment are not inherently modular, and are most economic when scaled in capacity to meet the power and heat demands on the unit.

- Not all of the reject heat from the ONSI unit is available at a temperature which allows its effective use in the conventional water-based, hydronic, heating system or in an absorption-chiller-based air conditioning system for the building. Operating at full 
power, only half of the reject heat from the unit can be used in building heating or cooling; at half load or less, none of the reject heat is available at a temperature which allows such use. Higher temperature reject heat from the fuel cell power unit would also significantly increase the coefficient of performance of the absorption chiller.

- In order to achieve effective system operation, maximum energy efficiency, and minimum total cost for the cogeneration and building HVAC equipment, heat rejection and recovery equipment for the fuel cell power generation unit should be integrated with the building equipment for:

- Heating, ventilation, and air conditioning (heat and moisture removal),

- Heat rejection in the cooling tower, and

- Power and climate control.

- Obviously, the peak-load fuel-cell cogeneration system had the highest capital cost and lowest capacity factor of the systems considered. Such a system also had the distinct disadvantage that when it operated at less than half the peak load, none of the reject heat was at a temperature suited to building heating or cooling.

- The average-load fuel-cell cogeneration system, which included battery electrical energy storage, provided advantages. If the fuel cell capacity, $\mathrm{kW}$, were equal to the average weekday demand and if the battery storage capacity, $\mathrm{kWh}$, were sufficient, the system could provide all the power requirements of the building, including the peak loads, throughout the week. (In this study, however, the fuel cell and the battery storage capacities were sized to meet only the non-air conditioning, not the maximum air conditioning, demand. Power from the utility was to be used very occasionally during the hottest weekday hours to provide for the air conditioning.) Batteries can be charged at night when the demands are low, and discharged during the day when demands are high. The capital cost of the average-load system is minimized while its capacity factor is maximized. The estimated cost of the battery storage capacity required is currently less than that of the fuel cell capacity it replaces. In addition, the fuel cell unit operates at a constant, design-power load during the weekdays, minimizing operating problems and maximizing the amount of useful heat available for building heating and cooling. Emergency power can also be provided by excess battery capacity.

- Again obviously, the base-load fuel-cell cogeneration system had the lowest capital cost and the highest capacity factor of the systems considered. This system operates continually at its design load. Such operation maximizes the fraction of its reject heat suitable for heating (or perhaps air conditioning) the building.

- Retrofit installations of a fuel cell cogeneration system have the advantage of using equipment from the current building heating and cooling systems as auxiliary or backup systems. But retrofit installations do not realize the full operational and economic benefit of integrating a building's cogeneration system with its HVAC and hot water supply systems. 
Such integration will require significant engineering effort. But this requirement is counter to the present tendency of fuel cell system developers and manufacturers to reduce capital costs of their power generation units by standardizing the designs.

Further work is needed to determine the conditions under which PAFC power units might be the system of choice for cogeneration in large office buildings, as well as other commercial installations. 


\section{Recommendations}

It is appropriate to consider and evaluate cogeneration systems at this time of rapid change in the electric utility industry. Power generation is being deregulated; competition is being introduced to generation while power transmission and distribution remain a governmental regulated monopoly of local utilities. This technical and economic study of a fuel-cell-based cogeneration system retrofit to a specific urban office building should be broadened and extended to explore the potential benefits of such systems and to guide their technical and commercial development.

- The performance in cogeneration of additional fuel cell types should be evaluated -molten carbonate and solid oxide cells, which operate and provide reject heat at higher temperatures -- perhaps in the range of $1000{ }^{\circ} \mathrm{F}$ to $1800{ }^{\circ} \mathrm{F}$. Preliminary estimates indicate that all the CNG Tower's heat and air conditioning requirements might be met by the use of reject heat from a fuel cell system designed for the peak load, provided that the heat were available at a temperature of $250{ }^{\circ} \mathrm{F}$ or higher. Further analysis of this possibility is required. And additional applications should be considered -- hospitals, hotels, and shopping centers. Cogeneration systems based on fuel cells for power generation should also be compared with those based on engines and turbines, gas and steam.

- Further detailed consideration should be given to the scale up and adaptation of fuel cell systems to cogeneration. The CNG Tower application requires a generation capacity 3 to 14 times that of the ONSI fuel cell system, currently the only commercially available fuel cell system. While fuel cell stacks are modular and their capital cost per $\mathrm{kW}$ is independent of the capacity of the system, other components of the system are not modular -- the natural gas fuel processor; the fuel cell housing, insulation, and interconnecting piping; the reject heat removal and recovery equipment; the power conditioning hardware; and the instrumentation, control, and operating hardware. And the cost of these components is estimated to be as much as 2/3's of the overall cogeneration system costs. Appropriate scaling of these components to an application is required. The capital cost of the cogeneration system per $\mathrm{kW}$ of capacity of the resulting system is expected to decrease as its capacity increases.

- Detailed study should also be given to the adaptation of the fuel cell cogeneration system to the heating and air conditioning systems of the building or to other applications. Various means should be considered for:

- Cooling the fuel cell -- including the choice of coolant and its temperature, pressure, and rate of circulation.

- Processing the natural gas fuel and preheating the air.

- Recovering heat from the effluent fuel and air streams from the fuel cell.

The effects of these various means on the cogeneration system performance and economics of specific building applications should then be studied. 
- Storage systems for electrical energy, heat, and "cold" should be given further consideration, particularly as a means for dealing with daily power, heating, and air conditioning load profiles and their variability. The current study dealt only with electrical energy storage. The integration of the power conditioning and control aspects of electrical energy storage will also require additional study.

- Alternative, novel building heating and air conditioning system designs should be considered for cogeneration systems in new buildings. These systems might be based on various fluids -water, steam, or special heat transfer fluids. The air conditioning system might include sorbent based dehumidification and contaminant removal as well as air cooling.

The purpose of all these recommendations is to discover opportunities for the commercialization of fuel cell technology by identifying economic benefits of various cogeneration applications. 


\section{References}

Arthur D. Little. Fuel Cells for Building Applications: Market Analysis, Technology Status and Program Plan Overview. Reference \#42526. 1994.

Lawrence Berkeley Laboratory. 481 Prototypical Commercial Buildings for Twenty Urban Market Areas. Gas Research Institute. GRI-90/0326. LBL-29798. 1990.

Bechtel Group, Inc. Design and Costs for a Generic 10-MW Utility Lead-Acid Energy Storage Plant. EPRI \#RP2123-6. 1988. 


\section{Appendix A. Analysis of Heating-Cooling Versus Outside Air Temperature Curves}

The HVAC system for a given floor in the CNG Tower as shown in Figure A-1 is simply represented as two well-mixed regions of conditioned, heated or cooled, air --

- The peripheral or exterior region of the floor adjacent to the windows and exterior wall of the building. Heat is added to this region at a rate $\mathrm{Qh}, \mathrm{Btu} / \mathrm{h}$, by fan coil units located above the false ceiling over the windows. Heat is exchanged between this exterior region and the building surroundings at a rate $\mathrm{UA}^{*}(\mathrm{Tbo}-\mathrm{T}), \mathrm{Btu} / \mathrm{h}$,

where $\quad \mathrm{U}=$ the overall heat transfer coefficient, $\mathrm{Btu} / \mathrm{h} \mathrm{ft}{ }^{2} \mathrm{~F}$

$\mathrm{A}=$ the effective area for heat exchange, $\mathrm{ft}^{2}$

Tbo $=$ the air temperature in the exterior region of the Tower, $\mathrm{F}$

$\mathrm{T}=$ the temperature of the surroundings of the Tower, the outside air (oa) in ${ }^{\circ} \mathrm{F}$

- The interior region of the floor including also the plenum room, air circulation fan, cooling coils for air cooling, and ports for the exhaust of building air and the admission of fresh air. Heat is removed from the air in this region by the cooling coils at a rate Qac, Btu/h; but also heat is generated and added to the region at a rate, Qgen, due to activity in the building, people, and the use of power. The rate at which fresh air is drawn in and exhaust air expelled is $\mathrm{m}, \mathrm{lb} / \mathrm{h}$; the resultant exchange of heat with the building surroundings is $\mathrm{m}^{*} \mathrm{Cp} *(\mathrm{~T}-\mathrm{Tbi})$, $\mathrm{Btu} / \mathrm{h}$,

where $\mathrm{Cp}=$ the specific heat of the air, Btu/lb F

$\mathrm{Tbi}=$ the air temperature in the interior region of the Tower in ${ }^{\circ} \mathrm{F}$

The interior region also exchanges heat with the exterior region of a floor in the Tower due to air circulation between the regions of $\mathrm{R}^{*} \mathrm{~m}, \mathrm{lb} / \mathrm{h}$. This quantity of heat is $\mathrm{R}^{*} \mathrm{~m} * \mathrm{Cp} *(\mathrm{Tbi}$ Tbo), Btu/h.

Steady-state heat balances can now be written for both regions of a floor in the CNG Tower. For the exterior region,

$$
\mathrm{Qh}=\mathrm{R}^{*} \mathrm{~m} * \mathrm{Cp} *(\mathrm{Tbo}-\mathrm{Tbi})+\mathrm{UA}^{*}(\mathrm{Tbo}-\mathrm{T}) .
$$

And for the interior region,

$$
-\mathrm{Qac}+\mathrm{Qgen}=\mathrm{m} * \mathrm{Cp} *(\mathrm{Tbi}-\mathrm{T})+\mathrm{R} * \mathrm{~m} * \mathrm{Cp} *(\mathrm{Tbi}-\mathrm{Tbo})
$$

The sum of these two independent equations provides the overall heat balance for the floor.

$$
-\mathrm{Qac}+\mathrm{Qgen}+\mathrm{Qh}=\mathrm{m}^{*} \mathrm{Cp} *(\mathrm{Tbi}-\mathrm{T})+\mathrm{UA} *(\mathrm{Tbo}-\mathrm{T}) .
$$




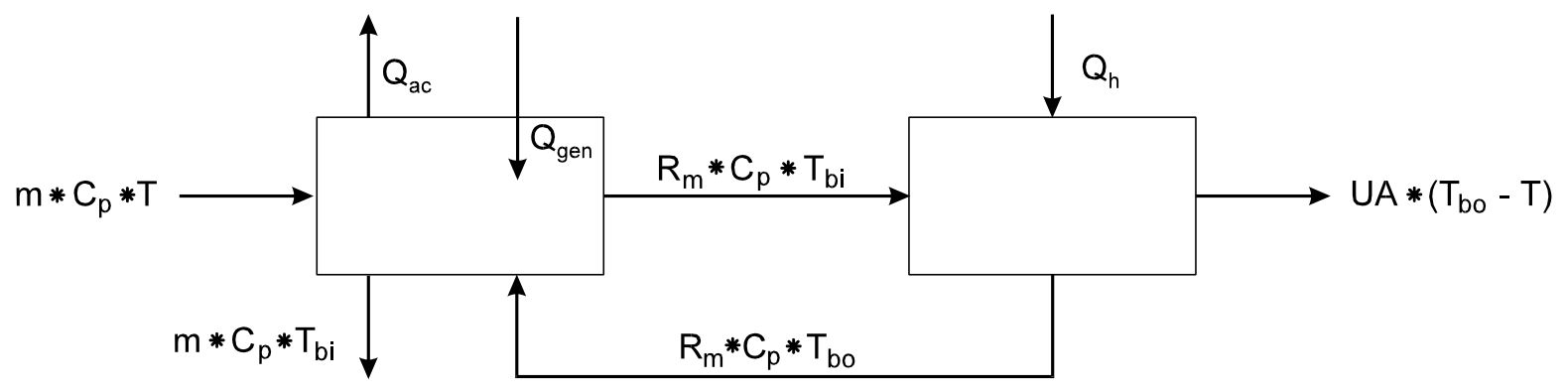

Figure A-1. Heat Balance Representation of the HVAC Arrangements for a Floor of the CNG Tower

These equations -- linear in the temperature, $\mathrm{T}$, of the air surrounding the Tower -- can be used to construct and interpret Q-T plots similar to that of Figure 19. It is assumed in doing this that Qgen is fixed by activity in the building; that $\mathrm{m}$ and $\mathrm{R} * \mathrm{~m}$ (or R) are set by the operating conditions of the ventilation system; and that UA is established by the design of the building -- its window and wall structure. The value of the temperature in the region of the floor adjacent to the windows, Tbo, is assumed to be established by those important people occupying this area. Four independent variables remain in the two independent equations -- $\mathrm{Qh}$, Qac, Tbi, and the outside temperature, $\mathrm{T}$.

Various assumptions can be adopted and Q-T curves plotted for both Qh and Qac. In the winter season, $\mathrm{T}<\mathrm{Tbo}$ and $\mathrm{Qac}=0$; and the equations give the following $\mathrm{Qh}-\mathrm{T}$ relation

$$
\mathrm{Qh}=\{[\mathrm{R} * \mathrm{~m} * \mathrm{Cp} /(1+\mathrm{R})]+\mathrm{UA}\} *(\mathrm{Tbo}-\mathrm{T})-[\mathrm{R} /(1+\mathrm{R})] * \mathrm{Qgen} .
$$

But in the summer season, $\mathrm{T}>\mathrm{Tbo}$ and $\mathrm{Qh}=0$; and the equations give the following Qac-T relation

$$
\text { Qac }=\text { Qgen }-[(1+\mathrm{R}) * \mathrm{UA} / \mathrm{R}+\mathrm{mCp}]^{*}(\mathrm{Tbo}-\mathrm{T}) .
$$

These two linear equations are plotted in Figure A-2. The plot of the experimental data from the CNG Tower summarized in Figure 19 can be interpreted by comparison with Figure A-2. The overall air circulation rate in the building, $\mathrm{R}^{*} \mathrm{~m}$, is approximately $565^{*} 10^{3} \mathrm{sft}^{3} / \mathrm{m}, 2.73 \mathrm{lb} / \mathrm{h}$. The value of $R$, required to provide 15 percent fresh air in the building, is in the range 6 to 7 . The value of $\mathrm{Cp}$ for air is $0.24 \mathrm{Btu} / \mathrm{lb} \mathrm{F}$.

In spring and fall seasons, T Tbo, both air conditioning and heating may operate simultaneously and both Tbo and Tbi can be adjusted therefore to an ideal value, Tb. In this instance,

$$
\mathrm{Qh}=\mathrm{UA} *(\mathrm{~Tb}-\mathrm{T})
$$




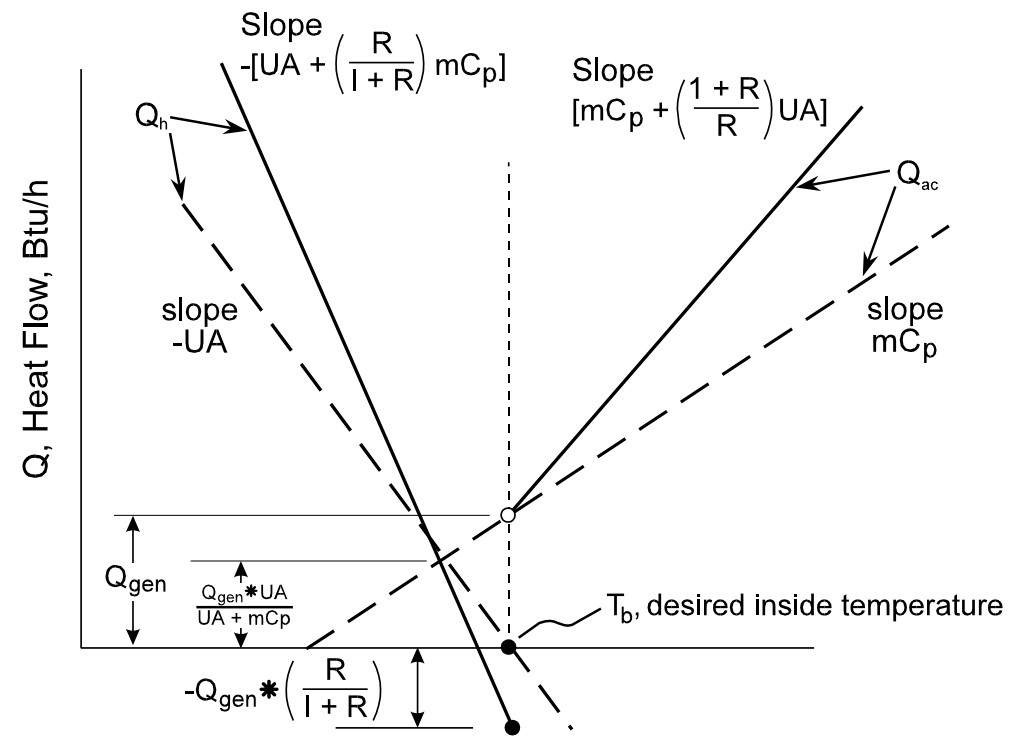

$\mathrm{T}$, Outside Temperature, ${ }^{\circ} \mathrm{F}$

Heating only in winter, air conditioning only in summer, to maintain $\mathrm{Tbo}=\mathrm{Tb}$

$-\ldots-$ Simultaneous heating and cooling to maintain $\mathrm{Tbi}=\mathrm{Tbo}=\mathrm{Tb}$

Figure A-2. CNG Tower Heating - Cooling Curve Analysis

$$
\text { Qac }=\text { Qgen }-\mathrm{m} * \mathrm{Cp} *(\mathrm{~Tb}-\mathrm{T}) \text {. }
$$

These heating and cooling lines are also plotted as dashed lines in Figure A-2; they cross at

$$
\begin{aligned}
& \mathrm{Qh}=\mathrm{Qac}=\mathrm{UA} *[\mathrm{Qgen} /(\mathrm{mCp}+\mathrm{UA})] \\
& \mathrm{T}=\mathrm{Tb}-[\mathrm{Qgen} /(\mathrm{mCp}+\mathrm{UA})]
\end{aligned}
$$

Further consideration of this analysis is required to interpret the data obtained from the CNG Tower. 


\section{Appendix B. Speculation Concerning ONSI Fuel Cell System Arrangements For Heat Management}

Technical data provided on an earlier model $200 \mathrm{~kW}$ ONSI fuel cell power unit provides a plot from which to calculate the quantity of heat available from the system dependent on the supply and return temperature of a heat transfer media, Figure 24. But a similar plot is not available for the more recent ONSI PC25C model, and information required to gain an understanding of how the fuel cell power unit might most effectively be integrated with the HVAC and sanitary water heating systems of the CNG Tower has not been provided. Some speculative analysis has been carried out to understand how more effective use of heat from the fuel cell system might be attained.

A simplified, possible flow diagram for the fuel cell system is shown in Figure B-1. Table B-1 presents material and energy balance computations based on this flow diagram. A temperature-heat, T-Q, diagram of Figure B-2 shows the various heat quantities transferred within the fuel cell system along with the temperatures at which the heat is supplied or accepted. And finally, Figure B-3 is a T-Q diagram representing a heat exchanger which delivers reject heat from the fuel cell stack to a heat transfer fluid (possibly hot, and perhaps pressurized, water) for delivery to the HVAC system of the building.

Fuel Processing. Methane fuel is preheated and processed to provide $\mathrm{H}_{2}$ for the cell. This processing is assumed to be steam reforming

$$
\mathrm{CH}_{4}+\mathrm{H}_{2} \mathrm{O}->\mathrm{CO}+3 \mathrm{H}_{2}
$$

which requires heating the $\mathrm{CH}_{4}$ and $\mathrm{H}_{2} \mathrm{O}$ to $1000{ }^{\circ} \mathrm{F}$ (or higher) and providing the heat of reaction at this temperature. Excess $\mathrm{H}_{2} \mathrm{O}$ is added (assumed to be 4 mols $\mathrm{H}_{2} \mathrm{O} / \mathrm{mol} \mathrm{CH}_{4}$ ), as required by the fuel cell, to reduce the $\mathrm{CO}$ and increase the $\mathrm{H}_{2}$ content of the reformed products by means of the water gas shift

$$
\mathrm{H}_{2} \mathrm{O}+\mathrm{CO}->\mathrm{H}_{2}+\mathrm{CO}_{2}
$$

Maintaining a relatively low temperature of the products, $1000{ }^{\circ} \mathrm{F}$, shifts the equilibrium toward $\mathrm{H}_{2}$ and $\mathrm{CO}_{2}$. In Figure B-1 the heat for processing the fuel is provided at $1000{ }^{\circ} \mathrm{F}$ by preheating a separate supply of $\mathrm{CH}_{4}$ and air to $1000{ }^{\circ} \mathrm{F}$, combining the two streams, and transferring the heat of combustion to the $\mathrm{CH}_{4}$ and $\mathrm{H}_{2} \mathrm{O}$ which provide reformed fuel stream to the fuel cell stacks.

Alternatively, heat for the fuel reforming reaction might be provided by combining and burning partially consumed fuel and air streams which leave the fuel cell and transferring the resulting heat to the input $\mathrm{CH}_{4}$ and $\mathrm{H}_{2} \mathrm{O}$ feed stream. Or the $\mathrm{CH}_{4}$ fuel stream might be processed by partial combustion, adding a substoichiometric quantity of air

$$
\mathrm{CH}_{4}+(1 / 2) \mathrm{O}_{2}+\left(2 \mathrm{~N}_{2}\right)->\mathrm{CO}+2 \mathrm{H}_{2}+\left(2 \mathrm{~N}_{2}\right)
$$




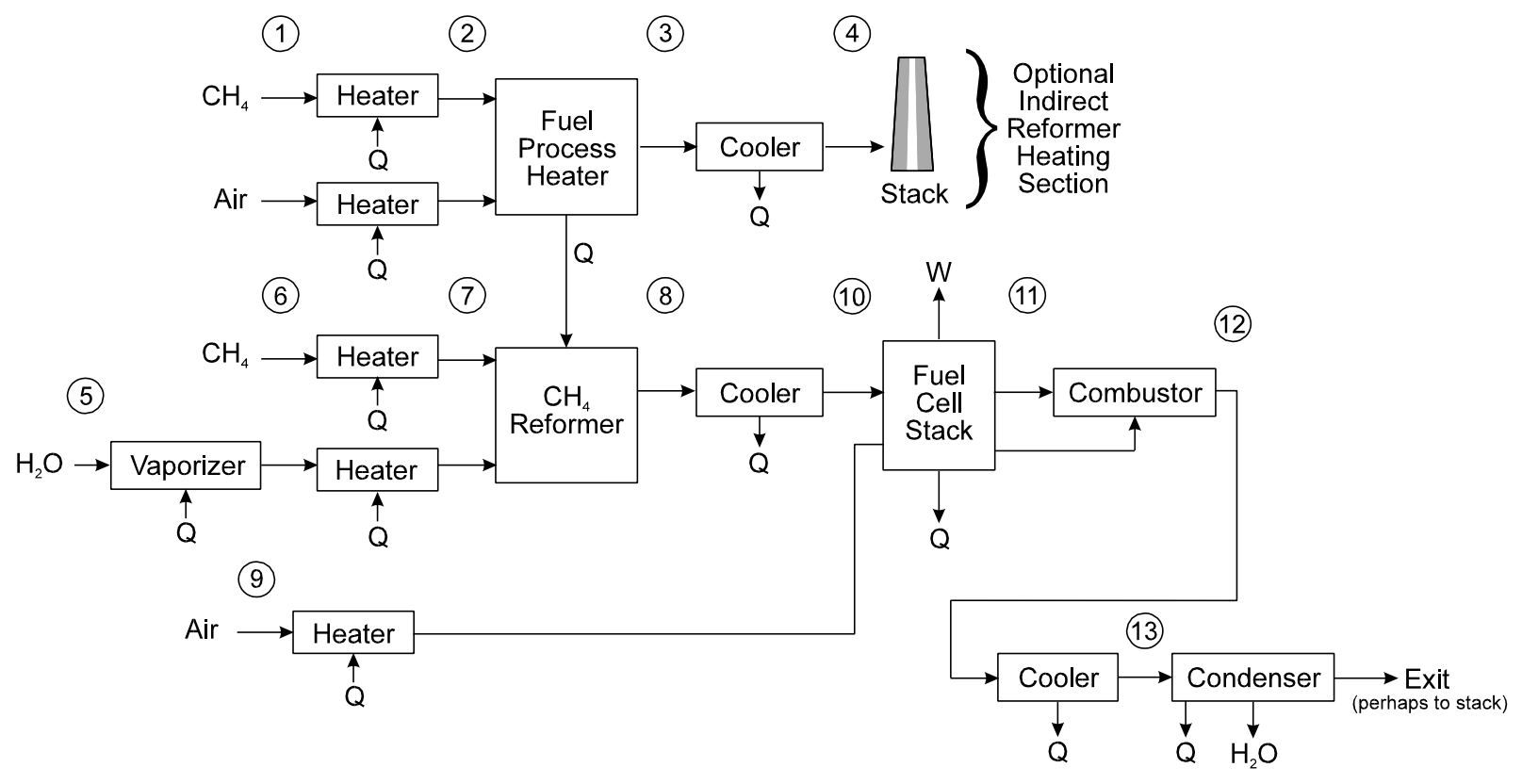

Figure B-1. Possible Fuel Cell Power System Flow Diagram With Heater, Cooler (Half Exchanger) Units

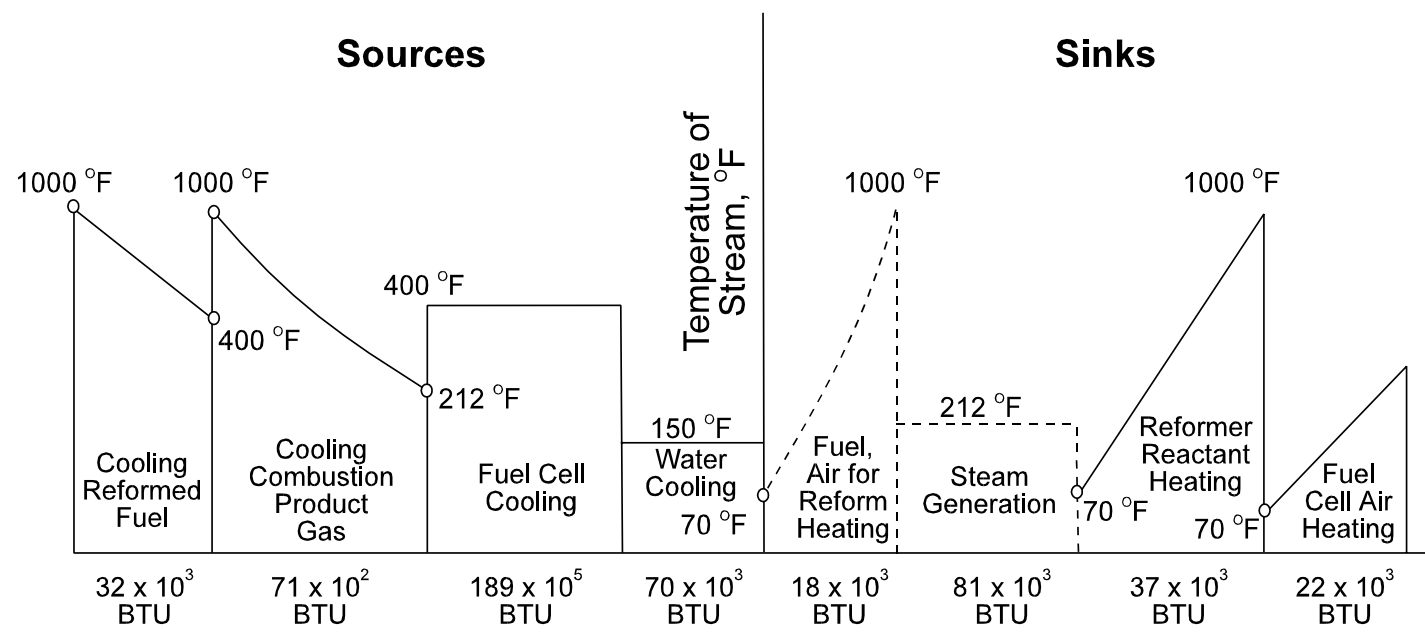

Heat Involved, BTU/lb mol $\mathrm{CH}^{4}$

Figure B-2. T-Q Diagram for Heat Sources and Sinks in the Fuel Cell Power System 
Table B-1: Low Temperature Fuel Cell Flow Diagram for External Methane Reforming Material and Energy Balances; CNG Tower, ONSI PC25C Fuel Cell System

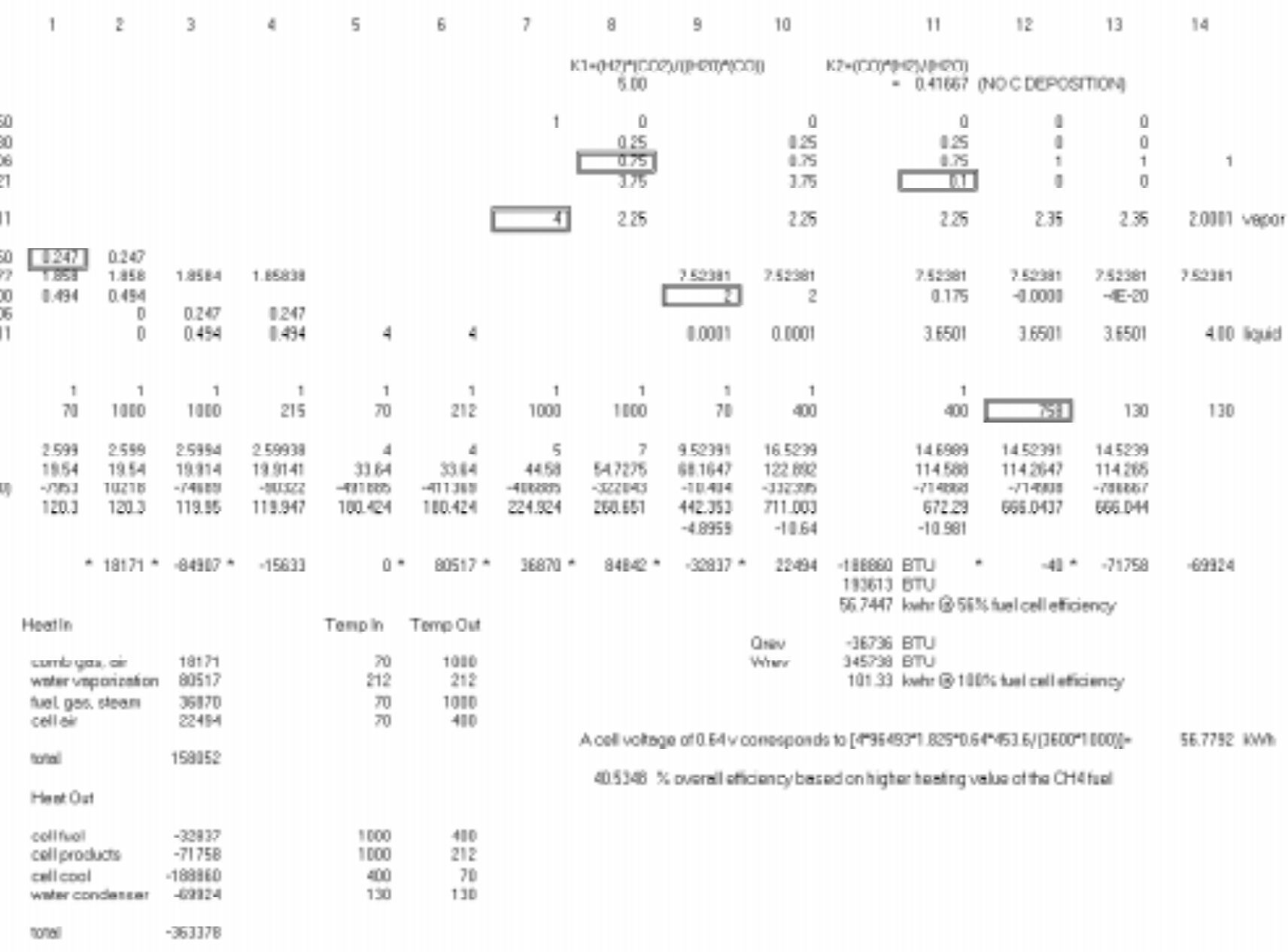

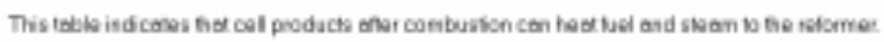

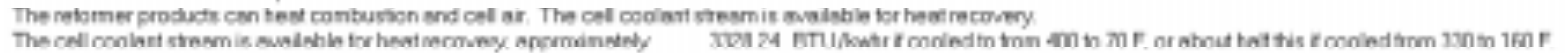




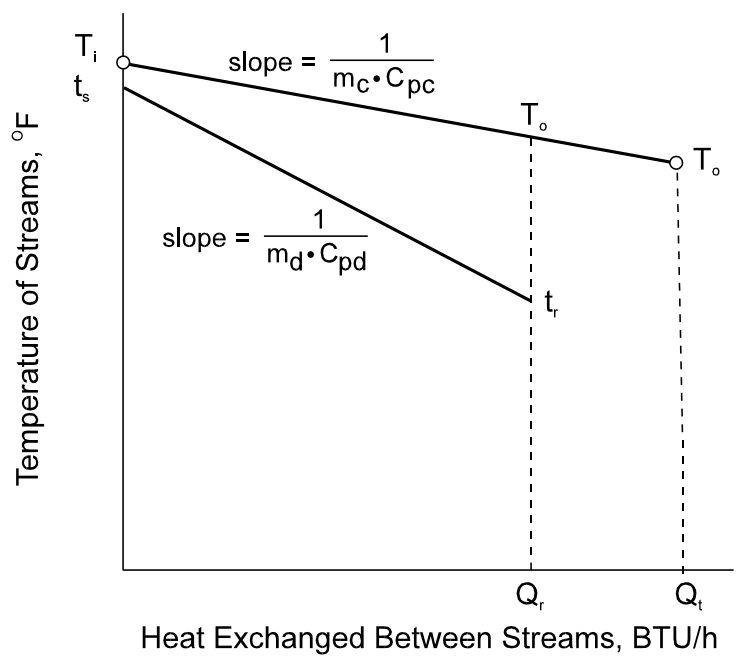

$Q_{t}=$ total heat rejected by the fuel cell stack
$Q_{r}=$ heat recovered
$Q_{t}-Q_{r}=$ heat to be dissipated
$T_{i}, T_{o}=$ fuel cell coolant exchanger inlet, outlet temperatures
$t_{s}, t_{r}=H V A C$ media supply and return temperatures
$m_{c}, m_{d}=$ flow rates of delivery and coolant media
$C_{p c}, C_{p d}=$ specific heats of delivery and coolant media

\section{Figure B-3. T-Q Diagram for Heat Exchange in the Heat Recovery Exchanger of the Fuel Cell Power System}

By adding a slight excess of air, the temperature necessary to carry out the reaction can be achieved; partial combustion, carried out; and the $\mathrm{CH}_{4}$ fuel, processed without additional heat. Again, $\mathrm{H}_{2} \mathrm{O}$ is added to decrease the $\mathrm{CO}$, to increase the $\mathrm{H}_{2}$, and to prevent solid $\mathrm{C}$ deposition by means of the gasification reaction

$$
\mathrm{C}+\mathrm{H}_{2} \mathrm{O}->\mathrm{CO}+\mathrm{H}_{2} \text {. }
$$

The $\mathrm{H}_{2} \mathrm{O}$ required for $\mathrm{CH}_{4}$ fuel processing, in any case, is provided by condensing and separating it from gaseous combustion products leaving the fuel cell system. Alternatively, a portion of the whole product stream might be recycled to provide the necessary $\mathrm{H}_{2} \mathrm{O}$ as a vapor. This measure would, however, result in a significant dilution of the fuel stream with $\mathrm{N}_{2}$ and in a greatly increased volume of fuel gas flowing through the fuel cell system.

The fuel gas -- in general a mixture of $\mathrm{H}_{2}, \mathrm{CO}, \mathrm{H}_{2} \mathrm{O}, \mathrm{CO}_{2}$, and perhaps $\mathrm{N}_{2}$ if partial combustion or product gas recycle is used in processing -- must then be cooled from the processing temperature to the fuel cell operating temperature to prevent overheating of the cells. Heat can be recovered from this cooling and also from cooling the products of combustion if the fuel reforming is externally heated. 
The choice of the $\mathrm{CH}_{4}$ processing reaction with its required temperature and the sources of heat and $\mathrm{H}_{2} \mathrm{O}$ for the process obviously affect the heat requirements of and availability from the overall fuel cell power system.

Fuel Cell Power Generation. $\mathrm{H}_{2}$ is transferred within the PAFC cell stack from the fuel to the air stream, both of which are adjusted in temperature prior to entering the cell in order to assist in maintaining it at a suitable operating temperature, approximately $400{ }^{\circ} \mathrm{F}$.

$$
\mathrm{H}_{2}+(1 / 2) \mathrm{O}_{2}+\left(2 \mathrm{~N}_{2}\right)->\mathrm{H}_{2} \mathrm{O}+\left(2 \mathrm{~N}_{2}\right)
$$

This process, carried out under near isothermal conditions in the cell, produces heat. And to the extent that the cell operates irreversibly, more heat is produced. This heat must be removed from the cell stack by means of

- A circulating coolant through heat transfer surface in the stack and

- A circulating or excess stream of air through the stack.

In either case, the heat removed from the stack must be recovered for use if cogeneration is an objective.

Most of the $\mathrm{H}_{2}$, but none of the $\mathrm{CO}$, in the fuel gas stream is consumed in the fuel cell stack. Residual $\mathrm{O}_{2}$ remains in the depleted air stream leaving through the cell stack. The presence of some $\mathrm{H}_{2}$ and $\mathrm{O}_{2}$ reactants in the exit streams is essential to maintain reasonable cell voltages throughout the stack.

Heat Recovery Exchanger. Heat recovery from operation of the fuel cell stack is accomplished in an exchanger through which the coolant or circulating air from the cell stack passes and transfers heat to a secondary stream which delivers the it to the HVAC system of the building. A T-Q diagram for this exchanger is represented in Figure B-3. The total flow of heat available from the operation of the fuel cell $(\mathrm{Qt}, \mathrm{Btu} / \mathrm{h})$ is fixed by the operating conditions of the stack -inlet fuel and air flows (compositions, temperatures, and pressures) -- cell stack voltage and current. The temperature of the cell coolant at the inlet to the exchanger (Ti, F) is limited by the maximum operating temperature of the cell. The temperature of the coolant at the outlet (To, F) is determined by its flow rate $(\mathrm{mc}, \mathrm{lb} / \mathrm{h})$ : the higher the flow, the less the difference between coolant inlet and outlet temperatures.

$$
\begin{aligned}
\mathrm{Qt}= & \mathrm{mc} * \mathrm{Cpc} *(\mathrm{Ti}-\mathrm{To}) \\
& \text { where } \mathrm{Cpc}=\text { the specific heat of the coolant, Btu/lb F }
\end{aligned}
$$

The recovery of heat in this exchanger and its delivery to the HVAC system of the building may be limited by the designated supply and return temperatures of the media for heat delivery, ts and $\mathrm{tr}$, and the area of the exchanger $\left(\mathrm{A}, \mathrm{ft}^{2}\right)$. This area is related to the heat recovered and delivered to the HVAC system, Qr (which may be < Qt), by 


$$
\begin{aligned}
\mathrm{Qr} & =\mathrm{UA}\left[(\mathrm{Ti}-\mathrm{ts})-\left(\mathrm{To}^{\prime}-\mathrm{tr}\right)\right] / \ln \left[(\mathrm{Ti}-\mathrm{ts}) /\left(\mathrm{To} \mathrm{o}^{\prime}-\mathrm{tr}\right)\right]=\mathrm{md}^{*} \mathrm{Cpd} *(\mathrm{ts}-\mathrm{tr}) \\
& =\mathrm{mc}^{*} \mathrm{Cpc} *\left(\mathrm{Ti}-\mathrm{To}^{\prime}\right)
\end{aligned}
$$

where $\quad U=$ the overall heat transfer coefficient between the cell coolant and HVAC delivery streams in the heat recovery exchanger.

T's, t's $=$ the temperatures indicated in the T-Q diagram, Figure B-3.

$\mathrm{md}=$ the flow rate of the delivery media to the HVAC system, lb/h.

$\mathrm{Cpd}=$ the specific heat of the delivery media, Btu/lb F.

If the quantities $\mathrm{U}, \mathrm{A}, \mathrm{Qt}, \mathrm{mc}, \mathrm{Cpc}$, and Ti are fixed in the design and operation of the fuel cell power system and if the quantities Cpd in the design of the HVAC system, then Qr, md, To, and To' can be calculated from the equations above if ts and tr are fixed. This analysis provides a possible basis for the ONSI chart of Figure 24; preliminary calculations indicate that the form of the curves is predicted by this analysis.

The analysis indicates why the heat recovered and delivered to the HVAC, Qr, may be less than that available from cell stack operation, $\mathrm{Qh}$; and it points out that modifications in the design and operation of both the fuel cell and the HVAC system (changes in U, A, mc, ts, and tr) may be required to minimize this difference and thus to maximize heat recovery and to minimize heat which must be dissipated to the surroundings.

Combustor. The exit fuel gas and air streams from the fuel cell are combined in the combustor where unreacted $\mathrm{H}_{2}$ and $\mathrm{CO}$ combine with $\mathrm{O}_{2}$ to form combustion products and release heat in the exit gas.

Heat Interchangers. Exchangers are included in the system to adjust as necessary the temperature of streams flowing in the fuel cell system and to recover and utilize the associated heat

- To preheat input $\mathrm{CH}_{4}$ and air streams.

- To vaporize and preheat the $\mathrm{H}_{2} \mathrm{O}$ input stream.

- To cool the fuel gas leaving the fuel processing unit entering the fuel cell stack.

- To cool the exit stream from the combustor and to condense and recover the $\mathrm{H}_{2} \mathrm{O}$ required or fuel processing.

The T-Q diagram of Figure B-2 aids in determining how to couple heat sources and sinks appropriately in terms of the quantities and temperatures of the heat to be exchanged. 


\section{Appendix C. Generalized Design Procedure for Building Cogeneration Design, and Performance Evaluation}

A generalized system design and performance evaluation procedure for a building cogeneration system, based on this specific study of a PAFC cogeneration system for the CNG Tower, follows:

- Determine power demand curves weekdays, Saturdays, and Sundays.

- Determine heating requirements, heat rate in, daily (perhaps also hourly) as a function of average ambient temperature, interior thermostat setting, building occupancy, and ventilation system operation (fresh air flow).

- Estimate heat requirements for sanitary hot water.

- Determine air conditioning requirements, heat rate out, daily (perhaps also hourly) as a function of average ambient temperature and humidity, interior thermostat setting, building occupancy, ventilation system operation (fresh air flow).

- Establish from meteorological data the expected distribution of building ambient temperature and humidity. Establish desired range of conformance with thermostat setting over the expected range of ambient conditions.

- Determine the performance characteristics of the fuel cell cogeneration system over its load range: the generation efficiency; the reject heat quantity and quality (temperature) over the electrical load range; the equipment, installation, and maintenance costs; and the system availability.

- Select all the components and designate their capacity for the overall cogeneration-HVAC system of the building. Give particular attention to the integration of the heat rejection equipment of the fuel cell cogeneration unit with the HVAC heating and air conditioning and the hot water supply equipment of the building. Consider also in detail the integrated control system for the power supply and the HVAC systems of the building.

- Determine fuel costs; the costs and benefits of various possible arrangements with the local electric utility -- power purchase and sale, emergency and backup power supply.

- Describe the system and its operation; evaluate the performance (calculate natural gas fuel usage, net power purchase-sale costs, system capital and operating costs) of the overall cogeneration-HVAC system of the building for the expected range of ambient conditions.

- Determine impact of the cogeneration system on the environment and evaluate its overall benefits relative to purchase of power and fuel from electric and gas utilities. And if the results appear attractive -- 
- Prepare a layout of the cogeneration system equipment and auxiliaries in the building, carry out detailed design and costing of the system considering particularly its interfaces with the building electrical and HVAC systems including their controls.

This overall procedure will obviously depend on whether:

- The building is an existing one in which measurements of power and natural gas use and air conditioning operation can be obtained.

- The building is in design so that power and natural gas use and air conditioning operation can only be estimated based on its design features and location (including its orientation and the various weather factors) -- perhaps based on a computer model of the building such as DOE-2.

Future work should consider alternative HVAC systems and additional cogeneration technologies and modes of system operation, including those which involve selling excess power or storing thermal and electrical energy. 


\section{Appendix D. Detailed Description of System Performance Modeling}

System Modeling. The performance of a total of six systems -- the existing system and five fuel cell cogeneration systems -- were modeled as they operated to meet the CNG Tower's energy needs for the year 1993:

1. The CNG Tower's existing system,

2. A 600-kW base load fuel cell system without an absorption chiller.

3.-4. A 1500-kW average load fuel cell/battery storage system with and without an absorption chiller.

5.-6. A peak load capacity PAFC cogeneration system with, $2700 \mathrm{~kW}$, and without, $2800 \mathrm{~kW}$, an absorption chiller.

Tables 4 and 5 summarize how these systems were modeled.

Data from the CNG Tower's automated HVAC system were used to characterize the building's demands for electricity, space heating, and air conditioning throughout the year 1993. Thirty-three days in three categories -- weekdays, 17; Sundays, 8; and Saturdays, 8 -- were sampled for detailed analysis. For each of these 33 days, the following raw data was analyzed: hourly electric demands, ${ }^{10}$ hourly air conditioning demands ${ }^{10}$ and daily space heating demands . Based on the analyses of these 33 days, correlations were developed which could be used to model the CNG Tower's demands for electricity, space heating, and air conditioning throughout the entire year of 1993.

Characterization of Non-Air Conditioning Electricity Demand. Since the CNG Tower's non-air conditioning hourly electricity demand profiles varied only by the day of the week, and not seasonally, it was concluded that an entire year could be accurately modeled by substituting the three averaged non-air conditioning hourly electricity demand profiles for each weekday, Sunday, and Saturday. See the discussion in Section 2.2 and Figures 10, 11, and 12.

Calculation of Total Electricity Demand. For days which do not require air conditioning beyond that provided by the cooling tower heat exchanger, the total hourly electricity demand is equivalent to the non-air conditioning hourly electricity demand (see above). Otherwise, the amounts of electricity used by the electric chiller, $0.79 \mathrm{~kW} /$ ton, and absorption chiller, $0.15 \mathrm{~kW} /$ ton, were added to the non-air conditioning totals to calculate the CNG Tower's total hourly electricity demand.

Correlation for Monthly Peak of Electric Utility Power. For the systems which rely on the electric utility for all or part of the required electricity, the peak monthly electric demand must be

${ }^{10}$ Average demand during the hour. 
identified to calculate the utility's demand charges. The peak daily electric demand (i.e., the maximum hourly demand ${ }^{11}$ ), including any power used for air conditioning, of the CNG Tower's existing system was identified for each of the 17 weekdays, 8 Sundays, and 8 Saturdays. These daily "peak" demands were then correlated to daily weather data. ${ }^{12}$ For each category (weekday, Sunday, and Saturday), a distinct correlation was computed to relate the peak electric demand to the average daily relative humidity and the average daily temperature. With this correlation, the daily peak for the existing system was calculated for each day of the year, based on 1993 Weather Bureau data. The 12 monthly peaks were then identified as each month's maximum daily peak.

Since the peak load fuel cell systems do not rely on the utility for any power, they do not require the calculation of a monthly peak. However, the peak monthly power supplied by the utility to the base and average load fuel cell systems must be calculated. Since the fuel cell in the base load system operates at constant output, the monthly utility peaks were calculated by simply subtracting the fuel cell capacity from each monthly utility peak for the existing system. Similarly, the monthly utility peaks for the average load systems were calculated by subtracting the sum of the fuel cell capacity and the battery capacity from each monthly utility peak for the existing system. Furthermore, since nearly all the monthly peaks occur when the chillers are operating, the monthly peaks are reduced by the differential power required by the absorption chiller operating at full capacity and an electric chiller of equivalent size.

Air Conditioning and Space Heating Correlations. The total daily air conditioning and the total daily gas usage for space heating were calculated for each of 17 weekdays, 8 Sundays and 8 Saturdays. These daily totals were then correlated to daily weather data from the Weather Bureau. For each category (weekday, Sunday, and Saturday), a distinct correlation was computed to relate the total daily tons of air conditioning to the average daily relative humidity and the average daily temperature. See discussion in Section 2.2 and Figures 18a and 18b. A single correlation was found to accurately relate the total daily gas usage for space heating on weekdays, Sundays, and Saturdays with the average daily temperature alone. See discussion in Section 2.2 and Figure 14.

Calculation of Air Conditioning Produced by the Absorption Chiller. Since the fuel cell cogeneration system does not include any significant thermal storage capacity, the absorption chiller must utilize heat as it is rejected from the fuel cell. As discussed in Section 3.2, the integration of the fuel cell and absorption chiller was modeled on an hourly basis for both the peak and average load fuel cell systems. For each system, the resulting data was categorized into two groups, weekdays and weekends. See Figures 25-28. The equations which fit the data, described in Section 3.2, were used to calculate the daily amount of air conditioning supplied by the

${ }^{11}$ The utility identifies peak demand as the maximum rolling 15-minute average. Although the maximum nonrolling hourly average is used here, the error is considered negligible, especially since any comparisons are based on the same methodology.

${ }^{12}$ Weather data measured at the Greater Pittsburgh Airport was obtained from the Weather Bureau. Although temperatures at the Greater Pittsburgh Airport are, on average, $4{ }^{\circ} \mathrm{F}$ lower than those in downtown Pittsburgh, this difference was negligible for this analysis. 
absorption chiller as a function of total daily air conditioning demand. Any deficit in the required amount of daily air conditioning is assumed to be accomplished by the electric chillers.

Calculation of Space Heating Supplied by Fuel Cell Waste Heat. Integration of the fuel cell and the space heating system was modeled on a daily basis since only daily, and not hourly, space heating demand data was available. It is recognized that this approach cannot ascertain the extent to which the hourly fuel cell heat rejection matches the hourly space heating demand. The total daily space heating requirements were calculated using the correlation described in Section 2.2 and illustrated in Figures 14 and 19.

For each category (weekday, Sunday, and Saturday), the total daily fuel cell heat rejection was calculated based on the corresponding average non-air conditioning electrical load profile. For a given day, the total daily fuel cell heat rejection, less any heat used by the absorption chiller during the day, was subtracted from the total required daily space heating. A positive balance indicated the need for supplementary heat, which would be supplied by the natural gas boiler. A zero or negative balance indicated that the heat rejected by the fuel cell was sufficient for the required space heating. The amount of reject heat that could be practically used for space heating is exaggerated by this approach since it assumes that all the heat rejected throughout the day is somehow stored and available whenever it is needed by the space heating system. However, the magnitude of this error is small for two reasons: (1) much of the fuel cell heat would be used for space heating immediately as it is rejected and would not require storage, and (2) the CNG Tower itself provides significant thermal storage capacity. 
Table D-1. Modeling Equations for Daily Calculations Without an Absorption Chiller

\begin{tabular}{|c|c|c|c|c|}
\hline & Existing System & Base Load System & Average Load System & Peak Load System \\
\hline $\begin{array}{l}\text { Non-A.C. kWh Con- } \\
\text { sumed During Day, A }\end{array}$ & \multicolumn{4}{|c|}{$\begin{array}{l}\text { Calculated from load following the three averaged non-a.c. electric demand profiles: } \\
\qquad \begin{array}{c}A_{\mathrm{wkdy}}=33848 \\
\mathrm{~A}_{\mathrm{Sun}}=17958 \\
\mathrm{~A}_{\mathrm{Sat}}=21303\end{array}\end{array}$} \\
\hline $\begin{array}{l}\text { Ton-Hrs Air Condi- } \\
\text { tioning Required During } \\
\text { Day, B }\end{array}$ & \multicolumn{4}{|c|}{$\begin{aligned} \mathrm{B}_{\text {wkdy }} & =291 \mathrm{~T}_{\text {avg }}+65.2 \mathrm{H}_{\text {avg }}-18100 \\
\mathrm{~B}_{\text {Sun }} & =203 \mathrm{~T}_{\text {avg }}+103 \mathrm{H}_{\text {avg }}-19900 \\
\mathrm{~B}_{\text {Sat }} & =282 \mathrm{~T}_{\text {avg }}+113 \mathrm{H}_{\text {avg }}-24500\end{aligned}$} \\
\hline $\begin{array}{l}\text { Ton-Hrs Air Condi- } \\
\text { tioning by Electric } \\
\text { Chiller During Day, D }\end{array}$ & \multicolumn{4}{|c|}{$\begin{aligned} D_{\text {wkdy }} & =B_{\text {wkdy }} \\
D_{\text {Sun }} & =B_{\text {Sun }} \\
D_{\text {Sat }} & =B_{\text {Sat }}\end{aligned}$} \\
\hline $\begin{array}{l}\text { Total kWh Consumed } \\
\text { During Day, E }\end{array}$ & \multicolumn{4}{|c|}{$\begin{aligned} \mathrm{E}_{\mathrm{wkdy}} & =\mathrm{A}_{\mathrm{wkdy}}+0.79 \mathrm{D}_{\mathrm{wkdy}} \\
\mathrm{E}_{\text {Sun }} & =\mathrm{A}_{\text {Sun }}+0.79 \mathrm{D}_{\text {Sun }} \\
\mathrm{E}_{\text {Sat }} & =\mathrm{A}_{\text {Sat }}+0.79 \mathrm{D}_{\text {Sat }}\end{aligned}$} \\
\hline $\begin{array}{l}\mathrm{kWh} \text { Generated by Fuel } \\
\text { Cell During Day, } \mathbf{F}\end{array}$ & N/A & $\begin{array}{l}\text { Calculated from the fuel } \\
\text { cell's load following (to } \\
\text { the extent possible) of the } \\
\text { three averaged non-a.c. } \\
\text { electric demand profiles: } \\
\mathrm{F}_{\text {wkdy }}=14344 \\
\mathrm{~F}_{\text {Sun }}=14283 \\
\mathrm{~F}_{\text {Sat }}=14400\end{array}$ & $\begin{array}{l}\text { Due to battery inefficiencies, } \\
\text { the average load system } \\
\text { generates slightly more than } \\
\text { the average non-a.c. week- } \\
\text { day load: } \\
\mathrm{F}_{\text {wkdy }}=35376 \\
\text { All power, including that } \\
\text { used for a.c., is supplied by } \\
\text { the fuel cell on weekends, } \\
\text { although battery storage } \\
\text { penalties are only realized } \\
\text { for the a.c. portion. } \\
\mathrm{F}_{\text {Sun }}=\mathrm{A}_{\text {Sun }}+0.79 \mathrm{D}_{\text {Sun }} / 0.78 \\
\mathrm{~F}_{\text {Sat }}=\mathrm{A}_{\text {Sat }}+0.79 \mathrm{D}_{\text {Sat }} / 0.78\end{array}$ & $\begin{aligned} \mathrm{F}_{\mathrm{wkdy}} & =\mathrm{E}_{\mathrm{wkdy}} \\
\mathrm{F}_{\text {Sun }} & =\mathrm{E}_{\text {Sun }} \\
\mathrm{F}_{\text {Sat }} & =\mathrm{E}_{\text {Sat }}\end{aligned}$ \\
\hline $\begin{array}{l}\text { MCF of Gas Consumed } \\
\text { by Fuel Cell During } \\
\text { Day, G }\end{array}$ & N/A & \multicolumn{3}{|c|}{ 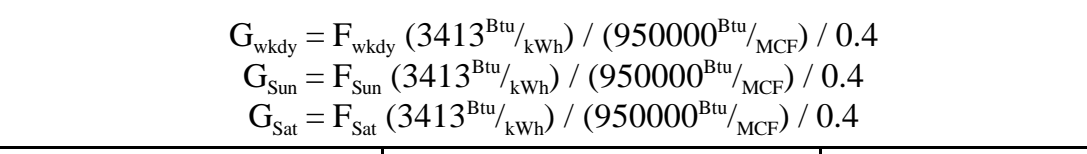 } \\
\hline $\begin{array}{l}\text { kWh Provided by Utility } \\
\text { During Day, } \mathbf{H}\end{array}$ & $\begin{aligned} \mathrm{H}_{\text {wkdy }} & =\mathrm{E}_{\mathrm{wkdy}} \\
\mathrm{H}_{\text {Sun }} & =\mathrm{E}_{\text {Sun }} \\
\mathrm{H}_{\text {Sat }} & =\mathrm{E}_{\text {Sat }}\end{aligned}$ & $\begin{array}{c}\mathrm{H}_{\text {wkdy }}=\mathrm{E}_{\text {wkdy }}-\mathrm{F}_{\text {wkdy }} \\
\mathrm{H}_{\text {Sun }}=\mathrm{E}_{\text {Sun }}-\mathrm{F}_{\text {Sun }} \\
\mathrm{H}_{\text {Sat }}=\mathrm{E}_{\text {Sat }}-\mathrm{F}_{\text {Sat }}\end{array}$ & $\begin{array}{c}\mathrm{H}_{\text {wkdy }}=0.79 \mathrm{D}_{\text {wkdy }} \\
\mathrm{H}_{\text {Sun }}=0 \\
\mathrm{H}_{\text {Sat }}=0\end{array}$ & $\begin{aligned} \mathrm{H}_{\text {wkdy }} & =0 \\
\mathrm{H}_{\text {Sun }} & =0 \\
\mathrm{H}_{\text {Sat }} & =0\end{aligned}$ \\
\hline $\begin{array}{l}\text { Fuel Cell Capacity } \\
(\mathrm{kW}), \mathbf{I}\end{array}$ & N/A & $\mathrm{I}=600$ & $\mathrm{I}=1500$ & $\mathrm{I}=2800$ \\
\hline $\begin{array}{l}\text { Peak Demand for Utility } \\
\text { kW During Day, } \mathbf{J}\end{array}$ & $\begin{array}{c}\mathrm{J}_{\text {wkdy }}=15.9 \mathrm{~T}_{\text {avg }}+ \\
5.07 \mathrm{H}_{\text {avg }}+997 \\
\mathrm{~J}_{\text {Sun }}=26.4 \mathrm{~T}_{\text {avg }}+ \\
14.4 \mathrm{H}_{\text {avg }}-1730 \\
\mathrm{~J}_{\text {Sat }}=17.0 \mathrm{~T}_{\text {avg }}+ \\
5.27 \mathrm{H}_{\text {avg }}-17.5\end{array}$ & $\begin{array}{l}\mathrm{J}_{\text {wkdy }}=\left(\mathrm{J}_{\text {wkdy }}\right)_{\text {Existing System }}-\mathrm{I} \\
\mathrm{J}_{\text {Sun }}=\left(\mathrm{J}_{\text {Suu }}\right)_{\text {Existing System }}-\mathrm{I} \\
\mathrm{J}_{\text {Sat }}=\left(\mathrm{J}_{\text {Sat }}\right)_{\text {Existing System }}-\mathrm{I}\end{array}$ & $\begin{array}{l}\mathbf{J}_{\text {wkdy }}=\left(\mathbf{J}_{\text {wkdy }}\right)_{\text {Existing System }}-\mathbf{I}-\mathbf{P} \\
\mathrm{J}_{\text {Sun }}=\left(\mathbf{J}_{\text {Sun }}\right)_{\text {Existing System }}-\mathbf{I}-\mathbf{P} \\
\mathrm{J}_{\text {Sat }}=\left(\mathrm{J}_{\text {Sat }}\right)_{\text {Existing System }}-\mathrm{I}-\mathrm{P}\end{array}$ & $\begin{aligned} \mathrm{J}_{\mathrm{wkdy}} & =0 \\
\mathrm{~J}_{\text {Sun }} & =0 \\
\mathrm{~J}_{\text {Sat }} & =0\end{aligned}$ \\
\hline
\end{tabular}


Table D-1. Modeling Equations for Daily Calculations Without an Absorption Chiller (Continued)

\begin{tabular}{|c|c|c|c|c|}
\hline & Existing System & Base Load System & Average Load System & Peak Load System \\
\hline $\begin{array}{l}\text { Ton-Hrs Space Heating } \\
\text { Required During Day, } \\
\mathbf{K}\end{array}$ & \multicolumn{4}{|c|}{$\mathrm{K}=\left(-3.1 \mathrm{~T}_{\mathrm{avg}}+173\right)(0.88)(950000) /(12000)$} \\
\hline \multirow{2}{*}{$\begin{array}{l}\text { Ton-Hrs Heat at } 250^{\circ} \mathrm{F} \\
\text { Rejected by Fuel Cell } \\
\text { Available for Space } \\
\text { Heating, } \mathbf{L}\end{array}$} & \multirow[t]{2}{*}{ N/A } & \multicolumn{3}{|c|}{$\begin{array}{l}\text { See Table 1. Calculated from the fuel cell's load following (to the extent } \\
\text { possible) of the three averaged non-a.c. electric demand profiles: }\end{array}$} \\
\hline & & $\begin{array}{l}\mathrm{L}_{\text {wkdy }}=2084 \\
\mathrm{~L}_{\text {Sun }}=2066 \\
\mathrm{~L}_{\text {Sat }}=2100\end{array}$ & $\begin{array}{c}\mathrm{L}_{\text {wkdy }}=5159 \\
\mathrm{~L}_{\text {Sun }}=425 \\
\mathrm{~L}_{\text {Sat }}=1108\end{array}$ & $\begin{array}{c}\mathrm{L}_{\mathrm{wkdy}}=2014 \\
\mathrm{~L}_{\mathrm{Sun}}=0 \\
\mathrm{~L}_{\mathrm{Sat}}=0\end{array}$ \\
\hline $\begin{array}{l}\text { Ton-Hrs Space Heating } \\
\text { Provided by Natural } \\
\text { Gas-Fired Boiler, } \mathbf{M} \\
\end{array}$ & $\mathrm{M}=\mathrm{K}$ & \multicolumn{3}{|c|}{$\begin{aligned} \mathrm{M}_{\text {wkdy }} & =\mathrm{K}-\mathrm{L}_{\mathrm{wkdy}} \\
\mathrm{M}_{\text {Sun }} & =\mathrm{K}-\mathrm{L}_{\text {Sun }} \\
\mathrm{M}_{\text {Sat }} & =\mathrm{K}-\mathrm{L}_{\text {Sat }}\end{aligned}$} \\
\hline $\begin{array}{l}\text { kW Capacity of Battery, } \\
\mathbf{P}\end{array}$ & N/A & N/A & $P=568$ & N/A \\
\hline
\end{tabular}




\section{Table D-2. Modeling Equations for Daily Calculations for Systems With an Absorption Chiller}

\begin{tabular}{|c|c|c|}
\hline & Average Load System & Peak Load System \\
\hline Non-A.C. kWh Consumed During Day, A & \multicolumn{2}{|c|}{ 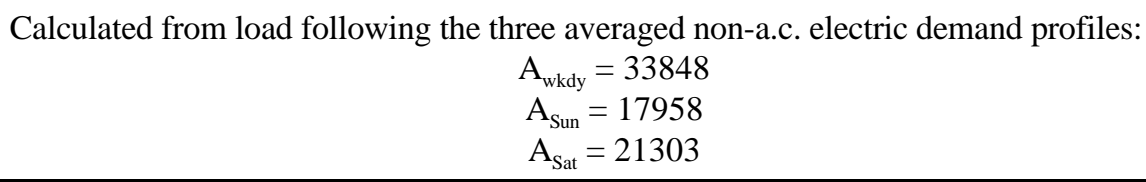 } \\
\hline $\begin{array}{l}\text { Ton-Hrs Air Conditioning Required } \\
\text { During Day, B }\end{array}$ & \multicolumn{2}{|c|}{$\begin{aligned} \mathrm{B}_{\text {wkdy }} & =291 \mathrm{~T}_{\text {avg }}+65.2 \mathrm{H}_{\text {avg }}-18100 \\
\mathrm{~B}_{\text {Sun }} & =203 \mathrm{~T}_{\text {avg }}+103 \mathrm{H}_{\text {avg }}-19900 \\
\mathrm{~B}_{\text {Sat }} & =282 \mathrm{~T}_{\text {avg }}+113 \mathrm{H}_{\text {avg }}-24500\end{aligned}$} \\
\hline $\begin{array}{l}\text { Ton-Hrs Air Conditioning by Absorption } \\
\text { Chiller During Day, } \mathbf{C}\end{array}$ & 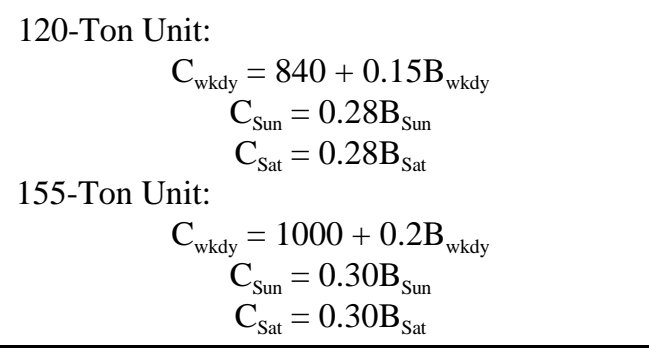 & $\begin{array}{l}\text { 120-Ton Unit: } \\
\text { C }_{\mathrm{wkdy}}=830+0.08 \mathrm{~B}_{\mathrm{wkdy}} \\
\mathrm{C}_{\text {Sun }}=0.04 \mathrm{~B}_{\text {Sun }} \\
\mathrm{C}_{\text {Sat }}=0.04 \mathrm{~B}_{\text {Sat }} \\
\text { 205-Ton Unit: } \\
\mathrm{C}_{\mathrm{wkdy}}=900+0.16 \mathrm{~B}_{\mathrm{wkdy}} \\
\mathrm{C}_{\text {Sun }}=0.04 \mathrm{~B}_{\text {Sun }} \\
\mathrm{C}_{\text {Sat }}=0.04 \mathrm{~B}_{\text {Sat }}\end{array}$ \\
\hline $\begin{array}{l}\text { Ton-Hrs Air Conditioning by Electric } \\
\text { Chiller During Day, D }\end{array}$ & \multicolumn{2}{|c|}{$\begin{aligned} \mathrm{D}_{\text {wkdy }} & =\mathrm{B}_{\mathrm{wkdy}}-\mathrm{C}_{\mathrm{wkdy}} \\
\mathrm{D}_{\text {Sun }} & =\mathrm{B}_{\text {Sun }}-\mathrm{C}_{\text {Sun }} \\
\mathrm{D}_{\text {Sat }} & =\mathrm{B}_{\text {Sat }}-\mathrm{C}_{\text {Sat }}\end{aligned}$} \\
\hline Total kWh Consumed During Day, $\mathbf{E}$ & \multicolumn{2}{|c|}{$\begin{array}{c}\mathrm{E}_{\mathrm{wkdy}}=\mathrm{A}_{\mathrm{wkdy}}+0.15 \mathrm{C}_{\mathrm{wkdy}}+0.79 \mathrm{D}_{\text {wkdy }} \\
\mathrm{E}_{\text {Sun }}=\mathrm{A}_{\text {Sun }}+0.15 \mathrm{C}_{\text {Sun }}+0.79 \mathrm{D}_{\text {Sun }} \\
\mathrm{E}_{\text {Sat }}=\mathrm{A}_{\text {Sat }}+0.15 \mathrm{C}_{\text {Sat }}+0.79 \mathrm{D}_{\text {Sat }}\end{array}$} \\
\hline $\begin{array}{l}\text { kWh Generated by Fuel Cell During Day, } \\
\text { F }\end{array}$ & $\begin{array}{l}\text { Due to battery inefficiencies, the average load } \\
\text { system generates slightly more than the } \\
\text { average non-a.c. weekday load: } \\
\qquad \mathrm{F}_{\text {wkdy }}=35376 \\
\text { All power, including that used for a.c., is } \\
\text { supplied by the fuel cell on weekends, } \\
\text { although battery storage penalties are only } \\
\text { realized for the a.c. portion. } \\
\mathrm{F}_{\text {Sun }}=\mathrm{A}_{\mathrm{Sun}}+\left(0.15 \mathrm{C}_{\mathrm{Sun}}+0.79 \mathrm{D}_{\mathrm{Sun}}\right) / 0.78 \\
\mathrm{~F}_{\mathrm{Sat}}=\mathrm{A}_{\mathrm{Sat}}+\left(0.15 \mathrm{C}_{\mathrm{Sat}}+0.79 \mathrm{D}_{\mathrm{Sat}}\right) / 0.78 \\
\end{array}$ & $\begin{aligned} \mathrm{F}_{\mathrm{wkdy}} & =\mathrm{E}_{\mathrm{wkdy}} \\
\mathrm{F}_{\text {Sun }} & =\mathrm{E}_{\text {Sun }} \\
\mathrm{F}_{\text {Sat }} & =\mathrm{E}_{\text {Sat }}\end{aligned}$ \\
\hline $\begin{array}{l}\text { MCF of Gas Consumed by Fuel Cell } \\
\text { During Day, } \mathbf{G}\end{array}$ & \multicolumn{2}{|c|}{ 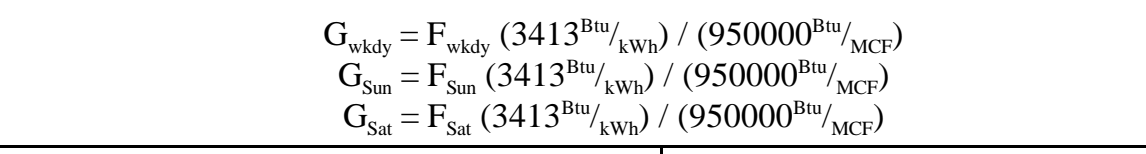 } \\
\hline kWh Provided by Utility During Day, $\mathbf{H}$ & $\begin{array}{l}\mathrm{H}_{\mathrm{wkdy}}=\mathrm{E}_{\mathrm{wkdy}}-33848 \\
\mathrm{H}_{\text {Sun }}=0 \\
\mathrm{H}_{\text {Sat }}=0\end{array}$ & N/A \\
\hline kW Fuel Cell Capacity, I & 1500 & 2700 \\
\hline $\begin{array}{l}\text { Peak Demand for Utility kW During Day, } \\
\text { J }\end{array}$ & $\begin{array}{l}\mathrm{J}_{\text {wkdy }}=\left(\mathrm{J}_{\text {wkdy }}\right)_{\text {Existing System }}-\mathrm{I}-\mathrm{P}-(0.79-0.15) \mathrm{N} \\
\mathrm{J}_{\text {Sun }}=\left(\mathrm{J}_{\text {Sun }}\right)_{\text {Existing System }}-\mathrm{I}-\mathrm{P}-(0.79-0.15) \mathrm{N} \\
\mathrm{J}_{\text {Sat }}=\left(\mathrm{J}_{\text {Sat }}\right)_{\text {Existing System }}-\mathrm{I}-\mathrm{P}-(0.79-0.15) \mathrm{N}\end{array}$ & N/A \\
\hline
\end{tabular}




\section{Table D-2. Modeling Equations for Daily Calculations for Systems With an Absorption Chiller}

(Continued)

\begin{tabular}{|c|c|c|}
\hline & Average Load System & Peak Load System \\
\hline $\begin{array}{l}\text { Ton-Hrs Space Heating Required During } \\
\text { Day, K }\end{array}$ & \multicolumn{2}{|c|}{$\mathrm{K}=\left(-3.1 \mathrm{~T}_{\text {avg }}+173\right)(0.88)(950000) /(12000)$} \\
\hline \multirow[t]{2}{*}{$\begin{array}{l}\text { Ton-Hrs Heat at } 250^{\circ} \mathrm{F} \text { Rejected by Fuel } \\
\text { Cell Available for Space Heating, } \mathbf{L}\end{array}$} & \multicolumn{2}{|c|}{$\begin{array}{l}\text { Calculated from the fuel cell's load following (to the extent possible) of the three } \\
\text { averaged non-a.c. electric demand profiles and subtracting the heat used by the } \\
\text { absorption chiller: }\end{array}$} \\
\hline & $\begin{aligned} \mathrm{L}_{\mathrm{wkdy}} & =3128-\mathrm{C}_{\mathrm{wkdy}} / 0.7 \\
\mathrm{~L}_{\mathrm{Sun}} & =1072-\mathrm{C}_{\mathrm{Suu}} / 0.7 \\
\mathrm{~L}_{\mathrm{Sat}} & =1978-\mathrm{C}_{\mathrm{Sat}} / 0.7\end{aligned}$ & $\begin{aligned} \mathrm{L}_{\mathrm{wkdy}}=2014-\mathrm{C}_{\mathrm{wkdy}} / 0.7 \\
\mathrm{~L}_{\mathrm{Sun}}=0 \\
\mathrm{~L}_{\mathrm{Sat}}=0\end{aligned}$ \\
\hline $\begin{array}{l}\text { Ton-Hrs Space Heating Provided by } \\
\text { Natural Gas-Fired Boiler, } \mathbf{M}\end{array}$ & \multicolumn{2}{|c|}{$\begin{aligned} \mathrm{M}_{\mathrm{wkdy}} & =\mathrm{K}-\mathrm{L}_{\mathrm{wkdy}} \\
\mathrm{M}_{\text {Sun }} & =\mathrm{K}-\mathrm{L}_{\text {Sun }} \\
\mathrm{M}_{\text {Sat }} & =\mathrm{K}-\mathrm{L}_{\text {Sat }}\end{aligned}$} \\
\hline Ton-Hrs Capacity of Absorption Chiller, $\mathbf{N}$ & 120 or 155 & 120 or 205 \\
\hline kW Capacity of Battery, $\mathbf{P}$ & 568 & N/A \\
\hline
\end{tabular}

